\title{
EFEITOS DO CALCÁRIO E GESSO NO SOLO E NA PRODUTIVIDADE DA LARANJEIRA HAMLIN (Citrus sinnensis L. Osbeck) SOBRE LIMOEIRO CRAVO (Citrus limonia L. Osbeck)
}

\author{
SEBASTIÃO ALVES DE LIMA FILHO \\ Engenheiro Agrônomo
}

Orientador: Prof. Dr. GODOFREDO CESAR VITTI

Tese apresentada à Escola Superior de Agricultura "Luiz de Queiroz", da Universidade de São Paulo, para obtenção do título de Doutor em Agronomia, Área de Concentração:

Solos e Nutrição de Plantas.

P IR A C I C A B A

Estado de São Paulo - Brasil

Maio - 1995 
CATALUGAGAO NA FULLILAGHU

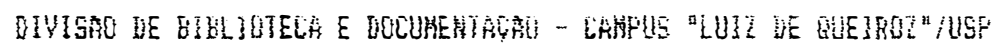

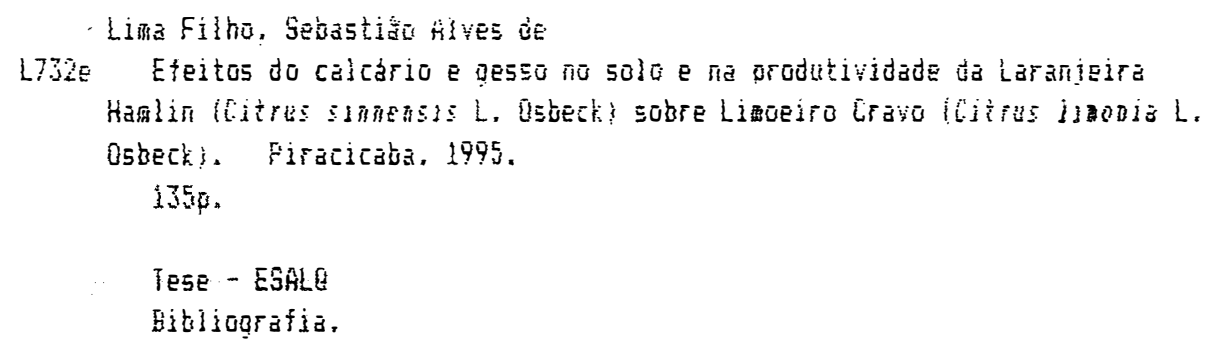

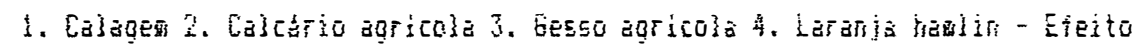

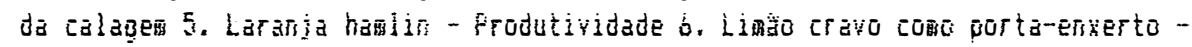
Eteito da calagen 7. Solo - Acidez I. Escola Sugerior de Horicultura Luiz de Quesioz, fistacicatia 
EFEITOS DO CALCÁRIO E GESSO NO SOLO E NA PRODUTIVIDADE DA LARANJEIRA HAMLIN (Citrus sinnensis L. Osbeck) SOBRE LIMOEIRO CRAVO (Citrus limonia L. Osbeck)

\author{
SEBASTIÃO ALVES DE LIMA FILHO
}

Aprovado em: 27/06/95

Comissão Julgadora:

Prof. Dr. Godofredo Cesar Vitti ESALQ/USP

Prof. Dr. Rafael Roberto Aloisi ESALQ/USP

Prof. Dr. Jairo Antonio Mazza ESALQ/USP

Prof. Dr. José Carlos Casagrande CCA/UFSCar

Prof. Dr. Joaquim Teófilo Sobrinho 
A "DEUS" que me permitiu,

Aos "PAIS" que me conceberam,

Aos "MESTRES" que me iluminaram,

Aos "AMIGOS" que me compreenderam e incentivaram

\section{Ofereço}

A minha esposa NILZA

e filhas GISELLE CHRISTIANE e MELISSA ISABELLE, razão específica da minha existência,

Dedico 


\section{AGRADECIMENTOS}

$\mathrm{O}$ autor agradece e registra o apoio financeiro e logístico de pessoas e entidades que em nenhum instante deixaram de incentivar a concretização deste trabalho de pesquisa.

Ao Prof. Dr. Godofredo César Vitti, pela sua competência, amizade e segura orientação deste trabalho;

Ao Prof. Dr. Geraldo Victorino de França, coordenador do Curso de Pós-Graduação em Solos e Nutrição de Plantas, pelo apoio e amizade dedicados;

À ESALQ/USP/Piracicaba-SP, através do Departamento de Ciências do Solo, pela infraestrutura de aprendizagem oferecida;

À Universidade Federal de São Carlos (UFSCar), através de seu campus de Ciências Agrárias em Araras-SP, pela oportunidade de aperfeiçoamento científico e tecnológico oferecida a seus docentes;

Ao Conselho Nacional de Desenvolvimento Científico e Tecnológico (CNPq) pela bolsa concedida, que na sua essência complementa o nobre trabalho de formação profissional das Instituições de Ensino e Pesquisa do país;

À Fazenda Colorado na pessoa de seu proprietário Bel. Lair Antonio de Sousa e seus técnicos: Eng $^{\mathrm{o}} \mathrm{Agr}^{\mathrm{o}}$ Leonardo Davinci Delben, Méd; 
Vet. Antonio Carlos de Sordi Sobreira e o Adm. Sr. Luiz Paulon, pelo apoio financeiro e técnico durante a condução deste trabalho;

À Sociedade Extrativa Dolomia Ltda, nas pessoas do Sr. Sérgio Satumino e do Eng ${ }^{\mathrm{o}}$ Agr $^{\mathrm{O}}$. Sérgio Luis Peretta, pelo apoio financeiro durante o desenvolvimento deste trabalho;

Ao Prof. Dr. José Carlos Rolim, Prof. Dr. Rubismar Stolf e Prof.

Dr. José Carlos Casagrande, docentes do CCA/UFSCar/Araras-SP, pelas sugestões;

Ao Sr. Fábio Sileno Tagliaferro, discente do Curso de Agronomia da ESALQ e estagiário do projeto, pelas colaborações prestadas;

Ao Sr. Luís Carlos de Sá, funcionário do CCA/UFSCar/Araras-SP, pelos serviços de computação dedicados;

À Comissão julgadora, pelas correções e sugestões apresentadas;

As pessoas amigas, que direta ou indiretamente, colaboraram durante o desenvolvimento deste trabalho. 


\section{SUMÁRIO}

Página

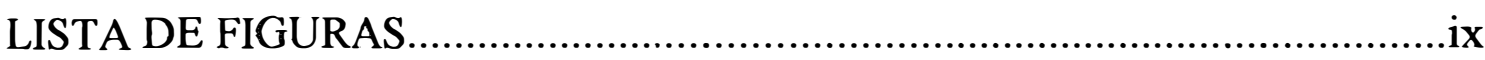

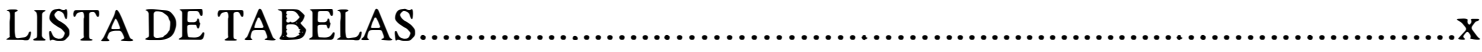

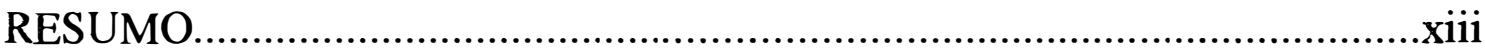

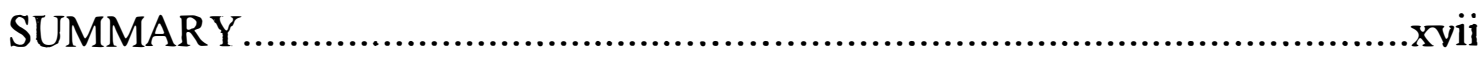

1. INTRODUÇÃO

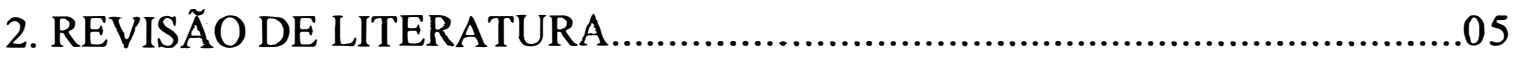

2.1. Respostas das culturas e do solo à aplicação da calagem em solos

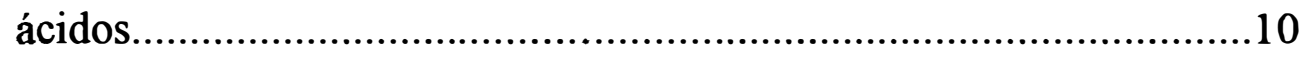

2.2. Respostas das culturas e do solo à aplicação de gesso em solos ácidos.

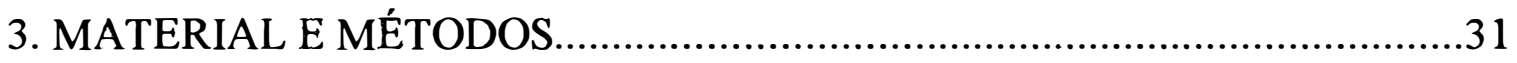

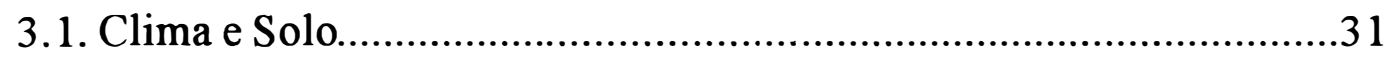

3.2. Delineamento experimental, tratamentos e detalhamento das

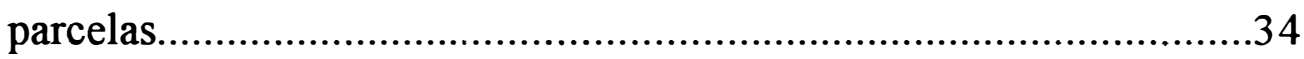

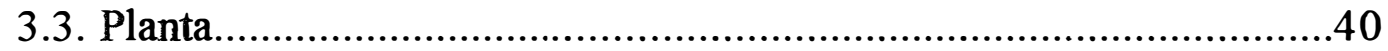

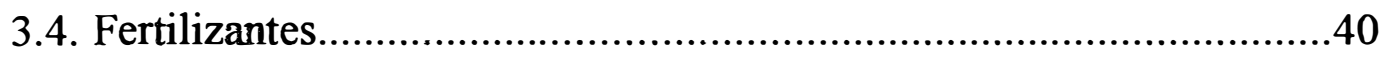

3.5. Instalação do experimento.............................................................. 41

3.5.1. Amostragem inicial de solo e folha.....................................41

3.5.2. Critérios adotados para a instalação do experimento.............42

3.5.3. Controle fitossanitário e de ervas daninhas..........................42

3.6. Critérios utilizados para amostragem de solo...................................43

3.7. Critérios utilizados para amostragem de folha.................................43

3.8. Critérios utilizados para amostragem de frutos.................................44 
3.9. Critérios utilizados na colheita das laranjas......................................44

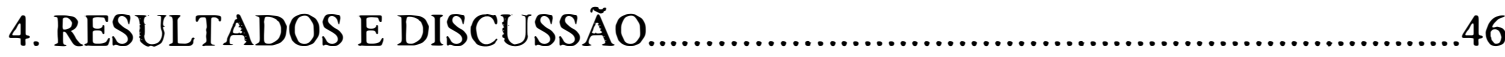

4.1. Efeitos dos tratamentos nas propriedades químicas do solo................46

4.1.1. $\mathrm{pH}, \mathrm{Al}^{3+}$ trocável, $\mathrm{H}^{+}+\mathrm{Al}^{3+}$ e porcentagem de satura-

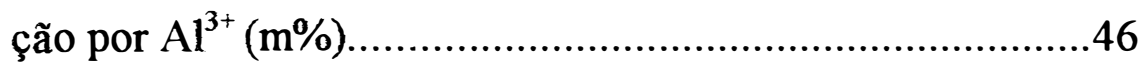

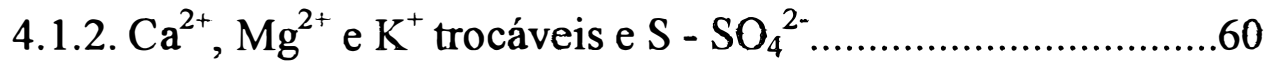

4.1.3. V\%, SB, CTC, M.O. e P..................................................79

4.2. Efeitos dos tratamentos na planta....................................................97

4.2.1. Macro e micronutrientes..................................................97

4.2.2. Dimensões físicas dos frutos..............................................107

4.2.3. Qualidades tecnológicas dos frutos...................................111

4.2.4. Produtividade da cultura..................................................114

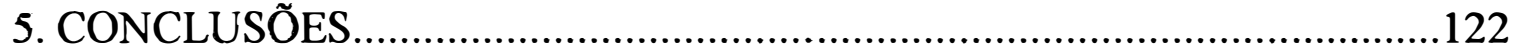

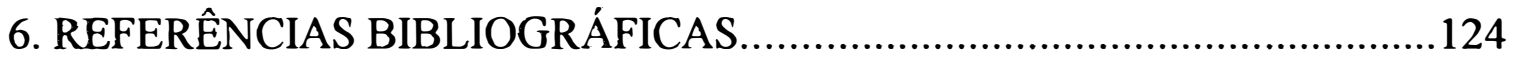




\section{LISTA DE FIGURAS}

1. Teores de $\mathrm{Al}^{3+}\left(\mathrm{mmol}_{\mathrm{c}} \cdot \mathrm{dm}^{-3}\right)$ em 3 profundidades de solo na $\mathbf{1}^{\mathrm{a} .}$ e $2^{\mathrm{a} .}$ épocas de amostragem.

2. Teores de $\mathrm{Ca}^{2+}\left(\mathrm{mmol}_{\mathrm{c}} \cdot \mathrm{dm}^{-3}\right)$ em 3 profundidades de solo na $1^{\mathrm{a} .}$ e $2^{\mathrm{a} .}$ épocas de amostragem.

3. Teores de $\mathrm{Mg}^{2+}\left(\mathrm{mmol}_{\mathrm{c}} \cdot \mathrm{dm}^{-3}\right)$ em 3 profundidades de solo na $1^{\mathrm{a} .}$ e $2^{\mathrm{a} .}$ épocas de amostragem.

4. Teores de $\mathrm{K}^{+}\left(\mathrm{mmol}_{\mathrm{c}} \cdot \mathrm{dm}^{-3}\right)$ em 3 profundidades de solo na $1^{\mathrm{a}}$ e $2^{\mathrm{a}}$. épocas de amostragem.

5. Teores de $\mathrm{SO}_{4}{ }^{2-}\left(\mathrm{mg} \cdot \mathrm{dm}^{-3}\right)$ em 3 profundidades de solo na $1^{\mathrm{a}}$ e $2^{\mathrm{a} .}$ épocas de amostragem.

6. Porcentagem de saturação por bases (V\%) em 3 profundidades de solo na

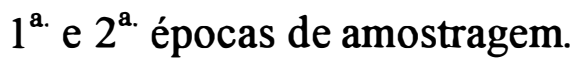

7. Teores de P em $\left(\mathrm{mg} . \mathrm{dm}^{-3}\right)$ em 3 profundidades de solo na $1^{\mathrm{a}}$ e $2^{\mathrm{a} .}$ épocas de amostragem.

8. Produtividades de laranja Hamlin em $t / h a$, obtidas na $1^{\text {a }}$ e $2^{\text {a. }}$ épocas de colheita (safras 1992/93 e 1993/94) 


\section{LISTA DE TABELAS}

Página

1. Dados de precipitações pluviométricas $(\mathrm{mm})$ registrados pela Fazenda Colorado (Araras-SP) período: 1992 a 1994

2. Resultados analíticos das amostras de solos coletadas em 3 profundidades, antes da instalação do experimento. .33

3. Quadro da análise de variância.. .34

4. Tratamentos e suas caracterizações. 36

5. Resultados analíticos dos corretivos e do gesso fornecidos pela Firma "Sociedade Extrativa Dolomia Ltda".

6. Valores de $\mathrm{pH}$ em 3 profundidades de solo ( $1^{\mathrm{a} a}$ época de amostragem safra 1992/93).

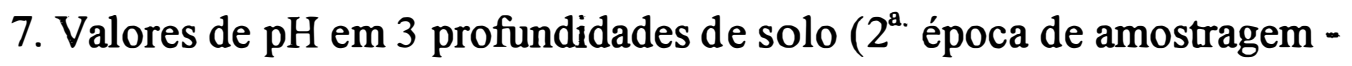
safra 1993/94). .48

8. Teores de $\mathrm{Al}^{3+}\left(\mathrm{mmol}_{\mathrm{c}} \cdot \mathrm{dm}^{-3}\right)$ em 3 profundidades de solo ( $1^{\mathrm{a} .}$ época de amostragem - safra 1992/93).

9. Teores de $\mathrm{Al}^{3+}\left(\mathrm{mmol}_{\mathrm{c}} \cdot \mathrm{dm}^{-3}\right)$ em 3 profundidades de solo ( $2^{\mathrm{a} .}$ época de amostragem - safra 1993/94).

10. Porcentagem de saturação por alumínio ( $\mathrm{m} \%)$ em 3 profundidades de solo ( $1^{\text {a. }}$ época de amostragem - safra 1992/93).

11. Porcentagem de saturação por alumínio ( $\mathrm{m} \%)$ em 3 profundidades de solo ( $2^{\text {a }}$ época de amostragem - 1993/94).

12. Teores de $\mathrm{H}^{+}+\mathrm{Al}^{3+}\left(\right.$ mmol $\left._{\mathrm{c}} \cdot \mathrm{dm}^{-3}\right)$ em 3 profundidades de solo $\left(1^{\mathrm{a}}\right.$ época de amostragem - safra 1992/93).

13. Teores de $\mathrm{H}^{+}+\mathrm{Al}^{3+}\left(\mathrm{mmol}_{\mathrm{c}} \cdot \mathrm{dm}^{-3}\right)$ em 3 profundidades de solo $\left(2^{\mathrm{a}}\right.$ época de amostragem - safra 1993/94). 
14. Teores de $\mathrm{Ca}^{2+}\left(\mathrm{mmol}_{\mathrm{c}} \cdot \mathrm{dm}^{-3}\right)$ em 3 profundidades de solo ( $1^{\mathrm{a}}$ época de amostragem - safra 1992/93).

15. Tores de $\mathrm{Ca}^{2+}\left(\mathrm{mmol}_{\mathrm{c}} \cdot \mathrm{dm}^{-3}\right)$ em 3 profundidades de solo (2 $2^{\mathrm{a}}$ época de amostragem - safra 1993/94).

16. Teores de $\mathrm{Mg}^{2+}\left(\mathrm{mmol}_{\mathrm{c}} \cdot \mathrm{dm}^{-3}\right)$ em 3 profundidades de solo ( $1^{\mathrm{a} .}$ época de amostragem - safra 1992/93)

17. Teores de $\mathrm{Mg}^{2+}\left(\mathrm{mmol}_{\mathrm{c}} \cdot \mathrm{dm}^{-3}\right)$ em 3 profundidades de solo ( $2^{\mathrm{a} .}$ época de amostragem - safra 1993/94).

18. Teores de $\mathrm{K}^{+}\left(\mathrm{mmol}_{\mathrm{c}} \cdot \mathrm{dm}^{-3}\right)$ em 3 profundidades de solo ( $1^{\mathrm{a}}$. época de amostragem - safra 1992/93).

19. Teores de $\mathrm{K}^{+}\left(\mathrm{mmol}_{\mathrm{c}} \cdot \mathrm{dm}^{-3}\right)$ em 3 profundidades de solo ( $2^{\mathrm{a}}$. época de amostragem - safra 1993/94).

20. Teores de $\mathrm{S}-\mathrm{SO}_{4}{ }^{2-}\left(\mathrm{mg} . \mathrm{dm}^{-3}\right)$ em 3 profundidades de solo ( $1^{\mathrm{a} a}$ época de amostragem - safra 1992/93).

21. Teores de $\mathrm{S}-\mathrm{SO}_{4}{ }^{2-}\left(\mathrm{mg} \cdot \mathrm{dm}^{-3}\right)$ em 3 profundidades de solo ( $2^{\mathrm{a} .}$ época de amostragem - safra 1993/94).

22. Porcentagens de saturação por bases (V\%) em 3 profundidades de solo ( $1^{\text {a }}$ época de amostragem - safra 1992/93) .80

23. . Porcentagens de saturação por bases (V\%) em 3 profundidades de solo (2a época de amostragem - safra 1993/94).

24. Soma de bases trocáveis - SB $\left(\mathrm{mmol}_{\mathrm{c}} \cdot \mathrm{dm}^{-3}\right)$ em 3 profundidades de solo ( $1^{\text {a }}$ época de amostragem - safra 1992/93)

25. Soma de bases trocáveis - SB $\left(\mathrm{mmol}_{\mathrm{c}} \cdot \mathrm{dm}^{-3}\right)$ em 3 profundidades de solo (2a época de amostragem - safra 1993/94).

26. Capacidade de troca de cátions-CTC $\left(\mathrm{mmol}_{\mathrm{c}} \cdot \mathrm{dm}^{-3}\right)$ em 3 profundidades de solo ( $1^{\text {a }}$ época de amostragem - safra 1992/93). .89

27. Capacidade de troca de cátions-CTC $\left(\mathrm{mmol}_{\mathrm{c}} \cdot \mathrm{dm}^{-3}\right)$ em 3 profundidades de solo ( $2^{\mathrm{a}}$ época de amostragem - safra 1993/94). .90 
28. Teores de matéria orgânica-M.O. $\left(\mathrm{g}^{\mathrm{dm}} \mathrm{dm}^{-3}\right)$ em 3 profundidades de solo ( $1^{\text {a. }}$ época de amostragem - safra 1992/93).

29. Teores de matéria orgânica-M.O. $\left(\mathrm{g} \mathrm{dm}^{-3}\right)$ em 3 profundidades de solo ( $2^{\text {a }}$ época de amostragem - safra 1993/94).

30. Teores de $\mathrm{P}$ em $\left(\mathrm{mg} \cdot \mathrm{dm}^{-3}\right)$ em 3 profundidades de solo ( $1^{\mathrm{a}}$ época de amostragem - safra 1992/93).

31. Teores de $\mathrm{P}$ em $\left(\mathrm{mg} \cdot \mathrm{dm}^{-3}\right)$ em 3 profundidades de solo ( $2^{\mathrm{a}}$ época de amostragem - safra 1993/94).

32. Teores de macronutrientes $\left(\mathrm{g} \cdot \mathrm{Kg}^{-1}\right)$ em folhas da laranjeira Hamlin $\left(1^{\mathrm{a}}\right.$ época de colheita - safra 1992/93).

33. Teores de macronutrientes $\left(\mathrm{g} \cdot \mathrm{Kg}^{-1}\right)$ em folhas da laranjeira Hamlin $\left(2^{\mathrm{a}}\right.$ época de colheita - safra 1993/94).

34. Teores de micronutrientes $\left(\mathrm{mg} \cdot \mathrm{Kg}^{-1}\right)$ em folhas da laranjeira Hamlin $\left(1^{\mathrm{a}}\right.$. época de colheita - safra 1992/93).

35. Teores de micronutrientes $\left(\mathrm{mg} \cdot \mathrm{Kg}^{-1}\right)$ em folhas da laranjeira Hamlin $\left(2^{\mathrm{a}}\right.$ época de colheita - safra 1993/94).

36. Dimensões fisicas determinadas nas laranjas ( $1^{\mathrm{a}}$ época de colheita safra 1992/93)

37. Dimensões físicas determinadas nas laranjas (2 $2^{\mathrm{a}}$ época de colheita safra 1993/94)

38. Resultados das análises qualitativas do suco das laranjas ( $1^{\mathrm{a}}$ época de colheita - safra 1992/93).

39. Resultados das análises qualitativas do suco das laranjas ( $2^{\mathrm{a}}$ época de colheita - safra 1993/94)

40. Produtividades de laranja em caixas/planta e em tha ( $1^{\text {a }}$ época de colheita - safra 1992/93).

41. Produtividades de laranja em caixas/planta e em t/ha ( $2^{\mathrm{a}}$ época de colheita - safra 1993/94). 


\title{
EFEITOS DO CALCÁRIO E GESSO NO SOLO E NA PRODUTIVIDADE DA LARANJEIRA HAMLIN (Citrus sinnensis L. Osbeck) SOBRE LIMOEIRO CRAVO (Citrus limonia L. Osbeck)
}

\author{
Autor: SEBASTIÃO ALVES DE LIMA FILHO \\ Orientador: PROF. DR. GODOFREDO CESAR VITTI
}

Resumo

O objetivo deste trabalho foi avaliar os efeitos de tipos de calcários aplicados isoladamente e de misturas de calcários e de gesso nas características químicas de um Latossolo Vermelho Escuro, textura argilosa, em 3 profundidades, a saber: $0-20 \mathrm{~cm}, 20-40 \mathrm{~cm}$ e $40-60 \mathrm{~cm}$ e na planta através das análises dos teores de macro e micronutrientes nas folhas, das determinações das dimensões físicas dos frutos, das análises qualitativas do suco e da produtividade de laranja Hamlin, em 2 safras: 1992/93 e 1993/94.

O experimento foi instalado na Fazenda Colorado, em Araras, Estado de São Paulo, na latitude $22^{\circ}$ e $18^{\prime}$ Sul, longitude $47^{\circ}$ e $23^{\prime} \mathrm{W}$, altitude média de $617 \mathrm{~m}$ e o clima foi classificado como CWa, mesotérmico de inverno seco. 
Utilizou-se o delineamento estatístico de blocos casualizados com 7 tratamentos e 6 repetições, portanto 42 parcelas. A parcela experimental foi formada por 10 plantas em linha, alternadas por outras 10 plantas que foram utilizadas como proteção ou bordadura da unidade experimental e, foram consideradas como "plantas úteis" as 8 laranjeiras centrais de cada parcela. A idade do pomar é de 13 anos e as laranjeiras foram plantadas segundo o espaçamento de $7 \mathrm{~m}$ entre plantas e $8 \mathrm{~m}$ nas entrelinhas, portanto 178 plantas/ha.

Anualmente, foram feitas adubações básicas (NPK + micronutrientes) e aplicações de produtos químicos através de pulverizações foliares para fornecer micronutrientes e manter o controle fitossanitário preventivo e curativo da cultura.

Os produtos usados nos tratamentos foram: calcário dolomítico, calcítico e magnesiano, aplicados isoladamente e, misturas de calcário dolomítico com calcário calcítico nas proporções de $(50 \%+50 \%)$ e $(2 / 3+1 / 3)$ respectivamente, e calcário dolomítico com gesso $(75 \%+25 \%)$.

As doses dos calcários foram calculadas, a fim de se elevar a saturação por bases (V\%) do solo a $70 \%$ na profundidade de $0-20 \mathrm{~cm}$. A dose de gesso foi calculada com a finalidade de se elevar o teor de $\mathrm{Ca}^{2+}$ no solo a 20 $\mathrm{mmol}_{\mathrm{c}} \cdot \mathrm{dm}^{-3}$, na profundidade de $0-40 \mathrm{~cm}$.

O calcário e o gesso foram aplicados manualmente logo após a colheita da laranja na safra 1991/92. Após a aplicação dos produtos, fez-se uma 
dupla operação de subsolagem nas entrelinhas, na profundidade aproximada de 60 cm. Em seguida, realizou-se uma operação de gradagem cruzada (na linha e na entrelinha da laranjeira) a fim de incorporar o calcário e o gesso da melhor maneira possível.

O solo foi amostrado para fins de avaliação das características químicas do solo em 3 profundidades, a saber: $0-20 \mathrm{~cm}, 20-40 \mathrm{~cm}$ e $40-60 \mathrm{~cm}$, na projeção da copa da laranjeira, durante o mes de março de cada ano, aos 12 e 24 meses após a aplicação dos tratamentos, respectivamente às safras: 1992/93 (1 ${ }^{\mathrm{a}}$. época de amostragem) e 1993/94 ( $2^{\mathrm{a} .}$ época de amostragem).

Coletou-se amostras de folhas durante o mes de fevereiro de cada ano, na mesma periodicidade das amostras de solo. Amostrou-se 4 folhas/planta na altura mediana da copa ( 1 folha em cada quadrante) nas 8 "plantas úteis" de cada parcela para serem determinados os teores de macro e micronutrientes.

As laranjas foram colhidas durante os meses de junho e de julho de cada ano nas safras: $1992 / 93$ e 1993/94, tendo-se determinado as suas produtividades em caixas/planta e t/ha. Nesta ocasião, amostrou-se 8 frutos/parcela a fim de serem realizadas as medidas das dimensões fisicas e as análises tecnológicas do fruto.

Os resultados obtidos permitiram concluir que houve resposta acentuada na produtividade da laranja Hamlin à aplicação da mistura de calcário dolomítico e gesso $(75 \%+25 \%)$, nas doses de $2,95 \mathrm{t} / \mathrm{ha}$ e $1 \mathrm{t} / \mathrm{ha}$, respectivamente, 
na safra 1993/94. Os demais tratamentos não apresentaram a mesma eficácia com relação a produtividade da cultura. Os corretivos e o gesso não influenciaram significativamente os seguintes parâmetros analisados: teores de macro e micronutrientes nas folhas; dimensões fisicas dos frutos e a qualidade tecnológica da laranja. Houve lixiviação de $\mathrm{S}^{-\mathrm{SO}_{4}}{ }^{2-}$ em subsuperficie $(20-60 \mathrm{~cm})$ aos 24 meses após a aplicação da mistura de calcário dolomítico + gesso nas doses de 2,96 t/ha e $1 \mathrm{t} / \mathrm{ha}$, respectivamente. 


\title{
EFFECTS OF LIME AND PHOSPHOGYPSUM ON THE SOIL AND ON THE PRODUCTIVITY OF HAMLIN ORANGE (Citrus sinnensis L.Osbeck) GRAFTED ON "CRAVO" LEMON (Citrus limonia L. Osbeck).
}

\author{
Author: SEBASTIÃO ALVES DE LIMA FILHO \\ Adviser: PROF. DR. GODOFREDO CESAR VITTI
}

Summary

This research was carried out with the objective of evaluating the effects of different kinds of lime when applied alone and in mixtures of limes and phosphogypsum on the chemical characteristics of a dark-red latosol, clayey texture, at 3 depths: $0-20 \mathrm{~cm}, 20-40 \mathrm{~cm}$ and $40-60 \mathrm{~cm}$ as well as on the plant. Evaluations in plants were done by analysing the leaves macro and micronutrients, determining the fruit physical dimensions, qualitatively analysing the juice and determining the productivity of the Hamlin orange in two harvesting seasons: $1992 / 93$ and 1993/94.

The experiment was installed at the Colorado Farm, in Araras, State of São Paulo, latitude $22^{\circ}$ and $18^{\prime}$ South, longitude $47^{\circ}$ and $23^{\prime} \mathrm{W}$, average altitude $617 \mathrm{~m}$. Climate has been classified as $\mathrm{CWa}$, mesothermic with dry winter.

The experimental design was randomized blocks with 7 treatments and 6 replications each, summing up 42 plots. Each experimental plot was composed by 10 plants in the same row, alternated by 10 other plants which served as a protection or border for the experimental plot. The effective plot was constituted 
by 8 citrus plants in the center of each plot. The orchard was 13 -years old and the trees were planted with 7-meter spacing between plants and 8 meters in the interrows.

Basic fertilizing (NPK + micronutrients) and application of chemical products by foliar spraying were done in a year basis. This practice was performed for providing micronutrients and to maintain plant sanity both preventively and curatively.

Products used as treatments were: dolomitic, calcitic, and magnesic limes, applied alone as well as dolomitic and calcitic mixtures at the proportions $50 \%+$ $50 \%$, and $2 / 3+1 / 3$, and dolomitic lime plus phosphogypsum at the proportion $75 \%+25 \%$.

Lime doses were calculated as to raise soil bases saturation (V\%) to $70 \%$ at the depth of $0-20 \mathrm{~cm}$. Phosphogypsum doses was calculated as to raise soil $\mathrm{Ca}^{2+}$ content to $20 \mathrm{mmol}_{\mathrm{c}} \cdot \mathrm{dm}^{-3}$, at the depth of $0-40 \mathrm{~cm}$.

Lime and phosphogypsum were applied manually just after orange harvesting at the 1991/92 season. A double subsoiling operation in the interrows at approximately $60 \mathrm{~cm}$ depth, was done soon after products application. A crossed harrowing (in the row and interrow) was then done in order to better incorporate lime and phosphogypsum.

Soil was sampled for evaluating of soil chemical characteristics at 3 depths: $0-20 \mathrm{~cm}, 20-40 \mathrm{~cm}$, and $40-60 \mathrm{~cm}$, at the area shaded by the tree, yearly in March, 12 and 24 months after treatments application. This sampling corresponded to the 1992/93 harvesting (1st. sampling time), and 1993/94 harvesting seasons (2nd. sampling time). 
Leaf samples were collected during the month of February each year, with the same periodicity of the soil samplings. In order to determine macro and micronutrient contents, 4 leaves/plant at an average height of the tree crown were collected (1 leaf in each quarter) from 8 plants in the effective plot.

Orange harvesting was done in June and July each year at both 1992/93 and 1993/94 harvesting seasons. Productivity was determined based on number of boxes/plant and t/ha. Eight fruits/plot were then collected for determining physical dimensions and also to carry technological analysis.

Results allowed to conclude that a pronounced response to application of the mixture of dolomitic lime and phosphogypsum $(75 \%+25 \%)$, at the doses of 2:95 t/ha and $1 \mathrm{t} / \mathrm{ha}$, respectively, occurred conceming Hamlin orange productivity at the 1993/94 harvesting season. The other treatments were not as effective concerning crop productivity. Limes and phosphogypsum did not significantly influence the following parameters: leaf macro and micronutrient contents; fruit physical dimensions and technological quality. Subsurface lixiviating of $\mathrm{S}^{-\mathrm{SO}_{4}}{ }^{2-}$ occurred at a depht of $20-60 \mathrm{~cm}, 24$ months after application of dolomitic lime + phosphogypsum mixture at the 2.95 t/ha and 1 tha, respectively. 


\section{INTRODUÇÃO}

A citricultura brasileira somente recebeu os primeiros incentivos econômicos na década de 1920, marcada pelo início da comercialização de frutos “in natura" nos mercados internos e externos, principalmente neste último.

A comercialização das plantas cítricas expandiu até 1963 quando atingiu uma produção anual da ordem de 14 milhões de caixas, já contando naquela época, com um excedente de frutos frescos em torno de $10 \%$.

Em virtude deste "superávit" e da ocorrência de geadas na Flórida em 1963, deu-se o início do processamento industrial de suco concentrado congelado a partir de 1964 que seria a solução transparente para os problemas dos excedentes de produção e consequentemente, se estabeleceria uma política de preços mais estáveis, mais justa e incentivadora. Desta forma, haveria o crescimento das áreas cultivadas com citros, oferecendo maiores quantidades de sucos para os mercados internacionais.

$\mathrm{O}$ setor privado respondeu prontamente aqueles incentivos e em 1970, as indústrias nacionais já esmagavam cerca de $34 \%$ da produção nacional (FAO, 1990). Passou a $80 \%$ em 1988 , na safra de 1992 , tendo processado $76 \%$ 
(275 milhões de caixas) e na safra de 1993, 71,5\% (256 milhões de caixas). Nesse período, houve um aumento de consumo de frutas "in natura" por parte do mercado interno.

Atualmente, a citricultura paulista é a maior do mundo e com este mérito, também estão alguns desafios, dentre eles, os técnico-agronômicos que sem dúvida têm que ser resolvidos em caráter de prioridade pois influenciam diretamente a produtividade dos citros.

A maioria dos solos brasileiros apresenta condições de acidez, caracterizando-se por possuírem baixos teores de cálcio e magnésio e, em determinados casos, alta saturação por $\mathrm{Al}^{3+}$ (m\%) e teores elevados de manganês, menor disponibilidade de macronutrientes, maior fixação de fósforo principalmente nos solos argilosos, maior mineralização da matéria orgânica, menor fixação de $\mathrm{N}_{2}$ e maior disponibilidade dos micronutrientes, exceto o cloro e o molibdênio (MALAVOLTA \& VIOLANTE NETTO, 1989).

Era de se esperar que na maior parte das áreas de expansão da citricultura no Estado de São Paulo acontecessem sobre solos com problemas de acidez. Aliado a esse fato, estão as elevadas e constantes adubações minerais, principalmente as nitrogenadas que normalmente são aplicadas localizadamente na projeção da copa das laranjeiras, contribuindo decididamente para agravar ainda mais este problema. 
Em solos ácidos, as raízes das plantas não se desenvolvem adequadamente, ou seja, não exploram um volume de solo suficiente para atender às suas necessidades nutricionais $\mathrm{e}$ com isto, fatalmente, apresentarão decréscimos de produtividade.

Este problema pode ser resolvido ou minimizado dependendo do nível de solução que adotarmos. A prática que tem sido mais utilizada pela sua eficiência e economicidade tem sido a da calagem.

$$
\text { Pesquisadores como RAIJ (1991) e MALAVOLTA (1991) }
$$

acreditam que o aspecto mais importante da calagem para as culturas seja a longa duração do efeito residual do calcário no solo, favorecendo a nutrição das plantas.

Atualmente, tem sido desenvolvidos alguns trabalhos com fosfogesso ou gesso agrícola, no sentido de aumentar o teor de cálcio em profundidade e reduzir a acidez do subsolo. Um dos grandes efeitos positivos da aplicação do gesso em solos ácidos é promover um maior desenvolvimento do sistema radicular da planta em profundidade permitindo que ela absorva maiores quantidades de água e nutrientes (PAVAN \& VOLKWEISS, 1986).

Recentemente, trabalhos de pesquisa têm demonstrado que a aplicação de calcário e de gesso agrícola não devem ser entendidos como práticas isoladas e independentes mas como tecnologias interdependentes, que se complementam. 
Este trabalho teve como objetivo avaliar os efeitos de tipos de calcários aplicados isoladamente e de misturas de calcários e de misturas de calcário e gesso nas características químicas de um Latossolo Vermelho Escuro, textura argilosa, em 3 profundidades e, na planta, através das determinações dos teores de macro e micronutrientes nas folhas, dimensionamento físico dos frutos, caracterização qualitativa do suco da laranja e a avaliação da produtividade da cultura em 2 safras agrícolas (1992/93 e 1993/94), até o momento. Esta pesquisa integra-se ao Projeto: Calcário e Gesso ( Convênio: Dolomia/Solorrico/ ESALQ/FEALQ) com mais 2 unidades experimentais instaladas em áreas comerciais no município de Conchal-SP. Estes experimentos deverão ter continuidade nos anos subsequentes a fim de se obter novas informações, principalmente, sobre os efeitos residuais do calcário e gesso aplicados no solo e suas possíveis influências sobre a planta. 


\section{REVISÃO DE LITERATURA}

Os citros, como todas as culturas, exigem macro e micronutrientes para a sua nutrição mineral os quais são fornecidos às plantas através da utilização de adubos e corretivos de solo. A preocupação básica dos produtores de laranja tem sido fornecer às plantas, quantidades suficientes economicamente de nitrogênio, fósforo, potássio, cálcio, magnésio, boro, manganês e zinco através dos processos de adubações e calagens convencionais, não se preocupando, na maioria das vezes, de se levar em consideração os tipos de fertilizantes e corretivos disponíveis no mercado, bem como suas dosagens a serem aplicadas em função dos resultados das análises de solo e de planta e das reações que estes produtos sofrem no solo, afetando a disponibilidade dos nutrientes para as plantas.

No caso específico da aplicação de corretivos em citros, a preocupação é mais acentuada, pois esta planta apresenta uma característica diferenciada em relação a maioria das culturas ou seja, apresenta alta exigência em cálcio dentre outros nutrientes, para formar os seus tecidos (CHAPMAN, 1968). É de se esperar que o seu maior desenvolvimento ocorra em 
solos com $\mathrm{pH}$ elevado, onde haverá maior disponibilidade de cálcio. Na literatura existem autores como CHANDLER (1958) e COHEN (1983) que acreditam que os citros desenvolvem muito bem numa ampla faixa de $\mathrm{pH}$ entre 4 e 9. Existem outros como GUEST \& CHAPMAN (1944) que obtiveram melhores produtividades dos citros, decorrentes de maiores disponibilidades de nutrientes, quando desenvolveram experimento em solo arenoso com baixo poder tampão e pH entre 5,5 e 6,0.

Parece existir um consenso entre pesquisadores de que os citros desenvolvem-se bem e produzem mais quando o solo apresenta $\mathrm{pH}$ em água na faixa de 5,8 a 6,0, correspondente a uma saturação por bases (V\%) entre 60 e 70\% (VITTI, 1989; RAIJ, 1991). Tanto o desenvolvimento radicular como o de plantas crescidas em solos com elevada acidez, são negativamente afetados por níveis baixos de cálcio no solo e ou por níveis elevados de alumínio (FURLANI \& BERTON, 1992). Estas situações ocorrem com frequência na maioria dos solos brasileiros, principalmente naqueles que possuem elevada acidez nas camadas subsuperficiais (DEMATTÊ, 1981). É o caso da grande maioria dos solos sob vegetação de cerrado que apresenta acidez elevada e as plantas têm seu crescimento afetado devido a toxidez de Al e/ou Mn (LOPES, 1982).

Na prática, a maneira mais econômica de se diminuir a acidez dos solos e fornecer nutrientes como o cálcio e magnésio, principalmente, é através do uso de corretivos agrícolas. Estes, não somente fornecem macro e micronutrientes 
às plantas como também alteram várias características fisicas, químicas e biológicas do solo, de tal modo, que geralmente é muito dificil de se explicar quais são os fatores responsáveis pelos acréscimos de produção obtidas com a adoção da calagem (QUAGGIO,1986).

RAIJ (1991) definiu a calagem como sendo uma prática complexa em seus efeitos a qual promove a diminuição da acidez dos solos com insolubilização de elementos tóxicos, principalmente alumínio e manganês; aumenta os teores de cálcio e magnésio no solo; aumenta a disponibilidade de fósforo e molibdênio; diminui a disponibilidade de potássio e micronutrientes como o zinco, boro, manganês, cobre e ferro; promove efeitos favoráveis na microflora do solo, inclusive em bactérias fixadoras de nitrogênio; melhora as propriedades fisicas do solo, pela ação floculante do cálcio e, desenvolve o sistema radicular das plantas, ampliando a sua capacidade em obter água e nutrientes do solo. Além de todos estes efeitos, existem as diferenças acentuadas entre o comportamento varietal, na tolerância ao alumínio e manganês tóxicos, o que leva a um comportamento variável frente à calagem, dependendo do fator relacionado à acidez do solo que for o mais importante.

As recomendações de calagem para citros, geralmente baseiam-se na elevação do $\mathrm{pH}$ do solo para a faixa de 5,5 a 6,0 com o objetivo de garantir a correção da acidez do solo e o fornecimento de cálcio e magnésio, principalmente, e segundo SMITH (1966), se evitará os prejuízos causados às 
plantas devido ao excesso de cobre e de alumínio no solo, os quais promovem uma acentuada redução do número de raízes, tornando-as curtas e grossas, reduzindo drasticamente o volume de solo explorado pelas raízes das plantas cítricas repercutindo diretamente em redução de produtividade.

$\mathrm{Na}$ verdade, elevar o $\mathrm{pH}$ de um solo é o mesmo que aumentar a \% de saturação por bases (V\%), pois existe uma relação muito estreita entre estes 2 parâmetros (RAIJ,1981). Para os citros, de acordo com VIOLANTE NETTO et al. (1988) e o G.P.A.C.C. (1990), a faixa adequada de saturação por bases (V\%) encontra-se entre 60 e $70 \%$. Quando o valor encontrado na análise de solo (profundidade 0-20 cm) estiver dentro desta faixa, a calagem não é recomendada. Caso esteja abaixo de $60 \%$ faz-se o cálculo para atingir $70 \%$.

$\mathrm{Na}$ prática, observam-se duas situações importantes as quais merecem reflexão, antes de se buscar a melhor maneira de solucionar os problemas de acidez do solo e suas decorrentes desordens nutricionais.

A primeira situação a ser considerada é que, embora existam tecnologias disponíveis para se corrigir adequadamente a acidez do solo, com prioridade na implantação da cultura, os agricultores quase na sua totalidade não as adotam e, quando aplicam estas medidas corretivas, nem sempre são feitas adequadamente. Dessa maneira, a situação se agrava ao longo dos anos, geralmente ocorrendo decréscimos de produtividade, justamente numa fase dificil de se solucionar estes problemas, pois a cultura já se encontrará instalada. Nesta 
fase do ciclo da cultura fica muito dificil realizar incorporações profundas dos corretivos a fim de corrigir eficientemente a acidez subsuperficial do solo, sem contudo, prejudicar o sistema radicular das plantas.

A segunda situação a ser considerada é que a calagem embora seja uma prática antiga e portanto, exaustivamente pesquisada e recomendada, ainda é muito pouco utilizada na citricultura paulista. ROSSETTO et al. (1988), efetuaram amostragens de pomares com mais de 8 anos de idade entre produtores no Estado de São Paulo, considerando em seu trabalho, o período anterior a 1985 e entre 1985 e 1987 e, observaram que dentre os 1.321 pomares amostrados, $14,5 \%$ deles nunca receberam calagem; em $25,5 \%$, foram aplicados calagens antes de 1985 e, o mais grave, que 57,5\% dos pomares amostrados não tinham recebido calcário nos últimos 3 anos. Além disso, $68 \%$ desses pomares tiveram as suas produtividades iguais ou inferiores a 2 caixas/planta (produtividades antieconômicas).

MALAVOLTA \& VIOLANTE NETTO (1989), apresentaram dados sobre frequência de ocorrências das classes de fertilidade nos resultados de análise de solo, para amostras de laranjais em produção analisados pelo IAC durante 4 anos e evidenciaram os seguintes aspectos importantes: em mais de $50 \%$ das amostras analisadas o $\mathrm{pH}$ era baixo; a saturação por bases (V\%) era insuficiente e o teor de cálcio estava abaixo dos limites aceitáveis. 
Nesse sentido, duas observações parecem bastante importantes: a primeira é de alertar os produtores em adotar a prática da calagem e ou gessagem de maneira eficiente, no momento da implantação da cultura a fim de se beneficiar das vantagens que elas proporcionam durante um longo período, através dos seus efeitos residuais; a segunda, que atualmente é tão importante quanto a primeira, refere-se a necessidade de oferecer aos citricultores melhores alternativas tecnológicas para aplicação de corretivos e ou gesso, principalmente nos pomares em produção, a fim de se maximizar o fator produtividade, objetivo principal deste trabalho de pesquisa.

\subsection{Respostas das culturas e do solo à aplicação da calagem em solos ácidos}

A calagem no Brasil é uma prática agrícola muito antiga. Tem sido reconhecida pelos técnicos e produtores de um modo geral como sendo a maneira mais econômica de se diminuir a acidez dos solos. Esta acidez é a principal causa das baixas produtividades das culturas nos solos brasileiros.

VITTI (1989); MALAVOLTA \& VIOLANTE NETTO (1989);

RAIJ \& PEECH (1972); RAIJ (1991); QUAGGIO (1989), dentre outros pesquisadores, resumiram os principais efeitos da calagem:

- ação neutralizante do alumínio e manganês existentes nos solos ácidos; 
- relevante fornecimento de nutrientes às plantas, como o cálcio e magnésio, principalmente;

- aumento da disponibilidade de fósforo e molibdênio;

- favorece a nitrificação da matéria orgânica do solo;

- exerce efeito positivo na fixação simbiótica do nitrogênio;

- favorece as propriedades físicas dos solos pela adição de cátions floculantes aos colóides do solo: cálcio e magnésio;

- propicia no solo condições da planta desenvolver o seu sistema radicular, permitindo-lhe maior aproveitamento de nutrientes e água do solo;

- exerce no solo uma ação residual dos seus efeitos, de longa duração, propiciando às plantas maior desenvolvimento vegetativo e de produção.

Há muito tempo a importância da calagem vem sendo reconhecida e recomendada por diversos pesquisadores e segundo QUAGGIO (1983 e 1986), utilizando-se de várias metodologias quase sempre baseadas apenas no $\mathrm{pH}$ e no teor de matéria orgânica dos solos, embora já existissem metodologias mais modernas publicadas. A metodologia que se baseava no critério do alumínio trocável por COLEMAN et al. (1958) e KAMPRATH (1970), passou a ser a mais usada na maioria dos Estados Brasileiros, excetuando-se os Estados de Santa Catarina e Rio Grande do Sul que optaram pelo método SMP que preconizava elevar o pH a 6,0 para a maioria das culturas (QUAGGIO, 1986). No Estado de São Paulo, para os solos tropicais, adotava-se o critério de neutralização do 
alumínio, complementado pela elevação dos teores de cálcio mais magnésio a 2 meq $/ 100 \mathrm{~cm}^{3}$ (RAIJ, 1991). Calagens muito elevadas não seriam indicadas para solos tropicais.

Dezenas de ensaios sobre calagem foram realizados com a finalidade de comparar os critérios de recomendação desta prática.

Para RAIJ (1991), a calagem necessita neutralizar, para promover produções máximas, além do alumínio, parte da acidez devida ao hidrogênio não dissociado, de modo a elevar o valor $\mathrm{pH}$ em água pelo menos até 6,0 , ou a saturação por bases (V\%) a um mínimo de $60 \%$.

Desta forma, para os citros, a necessidade de calagem é calculada tomando-se por base a elevação do $\mathrm{pH}$ em água na faixa de 5,8 a 6,0 o que corresponde a uma saturação por bases (V\%) da ordem de 60 a 70\% (RAIJ, 1983; VITTI, 1984; VITTI, 1989).

Vários ensaios realizados, com diversas culturas, obtiveram resultados e levaram à mesma conclusão, dentre eles, MALAVOLTA (1976), trabalhando com citros, observou que o maior crescimento de mudas de laranjeira em solos de textura média ocorreu quando a saturação por bases (V\%) era igual a $70 \%\left(\mathrm{Ca}^{2+} \% \mathrm{CTC}=50 ; \mathrm{Mg}^{2+} \% \mathrm{CTC}=15\right.$ e $\left.\mathrm{K}^{+} \% \mathrm{CTC}=5\right)$, o pH em água $=$ 6,0 e $\% \mathrm{H}^{+}$e $\% \mathrm{Al}^{3+}$ na CTC efetiva do solo foram de 28 e $2 \%$, respectivamente.

Em geral, as respostas das culturas à calagem dependem basicamente de fatores ligados à planta (carga genética), ao solo (natureza do 
complexo coloidal) e ao tipo de corretivo (eficiência neutralizante), QUAGGIO (1986), porém todos estes fatores se ligam na mesma interface, "acidez dos solos". A acidez dos solos e a toxidez devido ao alumínio e manganês, são os principais fatores que limitam o crescimento de plantas em solos ácidos.

O alumínio limita o crescimento radicular, promove o engrossamento das raízes e inibe o crescimento das raízes laterais (FOY,1984). Como consequência da redução no desenvolvimento do sistema radicular, ocorrem diminuições significativas da absorção da água e nutrientes pelas plantas das camadas subsuperficiais do solo MENGEL \& KIRKBY ${ }^{1}$ e FOY ${ }^{2}$, citados por CARVALHO (1994).

Num primeiro instante, a aplicação genérica de corretivos agrícolas é a melhor alternativa para se reduzir os efeitos da acidez dos solos.

Não há dúvidas sobre a sua eficácia relativa mas, tem-se que tomar alguns cuidados, quanto a sua utilização, pois doses elevadas de calcários aplicados em solos com camadas subsuperficiais muito ácidas podem reduzir sensivelmente a acidez, como também podem provocar desequilíbrios no complexo sistema coloidal do solo e afetar direta e negativamente a produtividade das culturas (RAIJ et al., 1982).

\footnotetext{
${ }^{1}=$ MENGEL, K. \& KIRKBY, E.A. Principles of plant nutrition. 3 ed. Bern, International Potash Institute, 1982. $655 \mathrm{p}$.

${ }^{2}=$ FOY, C.D. Physiological effects of hidrogen, aluminum and manganese toxicities in acid soils. In: ADAMS, F., ed. Soil acidity and liming. 2 ed. Madison, ASA, 1984. p. 57-98.
} 
Trabalhando em solo de textura muito argilosa (Latossolo Vermelho Escuro), SOUSA \& RITCHEY (1986), aplicaram diversas doses de calcário dolomítico e observaram que a acidez do solo foi reduzida até $60 \mathrm{~cm}$ de profundidade mas, este efeito somente pode ser observado após 8 anos da aplicação do calcário e, nas doses superiores a 7,5 t/ha.

Em cana-de-açúcar, MEDINA \& BRINHOLI (1991), instalaram um ensaio em Terra Roxa estruturada distrófica $(\mathrm{pH}=5,3 ; \%$ M.O. $=2,9 ; \mathrm{meq} / 100 \mathrm{~g}$ TFSA de $\mathrm{H}^{+}+\mathrm{Al}^{3+}=3,1$; meq/100g TFSA de $\mathrm{K}^{+}=0,31$; meq $/ 100 \mathrm{~g}$ TFSA de $\mathrm{PO}_{4}{ }^{3-}=0,36 ; \mathrm{meq} / 100 \mathrm{~g}$ TFSA de $\mathrm{Ca}^{2+}=2,9 ; \mathrm{meq} / 100 \mathrm{~g}$ TFSA de $\mathrm{Mg}^{2+}=1,6 ; \mathrm{S}=$ 4,$8 ; \mathrm{CTC}=7,9$ e V\%=61,0) e aplicaram calcário dolomítico exclusivo $(1,2 \mathrm{t} / \mathrm{ha})$; gesso exclusivo (1,2 e $2,4 \mathrm{t} / \mathrm{ha})$ e misturas de calcário + gesso $(0,8+0,4 \mathrm{t} / \mathrm{ha})$; $(0,6+0,6$ tha $)$ e $(0,4+0,8 \mathrm{t} / \mathrm{ha})$, respectivamente, em cana-planta, variedade IAC 58-480. Concluíram que não havia necessidade de se fazer calagem, gessagem ou ainda calagem e gessagem nas doses utilizadas, tendo em vista as características físico-químicas do solo estudado.

Por outro lado, solos de textura média e arenosos, respondem à correção da acidez em um menor espaço de tempo exigindo doses menores de corretivos (MALAVOLTA \& VIOLANTE NETTO, 1989).

Nesse sentido, ROLIM (1995), instalou experimento com cana-deaçúcar em Areia Quartzosa, álica $(\mathrm{m}=64 \%)$, com baixa CTC, contendo $85 \%$ de areia, tendo aplicado calcário dolomítico, calcítico e magnesiano; magnesita e 
gesso em doses exclusivas; misturas de calcário dolomítico + gesso; misturas de calcário calcítico + magnesita e, magnesita + gesso, em 10 tratamentos, e concluiu que a aplicação de corretivos e gesso, com exceção da magnesita, promoveram um aumento das produtividades do canavial até o $3^{\text {o. }}$ corte; a mistura de gesso $(85 \%)+$ magnesita (15\%) se destacou dentre todos os tratamentos, em todos os cortes, produzindo o dobro da testemunha na $2^{\text {a. }}$ soqueira. Não houve influência dos corretivos e do gesso na qualidade da matéria prima (pol \% cana, fibra \% cana e pureza) nos 3 cortes estudados.

Ainda, MAZZA (1993) trabalhando também com cana-de-açúcar, instalou 4 experimentos, sendo 2 em cana-planta (Latossolo Vermelho Escuro textura argilosa, distrófico e Podzólico Vermelho Amarelo, textura média argilosa, distrófico) e 2 em cana-soca (areia quartzosa e Latossolo roxo-álico), aplicando-se diversos tratamentos, num esquema fatorial, utilizando-se de vários níveis de calcário e gesso. Dentre as várias conclusões, observou que o calcário e gesso, aplicados em pré-plantio e em soqueiras promoveram sensíveis incrementos nos teores de cálcio, magnésio e na saturação por bases; elevou o pH e reduziu a saturação por alumínio, restringindo parte destes efeitos à camada superficial, quando aplicado isoladamente; a ação do gesso foi efetiva em acelerar o fornecimento de cálcio e promover sua incorporação a maiores profundidades, além de estender estes efeitos ao magnésio e sulfato elevando a soma e saturação por bases, além de reduzir a saturação por alumínio nas profundidades estudadas. 
A aplicação de doses e misturas de calcário e gesso foram efetivas em elevar a produtividade da cultura nos 3 cortes. O gesso apresentou maior capacidade de elevar a produtividade da cultura a curto e médio prazos $\left(1^{\mathrm{o}}\right.$ e $2^{\mathrm{o} .}$ cortes $)$, enquanto o calcário foi mais eficiente em prolongar seus efeitos a longo prazo.

BARRETO (1991), estudou os efeitos de sistemas de rotação e níveis de calagem sobre características físicas e químicas do solo e no desenvolvimento do sistema radicular e produção de milho e salientou, dentre outras conclusões, que a calagem, mesmo após 4,5 anos da sua aplicação, ainda foi capaz de manter seu efeito residual, principalmente, sobre a neutralização do alumínio trocável e sobre os teores de cálcio e magnésio, o que promoveu maior desenvolvimento do sistema radicular e maior produção de grãos. Não alterou as propriedades físicas do solo, porém atuou em profundidade, sendo na camada de 0-20cm, onde ocorreram as maiores variações das características químicas.

MARTINS (1991), também estudou os efeitos da calagem em canade-açúcar em Latossolo Vermelho Amarelo, álico, A fraco, textura média, através da aplicação de 4 doses de calcário dolomítico incorporado antes do plantio e, gesso, $\mathrm{MgSO}_{4}$ e S elementar no sulco de plantio da variedade NA 5679 e concluiu que as doses de calcário proporcionaram aumentos lineares na produtividade da cana-de-açúcar, sendo o $\mathrm{Mg}^{2+}$ o fator mais importante da calagem. A calagem elevou o valor $\mathrm{pH}$, diminuiu o teor de $\mathrm{Al}^{3+}$ até a profundidade de $60 \mathrm{~cm}$ e aumentou os teores de $\mathrm{Ca}^{2+}$ e $\mathrm{Mg}^{2+}$ no solo. Ficou evidente a ação residual do 
calcário até 50 meses, após sua aplicação. A ação do calcário não afetou a qualidade da cana e não influenciou nos teores de $\mathrm{P}$ e $\mathrm{K}^{+}$.

QUAGGIO (1991), estudando os efeitos do calcário dolomítico e calcítico em laranjeira Valência, cultivada em Latossolo Vermelho Escuro, textura argilosa, somente atingiu a maior produtividade e lucratividade, após 4 safras, quando a acidez do solo diminuiu e a saturação por bases (V\%) ficou próxima de $60 \%$. A calagem proporcionou aumentos nos teores de sólidos solúveis e acidez do suco, através do fornecimento de $\mathrm{Mg}$ às plantas. $\mathrm{O}$ calcário dolomítico demonstrou ser fonte eficiente de Mg para a laranjeira. A calagem mesmo sendo incorporada na camada arável, reduziu consideravelmente a acidez do subsolo.

Na Flórida (EUA), trabalhos de longa duração com aplicação de calcário em solos ácidos cultivados com laranjeira Valência, desenvolvidos por ANDERSON $^{3}$, citado por OLIVEIRA (1991), produziu 41 e $61 \mathrm{~kg}$ de fruto/planta/ano, nos tratamentos sem e com calcário, respectivamente, no $7^{\text {o. }}$ ano de idade. As produções aumentaram para 162 e $323 \mathrm{~kg}$ de fruto/planta/ano, para aqueles 2 tratamentos, no $17^{\circ}$ ano de idade. $\mathrm{O}$ autor responsabilizou o menor desenvolvimento das plantas (não receberam calagem), à deficiência de cálcio ou a algum fator inibidor não identificado nos solos muito ácidos.

\footnotetext{
$3^{3}=$ ANDERSON, C.A. Fruit yields, tree size and mineral nutrition relationship in "Valencia" orange trees as affected by liming. J. Plant Nutr., 10(9-16):1907-16, 1987.
} 
No Brasil, a extensão de solos ácidos e com teores elevados de alumínio trocável é muito grande. Esses solos podem ser encontrados, com exceção da região semiárida nordestina, por todo o território brasileiro, possuindo níveis de alumínio mais ou menos elevados, dependendo de algumas condições específicas de pedogênese (OLIVEIRA, 1991).

Sendo a calagem, a maneira mais econômica de se minimizar os problemas oriundos da acidez do solo, é interessante ressaltar que as características que definem a qualidade dos corretivos são principalmente a granulometria e o teor de neutralizantes, além da forma química dos neutralizantes, da natureza geológica e do conteúdo de nutrientes (ALCARDE, 1983).

A velocidade de reação dos corretivos no solo é relativamente lenta e depende de vários fatores (EMBRAPA, 1981). A quantidade e a granulometria mais fina aceleram o processo de reação (GARGANTINI, 1974). A textura do solo e o teor de matéria orgânica influenciam a velocidade de reação (FAGÉRIA, 1984). Assim, o efeito residual do corretivo é o tempo de duração dos efeitos da calagem e isto é fundamental no manejo de solos ácidos e na economicidade do fator (FREITAS \& RAIJ, 1974; RAIJ \& QUAGGIO, 1984).

Genericamente, solos com maiores teores de matéria orgânica e argila possuem maiores CTC, necessitando de maiores quantidades de bases trocáveis para provocar um mesmo aumento de $\mathrm{pH}$ verificado em um solo com 
menor CTC. Portanto, solos mais argilosos resistem mais a mudança de $\mathrm{pH}$, apresentando maior poder tampão (VITTI, 1984).

QUAGGIO et al., (1982), avaliando o efeito residual de calcário constatou que o tratamento que recebeu 12 t/ha de calcário (PRNT \% $=57$ ), avaliado aos 30 meses após a sua incorporação, ainda apresentava no solo cerca de $1 / 3$ do produto aplicado (não reagido).

FREITAS (1987), trabalhando com latossolos de textura argilosa verificou que 30 e 48 meses após incorporação de calcário, foram suficientes para observar no solo significativas alterações nas propriedades químicas do solo, para as dosagens mais elevadas.

Segundo pesquisas desenvolvidas pela EMBRAPA (1982), quando se aplica uma dosagem correta de calcário no solo, o período mínimo de persistência do seu efeito no solo é de 5 anos, aproximadamente.

De acordo com LOPES (1983), dependendo da quantidade do corretivo aplicado, abaixo da camada arável do solo pode ocorrer considerável lixiviação de cátions trocáveis como o cálcio, magnésio e o potássio, bem como, significativas diminuições nos teores de ferro, manganês e alumínio tóxicos.

QUAGGIO et al. (1987), observaram que a lixiviação de bases trocáveis provocada pela calagem é um processo lento e gradual, ocorrendo lixiviação de cálcio e magnésio até a camada $40-60 \mathrm{~cm}$ de profundidade, logo aos 6 meses, após aplicação, havendo pequenas alterações no valor $\mathrm{pH}$. 
Dados publicados por SUZUKI (1989), quando trabalhou com incorporação profunda de calcário em Latossolo Húmico distrófico evidenciaram acréscimos de cálcio e magnésio trocáveis, diminuição do teor de alumínio trocável e elevação do pH até a profundidade de $50 \mathrm{~cm}$.

A influência da granulometria de materiais corretivos na neutralização da acidez do solo também foi estudada por CAMARGO (1972) em condições de laboratório e concluiu que os maiores aumentos nos valores $\mathrm{pH}$ foram observados logo aos 4 dias após a aplicação do corretivo com frações granulométricas menores que 70 a 140 mesh. Os maiores aumentos de $\mathrm{pH}$ encontrados foram para o solo que apresentou o menor $\mathrm{pH}$ inicial. $\mathrm{O}$ alumínio trocável foi completamente neutralizado logo aos 4 dias, nos tratamentos com calcários cujas frações granulométricas eram menores que 70 a 140 mesh.

Ficou evidente nesta revisão, que o tempo de resposta dos corretivos aplicados diretamente no solo é maior do que o observado em condições de laboratório. Além disso, esse tempo sofrerá maiores ou menores variações dependendo das características específicas de cada tipo de solo e das condições físico-químicas em que ele se encontre em determinado instante.

Outras considerações importantes retiradas da revisão bibliográfica foram:

- Os corretivos devem ser incorporados ao solo o "máximo possível" a fim de se otimizar as respostas das culturas às calagens; 
- No momento da aplicação dos corretivos deve ser lembrado o seu longo efeito residual no solo, o que poderá levar o produtor a não pensar em reduzir as dosagens recomendadas;

- Há necessidade de se obter mais resultados de pesquisa que avaliem melhor a relação existente entre as diferentes espécies de plantas e as suas tolerâncias às condições de acidez dos solos com os métodos disponíveis de recomendação de calagem.

\subsection{Respostas das culturas e do solo à aplicação de gesso em solos ácidos}

A ocorrência de excesso de alumínio e ou de deficiência de cálcio nas camadas inferiores do solo pode levar a urna redução do desenvolvimento do sistema radicular, tornando a planta mais susceptível à seca e com menor absorção de nutrientes. Estes problemas são de dificil correção pelo calcário, principalmente em pomares já instalados, no entanto, podem ser solucionados pelo gesso agrícola, devido a sua mobilidade no perfil do solo (VITTI, 1989).

Este produto tem basicamente duas origens: a) como subproduto das indústrias de mineração, conhecido como gesso; b) como subproduto da obtenção de ácido fosfórico, utilizado na fabricação de superfosfato triplo e fosfatos de amônio (MAP e DAP), mundialmente conhecido como fosfogesso (SUMNER, 1992; ALCORDO \& RECHCIGL, 1993). 
Tanto o gesso como o fosfogesso podem ser utilizados para fins agrícolas. No Brasil, estes subprodutos são conhecidos também por "gesso agrícola".

$\mathrm{O}$ gesso ou sulfato de cálcio dihidratado $\left(\mathrm{CaSO}_{4} \cdot 2 \mathrm{H}_{2} \mathrm{O}\right)$, apresentase na forma de pó branco, revelando, segundo VITTI \& MALAVOLTA (1985), a seguinte composição química aproximada:

Umidade livre

$\mathrm{CaO}$

S

$\mathrm{P}_{2} \mathrm{O}_{5}$

$\mathrm{SiO}_{2}$ (insolúveis em ácidos)

F (fluoretos)

$\mathrm{R}_{2} \mathrm{O}_{3}\left(\mathrm{Al}_{2} \mathrm{O}_{3}+\mathrm{FeO}_{3}\right)$
$15-17 \%$

$26-28 \%$

$15-16 \%$

$0,6-0,75 \%$

$1,26 \%$

$0,63 \%$

$0,37 \%$

Embora o gesso não seja muito solúvel em água e não se decomponha rapidamente no solo, ainda é mais solúvel e móvel do que o calcário e representa a forma mineral mais solúvel de cálcio (SUMNER, 1993).

Segundo MALAVOLTA (1992), a Flórida (EUA) produz anualmente 33 milhões de $t$ de gesso e, no Brasil, cerca de $10 \%$ daquele total (3 milhões de t). Estima-se que o país, no ano 2000 , tenha cerca de 80 milhões de $\mathbf{t}$ desse produto disponiveis para utilização na agricultura. $\mathrm{O}$ gesso é produzido na 
proporção de 4 a $5 \mathrm{t}$ para cada $\mathrm{t}$ de $\mathrm{P}_{2} \mathrm{O}_{5}$ de ácido fosfórico (PAOLINELLI et al., 1986).

Para MALA VOLTA \& VIOLANTE NETTO (1989) a calagem e a gessagem devem ser entendidas como operações interdependentes, pois uma não substitui a outra e ambas frequentemente se complementam. Experimentalmente, não se dispõe de uma fórmula que permita calcular a dose de gesso em função da análise do solo. Sugere-se para a cultura de citros, que a aplicação de $2,5 \mathrm{t}$ de gesso, seja suficiente para neutralizar 1 meq $\mathrm{Al}^{3+} / 100 \mathrm{~cm}^{3}$ existente no solo ou ainda, seja suficiente para elevar no solo a concentração de cálcio em $1 \mathrm{meq}$ $\mathrm{Ca}^{2+} / 100 \mathrm{~cm}^{3}$ para uma camada de solo de $20 \mathrm{~cm}$. Ainda, segunda esses autores, quando o pomar já estiver implantado, o calcário e ou gesso devem ser aplicados a lanço ( $60 \%$ na faixa adubada e $40 \%$ no meio de rua), durante os meses de abril a junho, incorporando-se com grade leve. No caso de se utilizar a subsolagem, esta operação deve ser feita após a aplicação dos produtos a fim de garantir maior penetração do corretivo e do gesso no perfil do solo.

O uso do gesso agrícola em citros também foi discutido por VITTI (1984) observando que a sua aplicação é muito importante principalmente nos casos de relações de $\mathrm{Ca} / \mathrm{Mg}$ muito baixas no solo e quando os pomares já estiverem com um nível adequado de $\mathrm{pH}$. Os citrus necessitam de uma relação $\mathrm{Ca} / \mathrm{Mg}$ no solo entre 3 e 5 , para que estes nutrientes não limitem as suas produções. 
Recomendações para gessagem, utilizando como parâmetro o teor de matéria orgânica do solo $(\% \mathrm{C} \times 1,72)$ foram apresentadas por MALAVOLTA et al. (1979).

A grande maioria das investigações, segundo VITTI \& MALAVOLTA (1985), tinha desenvolvido estudos sobre teores de alumínio apenas na camada arável, ficando a descoberto, quase por completo, os seus possíveis efeitos prejudiciais nas camadas subsuperficiais do solo, os quais restringem a expansão das raízes nesses horizontes (abaixo de 15 a $20 \mathrm{~cm}$ ), tornando as plantas susceptíveis às deficiências nutricionais e de água.

Segundo ALCARDE (1988), o gesso não é corretivo da acidez do solo pois, praticamente não altera o $\mathrm{pH}$. Ele fornece $\mathrm{Ca}^{2+}$ e $\mathrm{SO}_{4}{ }^{2-}$ para a solução do solo os quais podem ser lixiviados para camadas subsuperficiais. $\mathrm{O} \mathrm{Ca}^{2+}$ é lixiviado em maior proporção devido a sua maior concentração na solução do solo em função da adição pelo gesso. Essa lixiviação pode ser benéfica ou maléfica, dependendo da sua intensidade. Se os nutrientes catiônicos percolados permanecerem nas primeiras camadas subsuperficiais, melhoram a fertilidade da subsuperfície e estimulam o aprofundamento das raízes, permitindo às plantas maior tolerância às estiagens. Se os nutrientes forem arrastados para profundidades fora do alcance das raízes, ocorre o empobrecimento do solo. A intensidade dessa lixiviação depende do solo, da quantidade de água que o solo 
recebe por chuvas ou irrigação e da quantidade de gesso aplicada. Por estas e outras razões as doses de gesso recomendadas devem ser cuidadosas.

O cálcio aumenta praticamente de maneira uniforme no perfil do solo, enquanto o magnésio e o potássio, na maioria dos casos são deslocados da camada arável para o subsolo (QUAGGIO, 1992; VITTI et al., 1992).

A associação de gesso com calcário dolomítico é uma prática recomendada para aplicação em solos com elevada concentração de alumínio tóxico em subsuperfície podendo dispensar a incorporação profunda da mistura devido a ação eficaz do gesso em profundidade (VITTI, 1987; MALAVOLTA, 1983; PAVAN et al., 1984).

Num experimento de campo conduzido no CPAC-EMBRAPA por SOUSA et al. (1992), não observaram alterações nos teores de $\mathrm{K}^{+}$na profundidade de até $120 \mathrm{~cm}$, após 5 cultivos, com aplicação de 6 tha de gesso em um Latossolo Vermelho Escuro, textura argilosa.

A distribuição de cálcio foi estudada em diversas profundidades num Latossolo Vermelho Escuro, textura argilosa, com e sem aplicação de gesso e percolação de água na razão de $1200 \mathrm{~mm}$ de precipitação por RITCHEY et al. (1981) e observaram que o gesso aplicado na camada superficial do solo foi eficiente no deslocamento de cálcio e magnésio até a profundidade de 60 a $75 \mathrm{~cm}$ no solo. A utilização de $\mathrm{SO}_{4}{ }^{2-}$ nos solos possibilita a movimentação mais rápida 
de cálcio e de outros cátions para camadas mais profundas do solo, reduzindo as limitações de natureza química para o enraizamento profundo das plantas.

A aplicação da mistura de calcário + gesso no solo, favorece a menor retenção de $\mathrm{SO}_{4}{ }^{2-}$ na camada arável do solo devido ao aumento do $\mathrm{pH}$ pela calagem. Aumenta a retenção de $\mathrm{K}^{+}$e se o calcário apresentar um teor adequado de $\mathrm{Mg}^{2+}$, suprirá a cultura neste nutriente (SOUSA \& RITCHEY, 1986).

A solubilidade do gesso, segundo RAIJ (1992), é de tal ordem de grandeza que leva a interessante consequência prática. A lixiviação ocorre aos poucos, permitindo saturar progressivamente o subsolo. O gesso é um sal de solubilidade moderada, cerca de $2,5 \mathrm{~g} / 1$, o que equivale a uma solução de $0,03 \mathrm{~N}$. Esta referência é importante e pode ajudar na decisão da quantidade de gesso a ser aplicada nos solos.

A troca de íons é uma importante propriedade que permite aos solos reter vários nutrientes nas formas disponíveis às plantas. A propriedade de troca de íons nos solos se origina no excesso de cargas elétricas existentes nas partículas sólidas, predominando cargas negativas na camada arável da maioria dos solos.

RAIJ (1988), fez uma revisão sobre o assunto e observou alguns aspectos interessantes, dentre eles: 
- Existe a hipótese de que a lixiviação do cátion alumínio acompanha a do gesso, o que em parte pode ser favorecido pela formação dos pares iônicos ou complexos como o $\mathrm{Al} \mathrm{SO}_{4}{ }^{+}$ou fluoretos de alumínio;

- Admite que o íon $\mathrm{SO}_{4}{ }^{2-}$ seja o principal responsável pela diminuição do alumínio trocável dos solos, pelas consequências de sua reação com óxidos;

- Juntamente com o nitrato, lixivia-se uma quantidade estequiometricamente equivalente de cátions;

- A lixiviação de sulfatos nos solos tem um comportamento semelhante ao do nitrato, havendo baixa retenção em solos que não adsorvem nitratos;

- Em solos de clima temperado, o cálcio aplicado como sulfato de cálcio move-se rapidamente através dos solos;

- As cargas elétricas do solo tem um efeito importante na lixiviação de $\mathrm{Ca}^{2+} \mathrm{e}$ $\mathrm{SO}_{4}^{2-}$

- $\mathrm{O} \mathrm{Ca}^{2+}$ é muito retido no solo com valores de $\mathrm{pH}$ altos, ocorrendo o inverso com o $\mathrm{SO}_{4}^{2-}$

- Para se conhecer o processo de lixiviação do gesso, é necessário conhecer as propriedades dos solos que a afetam, a fim de se manter o sal em profundidade ao alcance das raízes.

Pesquisadores como BORKERT et al. (1987), defendem a idéia de que o calcário deve ser aplicado cerca de 60 a 90 dias antes da aplicação do gesso em havendo condições ótimas de umidade para que ocorram reações entre a 
partícula do calcário e o solo. Desta forma, o $\mathrm{Ca}^{2+}$ do $\mathrm{CaCO}_{3} \cdot \mathrm{MgCO}_{3}$ (calcário dolomítico) irá ocupar a maior parte das cargas negativas dos colóides do solo e o $\mathrm{pH}$ do solo "aumentará com a correção da acidez pelo íon $\mathrm{CO}_{3}{ }^{2-}$ ". Após essas reações, na aplicação do gesso, tanto o íon $\mathrm{Ca}^{2+}$ como o íon $\mathrm{SO}_{4}{ }^{2-}$ ficarão em maior quantidade na solução do solo. Uma vez o pH aumentado pela correção da acidez, haverá menor adsorção do $\mathrm{SO}_{4}{ }^{2-}$ que irá lixiviar no solo com as águas de percolação, levando consigo o $\mathrm{Ca}^{2+}$ e $\mathrm{o} \mathrm{Mg}^{2+}$ que se encontram dissolvidos na solução do solo, na forma iônica.

Estudos sobre a capacidade de adsorção máxima de sulfato no solo como parâmetro adicional na recomendação de gesso foi desenvolvido por YAMADA (1989) tendo concluido, dentre outros aspectos, que as doses de gesso calculadas pelos critérios do cálcio e do alumínio são em geral, superiores às doses calculadas para atingir a capacidade de adsorção máxima de sulfato no solo.

SOUSA (1989). procurou avaliar a correção da acidez subsuperficial do solo, através da aplicação de gesso e concluiu que se a saturação de $\mathrm{Al}^{3+}$ for maior que $30 \%$ e ou teor de $\mathrm{Ca}^{2+}$ for menor que $0,2 \mathrm{meq} / 100$ $\mathrm{cm}^{3}$, há boas possibilidades de resposta à sua aplicação. Observou ainda que as doses de 0,$5 ; 1,0 ; 1,5$ e 2 t/ha de gesso agrícola devem ser indicadas para solos de textura arenosa, média, argilosa e argila pesada, respectivamente.

Nos casos de solos sem problemas de acidez subsuperficial, o uso do gesso não deve ser recomendado, pois ele pode acelerar a lixiviação das bases 
$\mathrm{CaSO}_{4}{ }^{\circ}, \mathrm{MgSO}_{4}{ }^{\circ}$ e $\mathrm{K}_{2} \mathrm{SO}_{4}{ }^{\circ}$, ocasionando diminuição do nível de fertilidade do solo. Os efeitos positivos do gesso são mais pronunciados em solos com baixos teores de $\mathrm{Ca}^{2+}$ e na presença de $\mathrm{Al}^{3+}$ em profundidade. Neste caso, o gesso vai contribuir para reduzir principalmente a acidez subsuperficial e proporcionar uma maior penetração das raízes em profundidade e, consequentemente, absorver mais água e nutrientes.

Vários estudos mostram a relação direta, positiva e estreita existente entre o desenvolvimento do sistema radicular, o volume da copa e a produção de frutos em plantas cítricas (OLIVEIRA, 1991). É também bastante conhecido o efeito negativo que períodos de "veranico" provocam em plantas cítricas com sistema radicular pouco desenvolvido. Desta forma, a aplicação de misturas de calcário dolomítico + gesso, seguida por uma operação de subsolagem e gradagem vai acelerar a lixiviação do gesso no perfil do solo, diminuir o efeito tóxico causado pelo alumínio existente na subsuperfície e promover maior desenvolvimento radicular das plantas cítricas.

Os trabalhos de pesquisa sobre a aplicação exclusiva de gesso em citros não tem demonstrado a mesma eficiência obtida com as misturas de calcário e gesso.

Trabalho recente de DONADIO et al. (1994), sobre o uso exclusivo do gesso e misturas de gesso + calcário dolomítico em laranjeira Pera, desde 1985, permitiu observar que as menores produções foram obtidas no tratamento 
testemunha (sem corretivos) e no tratamento que recebeu a aplicação de gesso isolada; As maiores produções ocorreram nos tratamentos com aplicação isolada do calcário e da mistura de calcário + gesso. Tomando-se por base as produções obtidas nas safras 91 a 93, a aplicação isolada de calcário e a mistura de calcário + gesso (50:50), produziram em média 1 caixa/planta a mais em relação à aplicação isolada de gesso e 0,5 caixa/planta a mais em relação à testemunha. A qualidade do fruto, no geral foi pouco afetada. Os efeitos positivos do calcário ou da alta exigência dos citros em $\mathrm{Ca}^{2+}$, ou ainda pelo uso do gesso, que enriquece o perfil do solo em $\mathrm{Ca}^{2+}$ e diminui a saturação por alumínio, provavelmente sejam os responsáveis diretos pelos incrementos obtidos nas produtividades. 


\section{MATERIAL E MÉTODOS}

O experimento foi instalado em 20/07/92 na Fazenda Colorado, propriedade do Sr. Lair Antonio de Souza, no município de Araras-SP, acesso

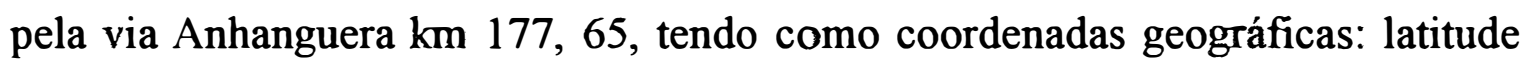
$22^{\circ}$ e $18^{\prime}$ Sul, longitude $47^{\circ}$ e $23^{\prime} \mathrm{W}$ e altitude média de $617 \mathrm{~m}$.

\subsection{Clima e Solo}

O clima da região é classificado, de acordo com Sistema Internacional de Köppen, como CWa, ou seja, clima mesotérmico de inverno seco, em que a temperatura média anual do mês mais frio é inferior a $18^{\circ} \mathrm{C}$ e a do mes mais quente ultrapassa os $22^{\circ} \mathrm{C}$. A precipitação média anual é de $1400 \mathrm{~mm}$. A distribuição pluvial segue o regime típico das zonas tropicais de baixa altitude, ou seja, verão chuvoso e inverno seco. O balanço hídrico, segundo THORNTWAIT apresenta um excedente hídrico de $425 \mathrm{~mm}$ entre os meses de dezembro a março e uma deficiência hídrica de $20 \mathrm{~mm}$ entre os meses de abril a setembro (OLIVEIRA \& ROTTA, 1973). 
Na tabela 1 estão os dados de precipitações pluviométricas (mm) mensais, registrados na Fazenda Colorado (Araras, SP), relativos ao período: 1992 a 1994, época em que foi realizado este trabalho, e que podem ser comparados com as médias mensais dos últimos 10 anos (Período: 1985 a 1994), também coletados no mesmo local.

TABELA 1 - Dados de precipitações pluviométricas $(\mathrm{mm})$ registrados pela Fazenda Colorado (Araras-SP) período: 1992 a 1994.

\begin{tabular}{|c|c|c|c|c|c|c|c|c|c|c|c|c|c|}
\hline \multirow[b]{2}{*}{ ANO } & \multicolumn{12}{|c|}{ PRECIPIT AÇŌES PLUVIOMETRICAS (mm) MENSAIS } & \multirow[b]{2}{*}{ Total } \\
\hline & Jan & Fev & Mar & Abr & Mai & Jun & Jul & Ago & Set & Out & Nov & Dez & \\
\hline 1992 & 131 & 230 & 222 & 35 & 135 & - & 96 & 22 & 115 & 249 & 227 & 196 & 1.658 \\
\hline 1993 & 257 & 584 & 125 & 116 & 131 & 47 & 10 & 37 & 188 & 115 & 98 & 196 & 1.904 \\
\hline 1994 & 267 & 154 & 122 & 16 & 99 & 52 & 33 & - & - & 160 & 185 & 261 & 1.349 \\
\hline$\left({ }^{*}\right)$ & 236 & 255 & 204 & 99 & 87 & 21 & 34 & 25 & 69 & 134 & 162 & 216 & 1.546 \\
\hline
\end{tabular}

O solo onde foi instalado o experimento é do tipo Latossolo Vermelho Escuro (LEarg), álico, A moderado, textura argilosa - Unidade Limeira (Typic HAPLORTHOX) e com aptidão agrícola satisfatória para culturas anuais e boa para culturas de ciclo longo, pastagens e reflorestamento. Este solo foi classificado quanto a declividade em ligeira à moderada $\mathrm{e}$ quanto à disponibilidade de nutrientes, em nula à forte (OLIVEIRA \& BERG, 1985). 
Estes solos são bastante profundos e uniformes, com o horizonte A atingindo cerca de $40 \mathrm{~cm}$. Tem um teor de argila entre 50 e $60 \%$ e abaixo desse horizonte, a porcentagem de argila aumenta para valores maiores que 50\%.

Por ocasião da escolha da área do experimento foram coletadas 3 amostras de solo compostas, nas profundidades de $0-20 \mathrm{~cm}, 20-40 \mathrm{~cm}$ e $40-60$ cm, cujos resultados analíticos são apresentados na tabela 2 .

TABELA 2 - Resultados analíticos das amostras de solo coletadas em 3 profundidades, antes da instalação do experimento ${ }^{(1)}$.

\begin{tabular}{|c|c|c|c|c|c|c|c|c|c|c|c|c|}
\hline $\begin{array}{l}\text { Profundidade } \mathrm{e}^{(3)} \\
\qquad(\mathrm{cm})\end{array}$ & (3) $\begin{array}{r}\mathrm{pH} \\
\mathrm{CaCl}_{2}\end{array}$ & $\begin{array}{l}\text { M.O. } \\
\text { g. dm }\end{array}$ & & $\frac{\mathrm{S}-\mathrm{SO}_{4}{ }^{2-(2)}}{\mathrm{mg} \cdot \mathrm{dm}^{-3}}$ & $\underline{\mathrm{K}^{+}}$ & $\mathrm{Ca}^{2+}$ & $\frac{\mathrm{Mg}^{2}}{\mathrm{mmo}}$ & $\frac{\mathrm{Al}^{3+}}{\mathrm{l}_{\mathrm{c}} \mathrm{dm}^{-3}}$ & $\mathrm{H}^{+}+\mathrm{Al}^{3+}$ & ${ }^{+} \mathrm{SB}$ & $\mathrm{T}$ & $\begin{array}{l}\mathrm{V} \\
\%\end{array}$ \\
\hline $0-20$ & 4,2 & 33 & 15 & 112 & 2,8 & 12 & 7 & 5,6 & 52 & 27 & 74 & 34 \\
\hline $20-40$ & 3,9 & 33 & 6 & 99 & 1,9 & 7 & 3 & 11,3 & 98 & 23 & 110 & 19 \\
\hline $40-60$ & 4,3 & 22 & 2 & 74 & 1,0 & 8 & 4 & 11,7 & 47 & 19 & 60 & 29 \\
\hline
\end{tabular}

(1) = Os resultados analiticos foram obtidos segundo a metodologia descrita por RAIJ et al., 1987.

(2) $=\mathrm{Os}$ teores de $\mathrm{S}_{-} \mathrm{SO}_{4}{ }^{2-}$ foram determinados segundo a metodologia descrita por VITT1, 1988.

${ }^{(3)}=$ Cada uma das 3 profundidades representou I amostra de solo, composta por 30 subamostras.

Trata-se de um solo ácido, com baixa relação $\mathrm{Ca} / \mathrm{Mg}$ (especificamente para a cultura de citros) e com razoável poder tampão. 
3.2. Delineamento experimental, tratamentos e detalhamento das parcelas.

O experimento foi instalado segundo um delineamento experimental em blocos casualizados com 7 tratamentos por bloco e 6 repetições, portanto, 7 parcelas/bloco, totalizando 42 parcelas (Tabela 3). Cada parcela foi composta por 10 plantas (laranjeiras) espaçadas por $8 \mathrm{~m}$ nas entrelinhas e $7 \mathrm{~m}$ entre as plantas. As plantas "tratadas" foram alternadas em linha com outras plantas com a finalidade de se evitar possíveis problemas de contaminação entre as parcelas e com isto, aumentar o nível de confiabilidade nos resultados. Estas plantas receberam adubações básicas e tratamentos fitossanitários de rotina e tiveram suas colheitas realizadas separadamente. A área total do experimento, incluindo as bordaduras, foi de $50.400 \mathrm{~m}^{2}\left(900\right.$ plantas $\left.\mathrm{x} 56 \mathrm{~m}^{2} / \mathrm{cada}=50.400 \mathrm{~m}^{2}\right)$.

TABELA 3 - Quadro da análise de variância.

\begin{tabular}{cc}
\hline Causas de variação & Graus de liberdade \\
$(\mathrm{CV})$ & $(\mathrm{GL})$ \\
\hline Tratamentos (7) & 6 \\
Blocos (6) & 5 \\
Residuo & 30 \\
Total & 41 \\
\hline
\end{tabular}


Em todos os resultados obtidos foram aplicados o teste "F" de significância estatística e o teste de "Tukey" ao nível de 5\% de probabilidade para as médias dos tratamentos.

Todos os resultados analíticos e de produção apresentados nas tabelas deste trabalho representam médias de 6 repetições.

$\mathrm{Na}$ tabela 4 , estão os tipos de tratamentos adotados e suas caracterizações.

A adubação de produção foi recomendada pelo G.P.A.C.C. (1990), que fez as indicações de adubação baseadas nos teores de nutrientes existentes no solo e nas folhas, na produção esperada e no tipo de porta enxerto. As adubações com micronutrientes foram feitas através dos tratamentos fitossanitários ou de adubações foliares aplicadas durante o período de vegetação das plantas.

Os cálculos das quantidades de calcário indicadas foram calculados para uma profundidade de $0-20 \mathrm{~cm}$, seguindo-se o critério da saturação por bases de acordo com a equação 1, recomendada pelo G.P.A.C.C. (1990).

$\mathrm{NC}=\frac{\mathrm{CTC}\left(\mathrm{V}_{2}-\mathrm{V}_{1}\right)}{10 \mathrm{PRNT}} \quad$ (1), onde:

$\mathrm{NC}=$ necessidade de calagem, expressa $\mathrm{em} \mathrm{t/ha;}$

CTC = capacidade de troca de cátions do solo em mmol $_{c} \mathrm{dm}^{-3}$;

$\mathrm{V}_{\mathrm{l}}=$ saturação por bases atual do solo, da camada de $0-20 \mathrm{~cm}$, expressa em \%;

$\mathrm{V}_{2}=$ saturação por bases desejada para os citros, expressa em \%;

PRNT $=$ poder relativo da neutralização total do calcário, expresso em \%; 
TABELA 4 - Tratamentos e suas caracterizações.

\begin{tabular}{lll}
\hline$N^{0 .}$ & Tratamentos & Caracterização ${ }^{(2)}$ \\
\hline 1 & $\mathrm{~T}_{1}{ }^{(1)}$ & $\mathrm{AB}$ \\
2 & $\mathrm{~T}_{2}$ & $\mathrm{AB}+\mathrm{CD}$ (exclusivo) \\
3 & $\mathrm{~T}_{3}$ & $\mathrm{AB}+\mathrm{CC}$ (exclusivo) \\
4 & $\mathrm{~T}_{4}$ & $\mathrm{AB}+\mathrm{CM}$ (exclusivo) \\
5 & $\mathrm{~T}_{5}$ & $\mathrm{AB}+(50 \%$ de CD $+50 \%$ de CC) - Relação 1:1 \\
6 & $\mathrm{~T}_{6}$ & $\mathrm{AB}+(2 / 3$ de CD $+1 / 3$ de CC) - Relação 2:1 \\
7 & $\mathrm{~T}_{7}$ & $\mathrm{AB}+(75 \%$ de CD $+25 \%$ de gesso $)-$ Relação 3:1 \\
\hline
\end{tabular}

(I) = Testemunha;

(2) $=A B$ foi indicada com base nas análises de solo e de planta e, a NC foi calculada para $V \%=70 \%$.

\section{LEGENDA:}

$\mathrm{AB}=$ adubação básica para manutenção da cultura (fator não limitante), NPK + micronutrientes.

$\mathrm{CD}=$ calcário dolomítico .

$\mathrm{CC}=$ calcário calcítico.

$\mathrm{CM}=$ calcário magnesiano.

$\mathrm{NC}=$ necessidade de calcário

$\mathrm{V} \%=$ porcentagem de saturação por bases

A faixa adequada de saturação por bases para os citros $\left(V_{2}\right)$ encontra-se entre 60 e $70 \%$.

Utilizou-se $\mathrm{V}_{2}=70 \%$ para todos os cálculos de recomendação de calcário dolomítico, calcítico e magnesiano. 
Os calcários e gesso usados no experimento foram fornecidos pela firma "Sociedade Extrativa Dolomia Ltda", com sede comercial em São Paulo e o setor de extração e processamento em Taubaté/SP. Os resultados analíticos desses materiais estão apresentados na tabela 5 .

TABELA 5 - Resultados analíticos dos corretivos e do gesso fornecidos pela firma "Sociedade Extrativa Dolomia Ltda".

\begin{tabular}{lccc}
\hline \multicolumn{1}{c}{ Produto } & $\begin{array}{c}\text { Óxido de cálcio } \\
(\% \mathrm{CaO})\end{array}$ & $\begin{array}{c}\text { Óxido de } \\
\text { magnésio } \\
(\% \mathrm{MgO})\end{array}$ & $\begin{array}{c}\text { Poder relativo de } \\
\text { neutralização total } \\
(\% \text { PRNT })\end{array}$ \\
\hline Calcário dolomítico & 27 & 17 & 90 \\
Calcário calcítico & 52 & 05 & 93 \\
Calcário magnesiano & 28 & 12 & 75 \\
Gesso agrícola & 26 & - & - \\
\hline
\end{tabular}

Aplicou-se a equação 1 para os 3 corretivos e obteve-se as seguintes recomendações:

Calcário dolomítico $=2,95 \mathrm{t} / \mathrm{ha}\left(\mathrm{T}_{2}\right)$

Calcário calcítico $=2,86 \mathrm{t} / \mathrm{ha}\left(\mathrm{T}_{3}\right)$

Calcário magnesiano $=3,55 \mathrm{t} / \mathrm{ha}\left(\mathrm{T}_{4}\right)$

Para o cálculo das quantidades de calcários utilizadas nas proporções: $1: 1 ; 2: 1$ e $3: 1$, tratamentos $T_{5}, T_{6}$ e $T_{7}$, respectivamente, aplicou-se a mesma equação (1), diferindo apenas quanto ao cálculo da \% PRNT que nestes 3 
casos utilizou-se um PRNT médio. Seja por exemplo o tratamento $T_{5}$ : PRNT médio $=(0,5 \times 90 \%)+(0,5 \times 93 \%)=91,5 \%$.

Desta forma, no tratamento $T_{5}$ foram aplicadas 1,45 tha $(50 \%$ de calcário dolomítico $)+1,46$ t/ha ( $50 \%$ de calcário calcítico), totalizando $2,91 \mathrm{t} / \mathrm{ha}$, e no tratamento $\mathrm{T}_{6}$, foram aplicados $1,99 \mathrm{t} / \mathrm{ha}(2 / 3$ de calcário dolomítico) $+0,99$ t/ha (1/3 de calcário calcítico) totalizando $2,98 \mathrm{t} / \mathrm{ha}$.

Para o caso específico do tratamento $T_{7}$, convém lembrar que $o$ valor do PRNT médio é igual a $67,5 \%$ ou seja $(0,75 \times 90 \%=67,5 \%)$, uma vez que o PRNT do gesso é igual a zero. Assim, para o tratamento $T_{7}$ foram aplicadas 3,95 t/ha da mistura de calcário dolomítico + gesso, sendo: 2,96 t/ha de calcário dolomítico $(75 \%)+1$ t/ha de gesso agrícola $(25 \%)$. .

Para se calcular a necessidade de gesso (NG), usando-se a metodologia descrita por MALAVOLTA (1991), observa-se duas situações:

$1^{\mathrm{a}}$ ) Quando a participação do cálcio na CTC efetiva (CTCe) for menor que $40 \%$ ou seja,

$$
\frac{\mathrm{Ca}^{2+}}{\mathrm{Al}^{3+}+\mathrm{Ca}^{2+}+\mathrm{Mg}^{2+}+\mathrm{K}^{+}}
$$

Neste caso, aplicando-se a equação 2 , o valor encontrado foi de $30,17 \%$, portanto $<40 \%$.

$2^{\mathrm{a}}$ ) Quando a saturação por alumínio for superior a $20 \%$ ou seja,

$$
\frac{\mathrm{Al}^{3+}}{\mathrm{Al}^{3+}+\mathrm{K}^{+}+\mathrm{Ca}^{+}+\mathrm{Mg}^{2+}}
$$


Neste caso, aplicando-se a equação 3 , o valor encontrado foi de $48,71 \%$, portanto $>20 \%$.

Conforme a metodologia descrita, ocorrendo as duas condições, ou uma delas, calcula-se a dose de gesso por:

$\mathrm{NG}=\left(0,4 \mathrm{CTCe}-\mathrm{Ca}^{2+}\right) \times 0,25$

(4) ou,

$\mathrm{NG}=\left(\mathrm{Al}^{3+}-0,2 \mathrm{CTCe}\right) \times 0,25$

(5), onde:

$\mathrm{NG}=$ necessidade de gesso em $\mathrm{t} / \mathrm{ha}$;

$\mathrm{CTCe}=$ capacidade de troca cationica efetiva .

Para os cálculos, foram utilizados os resultados das análises químicas obtidas nas amostras de solo coletadas antes da instalação do experimento, na profundidade de $20-40 \mathrm{~cm}$.

Neste caso, após terem sido satisfeitas as duas situações expressas pelas equações 2 e 3, e optar-se pela utilização da equação 4, obteve-se:

$N G=(0,4 \times 23,2-7) \times 0,25=0,57$

$\underline{\mathrm{NG}=0,57 \text { t/ha de gesso agrícola }}$ (A) e, pela equação 5 , obteve-se:

$N G=(11,3-0,2 \times 23,2) \times 0,25$

$\mathrm{NG}=1,66 \mathrm{t} / \mathrm{ha}$ de gesso agrícola $(\mathrm{B})$

Considerando-se que as 2 situações expressas pelas equações 2 e 3 foram satisfeitas, optou-se apenas para efeito de cálculo, pela dose média obtida entre $A$ e $B$, e que foi igual a 1,12 t/ha de gesso agrícola, valor semelhante a 1 
tha, determinada anteriormente $\left(3,95\right.$ tha da mistura $-T_{7}$, sendo: 2,95 tha de calcário dolomítico +1 tha de gesso agrícola), através da equação 1 .

\section{3 - Planta}

Utilizou-se como planta teste a laranjeira Hamlin sobre o portaenxerto limoeiro Cravo. Este cultivar foi plantado em janeiro de 1982.

\section{4. - Fertilizantes}

Conforme salientado no item 3.2., os fertilizantes aplicados referemse às adubações de produção e foram calculadas com base nas recomendações técnicas fornecidas pelo G.P.A.C.C. (1990) os quais se basearam nos teores de nutrientes existentes no solo e nas folhas e, na produção esperada.

Os adubos sólidos foram aplicados mecanicamente em faixas atingindo toda a projeção da copa da laranjeira, em 2 períodos:

10.) Safra 92/93 - $700 \mathrm{~g} /$ planta/vez da fórmula $25-10-15$ nos meses de setembro e dezembro/92 e fevereiro/93;

20.) Safra 93/94 - $1000 \mathrm{~g} /$ planta/vez da fórmula 15-05-10 nos meses de setembro e dezembro/93 e fevereiro/94. 
As aplicações de micronutrientes foram feitas sistematicamente nos meses de fevereiro, setembro e novembro de cada ano, através de pulverizações com sulfato de zinco, sulfato de manganês, ácido bórico, enxôfre elementar na forma líquida e uréia.

Por ocasião das aplicações dos defensivos agrícolas a fim de manter o controle fitossanitário da cultura, também foram adicionados produtos contendo micronutrientes para corrigir possíveis deficiências.

\subsection{Instalação do Experimento.}

\subsubsection{Amostragem inicial de solo e folha}

No mês de Abril/92 foram coletadas amostras de solo nas profundidades de $0-20 \mathrm{~cm}, 20-40 \mathrm{~cm}$ e $40-60 \mathrm{~cm}$, na projeção da copa das laranjeiras. Cada amostra foi composta por 30 sub-amostras colhidas aleatoriamente na Unidade Experimental. Os resultados analíticos estão na Tabela 2, do item 3.1.

Simultaneamente, foram colhidas amostras de folhas seguindo a metodologia descrita pelo G.P.A.C.C. (1990), com a finalidade de se fazer uma avaliação preliminar nos teores de macro e micronutrientes na planta. 


\subsubsection{Critérios adotados para a instalação do experimento}

As parcelas foram instaladas no campo, segundo o delineamento experimental apresentado no item 3.2, em 20/07/92.

Os corretivos e o gesso foram distribuídos nas parcelas à lanço, manualmente. Após a sua distribuição, fez-se uma dupla operação de subsolagem nas entrelinhas da cultura a uma profundidade média de $60 \mathrm{~cm}$, através de subsolador de 3 hastes. Utilizando-se de grade niveladora leve, fez-se 2 aplicações cruzadas, na linha e na entrelinha da cultura, a fim de incorporar os produtos.

\subsubsection{Controle fitossanitário e de ervas daninhas}

Aplicaram-se pulverizações sistemáticas de defensivos agrícolas em caráter preventivo e curativo a fim de manter o controle fitossanitário da cultura.

Mensalmente, durante o período das chuvas (outubro a maio), foram realizadas capinas ou roçadas nas entrelinhas das laranjeiras e aplicado o herbicida roundup em faixa atingindo a projeção da copa da laranjeira a fim de se diminuir a concorrência em nutrientes pelas ervas daninhas. 


\subsection{Critérios utilizados para amostragem de solo.}

Durante os meses de abril/93 e abril/94 foram feitas as amostragens de solo nas profundidades de $0-20 \mathrm{~cm}, 20-40 \mathrm{~cm}$ e $40-60 \mathrm{~cm}$. As análises químicas de solo foram feitas para se analisar alguns parâmetros no perfil do solo até a profundidade de $60 \mathrm{~cm}$.

Convém lembrar que a parcela foi composta por 10 laranjeiras sendo que as 8 plantas centrais representaram as "plantas úteis". Coletou-se amostras de solo nas 3 profundidades, na região da projeção da copa de cada uma das 8 laranjeiras, alternando-se as posições de amostragem entre as plantas. Desta forma, obteve-se 3 amostras compostas por parcela, sendo uma para cada profundidade. Cada amostra de solo foi composta por 8 subamostras.

\subsection{Critérios utilizados para amostragem de folha.}

As 8 plantas úteis de cada parcela foram amostradas em 2 épocas: março/93 (1a. época de amostragem) e março/94 (2a. época de amostragem).

Coletou-se a $3^{\text {a. }}$ e $4^{\text {a. }}$ folhas a partir do fruto, gerada na primavera, com aproximadamente 6 meses de idade, em ramos com frutos de $4 \mathrm{~cm}$ de diâmetro, aproximadamente e em número de 8 folhas por planta, 2 em cada quadrante e na altura mediana da copa. Cada amostra foi composta por 64 folhas 
colhidas nas 8 plantas úteis de cada uma das parcelas. As folhas foram acondicionadas em sacos plásticos e encaminhadas no mesmo dia para o laboratório onde foram feitas as análises de rotina (macro e micronutrientes).

\subsection{Critérios utilizados para amostragem de frutos.}

Colheu-se 1 fruto por laranjeira nas 8 plantas "úteis" de cada parcela, na altura mediana da copa, procurando-se alternar a posição de coleta do fruto na linha da cultura. Cada amostra foi composta por 8 frutos colhidos aleatoriamente na parcela. No laboratório foram determinados as dimensões físicas dos frutos (peso unitário em gramas e, comprimento e diâmetro em mm) e as análises qualitativas do suco (\% suco, \% acidez, teor de sólidos solúveis e ratio), para as duas épocas de amostragens: julho/93 e julho/94.

\subsection{Critérios utilizados na colheita das laranjas}

As colheitas foram feitas em duas épocas (safras). A primeira no período de 16 a 19/07/93 e a segunda no período de 26 a 28/06/94.

As laranjas produzidas pelas 8 plantas "úteis" de cada parcela foram colhidas e acondicionadas em caixas plásticas (padrão de colheita das indústrias). Fez-se a padronização do volume de laranja em todas as caixas de todas as 
parcelas. Pesou-se, aleatoriamente, 10 caixas vazias e com laranja com a finalidade de se obter:

a) peso médio das caixas vazias; e

b) peso médio das caixas com laranja.

Assim, procurou-se evitar erros de pesagens aplicando-se um único critério de avaliação.

Conhecido o número de caixas padronizadas com laranja por parcela, multiplicado pelo peso médio líquido, obteve-se o peso total das laranjas de cada parcela.

As produções foram avaliadas através de 2 parâmetros: $\mathrm{n}^{\mathrm{o}}$ de caixas/planta (caixas de $40,8 \mathrm{~kg}$ ) e a produtividade, expressa em t/ha. 


\section{RESULTADOS E DISCUSSÃO}

\subsection{Efeitos dos tratamentos nas propriedades químicas do solo}

\subsection{1. $\mathrm{pH}, \mathrm{Al}^{3+}$ trocável, $\mathrm{H}^{+}+\mathrm{Al}^{3+}$ e porcentagem de saturação por $\mathbf{A l}^{3+}(\mathbf{m} \%)$.}

Nas tabelas 6 e 7 encontram-se os valores de $\mathrm{pH}$ determinados em solução de $\mathrm{CaCl}_{2}$ 0,01 M.L $\mathrm{L}^{-1}$, nas profundidades de $0-20 \mathrm{~cm} ; 20-40 \mathrm{~cm}$ e $40-60$ $\mathrm{cm}$ respectivamente para a $1^{\text {a. }}$ e $2^{\text {a }}$ épocas de amostragem de solo. Usou-se a solução de $\mathrm{CaCl}_{2}$ 0,01 M.L ${ }^{-1}$ como solvente porque se trata de solução extratora de cátions e promoverá uma redução dos valores de $\mathrm{pH}$, em relação aos valores de $\mathrm{pH}$ determinados em água. Este efeito se deve ao deslocamento de íons $\mathrm{H}^{+}$e $\mathrm{Al}^{3+}$ adsorvidos às partículas de solo, através do $\mathrm{Ca}^{2+}$ existente na solução. Uma segunda causa do abaixamento dos valores de $\mathrm{pH}$, segundo $\mathrm{RAIJ}^{4}$, citado por CARVALHO (1994), trata-se da compressão da dupla camada elétrica difusa, fazendo com que o gradiente de concentração dos íons $\mathrm{H}^{+}$, entre a solução de

\footnotetext{
${ }^{4}$ RAIJ, B. van. Propriedades eletroquímicas de solos. In: Simpósio Avançado de Química e Fertilidade do Solo, 1. , Piracicaba, 1986. Anais. Campinas, Fundação Cargill, 1986. p. 9-41.
} 
Tabela 6- Valores de pH em 3 profundidades de solo (1a. época de amostragem safra 1992/93).

\begin{tabular}{cccc}
\hline TRATAMENTO & \multicolumn{3}{c}{ PROFUNDIDADE (cm) } \\
\cline { 2 - 4 } & $0-20$ & $20-40$ & $40-60$ \\
\hline T1 & 4,56 & 4,16 & 4,41 \\
T3 & 4,41 & 4,10 & 4,25 \\
T4 & 4,65 & 4,13 & 4,33 \\
T5 & 4,60 & 4,31 & 4,25 \\
T6 & 4,73 & 4,30 & 4,38 \\
T7 & 4,58 & 4,05 & 4,21 \\
F & 4,56 & 4,03 & 4,30 \\
dms(5\%) & $0,42 \mathrm{NS}$ & $2,13 \mathrm{NS}$ & $0,54 \mathrm{NS}$ \\
CV(\%) & 0,65 & 0,34 & 0,44 \\
\hline
\end{tabular}

\section{LEGENDA:}

$$
\begin{array}{ll}
\mathrm{T} 1=\text { Testemunha } & \mathrm{T} 5=50 \% \text { calc. dolomítico }+50 \% \text { calc. calcítico } \\
\mathrm{T} 2=\text {.Calcário dolomítico } & \mathrm{T} 6=2 / 3 \text { calc. dolomítico }+1 / 3 \text { calc. calcítico } \\
\mathrm{T} 3=\text { Calcário calcítico } & \mathrm{T} 7=75 \% \text { calc. dolomítico }+25 \% \text { gesso } \\
\mathrm{T} 4=\text { Calcário magnesiano } &
\end{array}
$$


Tabela 7 - Valores de $\mathrm{pH}$ em 3 profundidades de solo (2a. época de amostragem safra 1993/94).

\begin{tabular}{cccc}
\hline TRATAMENTO & \multicolumn{3}{c}{ PROFUNDIDADE $(\mathrm{cm})$} \\
\cline { 2 - 4 } & $0-20$ & $20-40$ & $40-60$ \\
\hline T1 & 4,18 & 3,96 & 3,88 \\
T3 & 4,11 & 3,83 & 3,85 \\
T4 & 4,31 & 4,03 & 4,03 \\
T5 & 4,41 & 3,95 & 4,05 \\
T6 & 4,16 & 3,85 & 3,80 \\
T7 & 4,20 & 3,86 & 3,86 \\
F & 4,33 & 3,88 & 3,81 \\
dms(5\%) & $0,68 \mathrm{NS}$ & $0,70 \mathrm{NS}$ & $1,29 \mathrm{NS}$ \\
CV(\%) & 0,58 & 0,38 & 0,39 \\
\hline
\end{tabular}

\section{LEGENDA:}

$\mathrm{T} 1=$ Testemunha

$\mathrm{T} 2=$.Calcário dolomítico

$\mathrm{T} 3$ = Calcário calcítico

$\mathrm{T} 4=$ Calcário magnesiano
$\mathrm{T} 5=50 \%$ calc. dolomítico $+50 \%$ calc. calcítico

$\mathrm{T} 6=2 / 3$ calc. dolomítico $+1 / 3$ calc. calcítico

$\mathrm{T} 7=75 \%$ calc. dolomítico $+25 \%$ gesso 
equilíbrio e a superfície se reduza, de forma que o $\mathrm{pH}$ seja diminuído por se aproximar do $\mathrm{pH}$ da superfície das partículas.

Os resultados das análises estatísticas revelados pelos testes "F" e de "Tukey" a 5\% não foram significativos para nenhuma das profundidades, nas duas épocas avaliadas. Observa-se que as variações dos valores de $\mathrm{pH}$ entre as

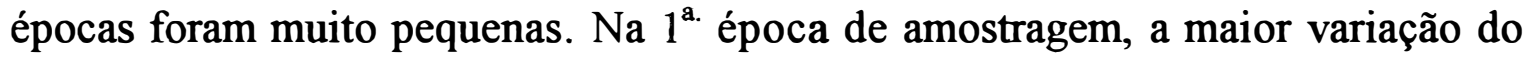
$\mathrm{pH}$ ocorreu na profundidade de $0-20 \mathrm{~cm}$, entre o maior valor $(\mathrm{pH}=4,73)$ e o menor $(\mathrm{pH}=4,41)$, portanto um gradiente da ordem de 0,32 unidades (não significativa). $\mathrm{Na} 2^{\text {a. }}$ época, este fato se repetiu, ocorrendo uma variação de 0,30 unidades entre o maior valor $(\mathrm{pH}=4,41)$ e o menor valor $(\mathrm{pH}=4,11)$.

Nas 2 épocas de amostragem, observou-se que os valores de $\mathrm{pH}$ diminuíram com o aumento da profundidade.

Um aspecto interessante a ressaltar é com relação à pequena acidificação do solo observada entre a $1^{\text {a. }}$ e $2^{\text {a. }}$ épocas de amostragem. Este fato também foi observado por QUAGGIO (1991), sugerindo que a acidificação do solo se deva ao uso de fertilizantes nitrogenados, principalmente aqueles portadores de $\mathrm{N}$ na forma amoniacal e amídica e, pela aplicação de $\mathrm{S}$ elementar na planta na forma de pulverização para o controle de ácaros. O excesso de $\mathrm{S}$ elementar cai no solo e pode acidificá-lo. WANDER ${ }^{5}$, citado por QUAGGIO

\footnotetext{
${ }^{5}=$ WANDER, I.W. Sources contributing to subsoil acidity in Florida citrus groves. Procoedings of the American Society for Horticultural Science, Alexandria, 64:105-10, 1954.
} 
(1991), também realizou diversos estudos sobre a acidificação dos solos em pomares da Flórida e observou que a acidificação era causada por estas fontes de acidez e atingia profundidades de até 1 metro. Mesmo tendo aplicado elevadas doses de calcários, não conseguiu recuperar a fertilidade dos solos estudados, principalmente nas camadas do solo mais profundas.

QUAGGIO (1991), observou que uma alternativa para se tentar reduzir a acidificação na faixa adubada é a ampliação desta faixa, o que diminuirá a concentração de sais adicionados na projeção da copa das plantas.

Os teores de $\mathrm{Al}^{3+}$ encontrados no solo, nas 3 profundidades estudadas para cada uma das épocas de amostragens, estão apresentados nas tabelas 8 e 9. Na figura 1, estão representados os efeitos dos tratamentos em função das profundidades e das épocas de amostragens com a finalidade de se evidenciar alguns efeitos específicos de determinados tratamentos.

Os teores de $\mathrm{Al}^{3+}$ trocável variaram significativamente em todas as profundidades do solo, nas duas épocas de amostragens analisadas.

Como era de se esperar, os maiores teores de $\mathrm{Al}^{3+}$ foram encontrados na parcela testemunha, principalmente na profundidade de $20-40 \mathrm{~cm}$ da $1^{\text {a. }}$ e $2^{\text {a. }}$ épocas de amostragem. As parcelas tratadas com calcário calcítico apresentaram os menores teores de $\mathrm{Al}^{3+}$ nas 3 profundidades, na $1^{\text {a. }}$ época de avaliação. Os tratamentos $T_{3}, T_{5}, T_{6}$ e $T_{7}$ apresentaram nesta época, os menores teores de $\mathrm{Al}^{3+}$, diferindo significativamente da testemunha a $1 \%$ de probabilidade. 
Tabela 8 - Teores de $\mathrm{Al}^{3+}\left(\mathrm{mmol}_{\mathrm{c}} \cdot \mathrm{dm}^{-3}\right)$ em 3 profundidades de solo (1a. época de amostragem - safra 1992/93).

\begin{tabular}{cccc}
\hline TRATAMENTO & \multicolumn{3}{c}{ PROFUNDIDADE (cm) } \\
\cline { 2 - 4 } & $0-20$ & $20-40$ & $40-60$ \\
\hline T1 & $11,1 A$ & $12,1 A$ & $8,5 A B$ \\
T2 & $9,3 A B$ & $9,3 A B$ & $9,3 A B$ \\
T3 & $3,5 C$ & $8,3 B$ & $6,1 B$ \\
T4 & $7,3 A$ & $12,3 A$ & $7,3 A B$ \\
T5 & $4,3 C$ & $11,5 A B$ & $10,0 A B$ \\
T6 & $3,6 C$ & $12,1 A$ & $11,3 A B$ \\
T7 & $3,5 C$ & $12,5 A$ & $12,1 A$ \\
F & $34,04^{* *}$ & $7,05^{* *}$ & $4,92^{* *}$ \\
dms(1\%) & 2,90 & 3,30 & 5,10 \\
CV(\%) & 21,73 & 13,72 & 25,34
\end{tabular}

Médias seguidas de mesmas letras maiúsculas, na vertical, não diferem estatisticamente pelo teste de Tukey a $1 \%$.

LEGENDA:

$\mathrm{T} 1=$ Testemunha

$\mathrm{T} 2=$.Calcário dolomítico

$\mathrm{T} 3$ = Calcário calcítico

T4= Calcário magnesiano
$\mathrm{T} 5=50 \%$ calc. dolomítico $+50 \%$ calc. calcítico $\mathrm{T} 6=2 / 3$ calc. dolomítico $+1 / 3$ calc. calcítico $\mathrm{T} 7=75 \%$ calc. dolomítico $+25 \%$ gesso 
Tabela 9 - Teores de $\mathrm{Al}^{3+}\left(\mathrm{mmol}_{\mathrm{c}} \mathrm{dm}^{-3}\right)$ em 3 profundidades de solo (2a. época de amostragem - safra 1993/94).

\section{TRATAMENTO} PROFUNDIDADE (cm)

\begin{tabular}{|c|c|c|c|}
\hline & $0-20$ & $20-40$ & $40-60$ \\
\hline T1 & $7,6 A$ & $13,1 \quad A$ & $11,3 \mathrm{~A}$ \\
\hline $\mathrm{T} 2$ & $6,0 A B$ & $2,8 C$ & 7,6 $A B$ \\
\hline $\mathrm{T} 3$ & $3,5 C D$ & $7,8 \quad B$ & $6,1 \quad B$ \\
\hline $\mathrm{T} 4$ & $4,8 \quad B C$ & $6,0 \quad B C$ & $6,0 \quad B$ \\
\hline T5 & $3,6 C D$ & $5,6 C B$ & $5,3 \quad B$ \\
\hline T6 & $2,6 \quad D$ & $5,0 B C$ & $6,1 B$ \\
\hline $\mathrm{T} 7$ & $5,0 B C$ & $6,8 \quad B$ & $5,6 \quad B$ \\
\hline $\mathrm{F}$ & $20,42^{* *}$ & $23,46^{* *}$ & $8,90^{* *}$ \\
\hline $\operatorname{dms}(1 \%)$ & 2,02 & 3,5 & 3,7 \\
\hline $\mathrm{CV}(\%)$ & 19,28 & 24,13 & 24,79 \\
\hline
\end{tabular}

Médias seguidas de mesmas letras maiúsculas, na vertical, não diferem estatisticamente pelo teste de Tukey a $1 \%$.

LEGENDA

$\mathrm{T} 1=$ Testemunha

$\mathrm{T} 2=$.Calcário dolomítico

$\mathrm{T} 3=$ Calcário calcítico

$\mathrm{T} 4=$ Calcário magnesiano
$\mathrm{T} 5=50 \%$ calc. dolomítico $+50 \%$ calc. calcítico $\mathrm{T} 6=2 / 3$ calc. dolomítico $+1 / 3$ calc. calcítico $\mathrm{T} 7=75 \%$ calc. dolomítico $+25 \%$ gesso 

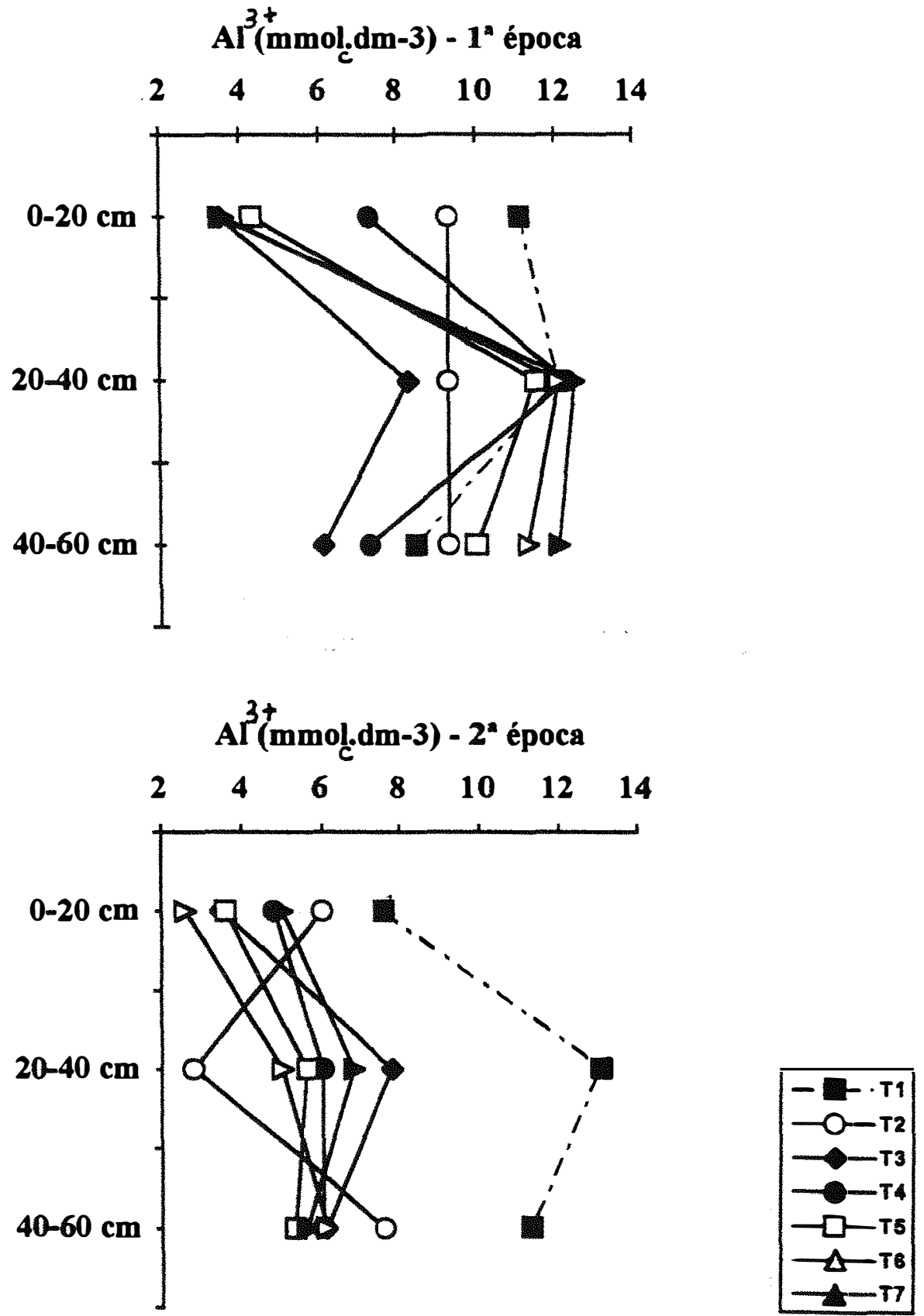

Figura 1 - Teores de $\mathrm{Al}^{3+}\left(\right.$ mmol $\left._{\mathrm{c}} \cdot \mathrm{dm}^{-3}\right)$ em 3 profundidades de solo na $1^{\mathrm{a} .}$ e $2^{\mathrm{a}}$ épocas de amostragem. 
Os teores de $\mathrm{Al}^{3+}$ na $2^{\mathrm{a} .}$ época, em geral foram menores aqueles

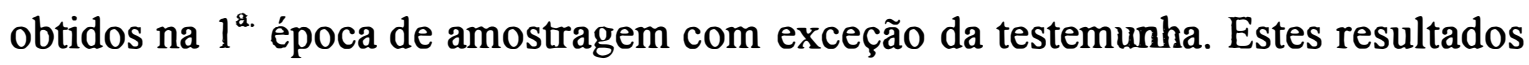
mostram a eficiência dos corretivos aplicados tanto na forma exclusiva como através de misturas de tipos de calcários ou ainda, mistura de calcário dolomítico com gesso. Estes efeitos também foram observados por MARTINS (1991), QUAGGIO et al. (1987) e SUZUKI (1989). A mistura de 2/3 de calcário dolomítico $+1 / 3$ de calcário calcítico $\left(T_{6}\right)$ promoveu a maior redução dos teores de $\mathrm{Al}^{3+}$, aos 24 meses após sua aplicação, na profundidade de $0-20 \mathrm{~cm}$. Na profundidade de 20-40 cm, foi o calcário dolomítico, aplicado na forma exclusiva. A redução dos teores de $\mathrm{Al}^{3+}$ tóxico no perfil do solo confere a planta, condições para o desenvolvimento do seu sistema radicular, explorando um maior volume de solo e consequentemente, obtendo ganhos de produtividade. Desta forma, neste trabalho foram observadas diferenças significativas entre os resultados de produção de laranja em caixas/planta e t/ha, após 24 meses da aplicação dos corretivos e gesso. O maior incremento na produtividade foi obtido na $2^{\text {a. }}$ época de colheita através da aplicação da mistura de $75 \%$ de calcário dolomítico $+25 \%$ de gesso, conforme pode ser observado nas tabelas 40 e 41 ..

As porcentagens de saturação por $\mathrm{Al}^{3+}$ no perfil do solo (tabelas 10 e 11) tiveram um comportamento e distribuição semelhantes ao dos teores de $\mathrm{Al}^{3+}$ encontrados nas 3 profundidades. Destacam-se as maiores porcentagens de saturação por $\mathrm{Al}^{3+}$ encontradas na $1^{\text {a. }}$ época e, principalmente, em subsuperfície. 
Tabela 10 - Porcentagem de saturação por aluminio (m\%) em 3 profundidades de solo (1a. época de amostragem - safra 1992/93).

\begin{tabular}{ccccccc}
\hline TRATAMENTO & \multicolumn{7}{c}{ PROFUNDIDADE (cm) } \\
\cline { 2 - 7 } & $0-20$ & $20-40$ & $40-60$ & \\
\hline T1 & 22,50 & $A B$ & 40,66 & $A$ & 45,50 & $A$ \\
T2 & 24,33 & $A$ & 39,33 & $A B$ & 32,83 & $B$ \\
T3 & 16,16 & $B$ & 28,50 & $B$ & 33,16 & $B$ \\
T4 & 17,16 & $A B$ & 39,16 & $A B$ & 38,16 & $A B$ \\
T5 & 15,50 & $B$ & 30,00 & $A B$ & 30,50 & $B$ \\
T6 & 21,00 & $A B$ & 32,66 & $A B$ & 40,16 & $A B$ \\
T7 & 14,50 & $B$ & 31,66 & $A B$ & 40,33 & $A B$ \\
F & $6,46^{* *}$ & $5,74^{* *}$ & $7,83^{* *}$ \\
dms(1\%) & 8,13 & 11,29 & 10,22 \\
CV(\%) & 19,69 & 14,82 & 12,45
\end{tabular}

Médias seguidas de mesmas letras maiúsculas, na vertical, não diferem estatisticamente pelo teste de Tukey a $1 \%$.

LEGENDA:
$\mathrm{T} 1=$ Testemunha $\mathrm{T} 5=50 \%$ calc. dolomítico $+50 \%$ calc. calcítico
$\mathrm{T} 2=$.Calcário dolomítico $\mathrm{T} 6=2 / 3$ calc. dolomítico $+1 / 3$ calc. calcítico
$\mathrm{T} 3=$ Calcário calcítico $\mathrm{T} 7=75 \%$ calc. dolomítico $+25 \%$ gesso
$\mathrm{T} 4$ = Calcário magnesiano


Tabela 11 - Porcentagem de saturação por alumínio (m\%) em 3 profundidades de solo (2a. época de amostragem - safra 1993/94).

\begin{tabular}{|c|c|c|c|c|c|c|}
\hline \multirow{3}{*}{$\begin{array}{c}\text { TRATAMENTO } \\
\\
\text { T1 }\end{array}$} & \multicolumn{6}{|c|}{ PROFUNDIDADE $(\mathrm{cm})$} \\
\hline & \multicolumn{2}{|c|}{$0-20$} & \multicolumn{2}{|c|}{$20-40$} & \multicolumn{2}{|c|}{$40-60$} \\
\hline & 7.83 & $A B$ & 13,83 & $\mathrm{C}$ & 21,16 & $A B$ \\
\hline $\mathrm{T} 2$ & 9.16 & $A$ & 23,33 & $A B$ & 17,33 & $B C$ \\
\hline T3 & 9.33 & $A$ & 24,66 & $A$ & 12,83 & C \\
\hline $\mathrm{T} 4$ & 8.16 & $A B$ & 16,16 & $B C$ & 14,50 & $B C$ \\
\hline T5 & 6.50 & $A B$ & 21,66 & $A B$ & 15,16 & $B C$ \\
\hline T6 & 5.33 & B & 21,50 & $A B$ & 26,83 & A \\
\hline $\mathrm{T} 7$ & 7.16 & $A B$ & 19,50 & $A B C$ & 19,66 & $B C$ \\
\hline $\mathrm{F}$ & 5,26 & 6** & & $8^{* *}$ & 13,97 & \\
\hline $\mathrm{dms}(1 \%)$ & 3,3 & & 7,3 & & 6,9 & \\
\hline $\mathrm{CV}(\%)$ & 20,0 & & 16 , & & 17,2 & \\
\hline
\end{tabular}

Médias seguidas de mesmas letras maiúsculas, na vertical, não diferem estatisticamente pelo teste de Tukey a $1 \%$.

\section{LEGENDA}
$\mathrm{T} 1=$ Testemunha $\mathrm{T} 5=50 \%$ calc. dolomítico $+50 \%$ calc. calcítico
$\mathrm{T} 2$ = Calcário dolomítico $\mathrm{T} 6=2 / 3$ calc. dolomítico $+1 / 3$ calc. calcítico
$\mathrm{T} 3$ = Calcário calcítico $\mathrm{T} 7=75 \%$ calc. dolomítico $+25 \%$ gesso
T4 = Calcário magnesiano


A redução da porcentagem de saturação por $\mathrm{Al}^{3+}$ na camada arável $(0-20 \mathrm{~cm})$ verificada entre 12 e 24 meses, após a aplicação dos tratamentos (tabelas 14 e 15), esteve associada aos aumentos dos teores de cálcio, especialmente nos tratamentos $T_{3}$ e $T_{5}$, na $1^{\text {a. }}$ época e $T_{7}$ na $2^{\text {a. época de }}$ amostragem.

O calcário calcítico $\left(\mathrm{T}_{3}\right)$ e as misturas de calcário dolomítico + calcário calcítico $\left(\mathrm{T}_{5}\right.$ e $\left.\mathrm{T}_{6}\right)$ e calcário dolomítico + gesso $\left(\mathrm{T}_{7}\right)$ foram os tratamentos que reduziram significativamente as porcentagens de saturação por $\mathrm{Al}^{3+}$, em relação a testemunha $\left(T_{1}\right)$, na profundidade de $0-20 \mathrm{~cm}$, aos 12 meses.

Os dados da tabela 10 permitem observar a baixa eficiência dos corretivos e do gesso nas doses adotadas em reduzir os teores de $\mathrm{Al}^{3+}$ tóxicos do solo em subsuperfície até 12 meses após a sua aplicação. O nível de eficácia destes produtos aumentou significativamente entre 12 e 24 meses após a sua aplicação (tabela 11).

Os teores de $\mathrm{H}^{+}+\mathrm{Al}^{3+}$ obtidos nas 2 épocas de amostragens de solo não diferiram estatisticamente em relação aos tratamentos aplicados, em nenhuma das profundidades avaliadas (tabelas 12 e 13). Também os valores de pH não diferiram significativamente em nenhuma profundidade das 2 épocas.

Por outro lado, os teores de $\mathrm{Al}^{3+}$ diferiram em todas as profundidades, nas 2 épocas, sendo que as parcelas testemunhas apresentaram os maiores teores. Sugere-se que a não variação significativa do $\mathrm{pH}$ se deva ao 
Tabela 12 - Teores de $\mathrm{H}^{+}+\mathrm{Al}^{3+}\left(\mathrm{mmol}_{\mathrm{c}} \cdot \mathrm{dm}^{-3}\right)$ em 3 profundidades de solo (1a. época de amostragem - safra 1992/93).

\begin{tabular}{cccc}
\hline TRATAMENTO & \multicolumn{3}{c}{ PROFUNDIDADE (cm) } \\
\cline { 2 - 4 } & $0-20$ & $20-40$ & $40-60$ \\
\hline T1 & 76,3 & 76,9 & 73,0 \\
T3 & 72,6 & 79,3 & 71,0 \\
T4 & 61,3 & 76,5 & 65,6 \\
T5 & 59,8 & 70,8 & 63,0 \\
T6 & 58,0 & 72,3 & 64,6 \\
T7 & 65,3 & 75,1 & 74,0 \\
F & 65,0 & 63,5 & 66,6 \\
dms(5\%) & $0,89 \mathrm{NS}$ & $0,48 \mathrm{NS}$ & $0,90 \mathrm{NS}$ \\
CV(\%) & 23,00 & 27,00 & 20,60 \\
\hline
\end{tabular}

\section{LEGENDA}

$\mathrm{T} 1=$ Testemunha

$\mathrm{T} 2$ = . Calcário dolomítico

$\mathrm{T} 3$ = Calcário calcítico

T4= Calcário magnesiano
$\mathrm{T} 5=50 \%$ calc. dolomítico $+50 \%$ calc. calcítico

$\mathrm{T} 6=2 / 3$ calc. dolomítico $+1 / 3$ calc. calcítico

$\mathrm{T} 7=75 \%$ calc. dolomítico $+25 \%$ gesso 
Tabela 13 - Teores de $\mathrm{H}^{+}+\mathrm{Al}^{3+}\left(\right.$ mmol $_{\mathrm{c}} \cdot \mathrm{dm}^{-3}$ ) em 3 profundidades de solo (2a. época de amostragem - safra 1993/94).

\begin{tabular}{cccc}
\hline TRATAMENTO & \multicolumn{3}{c}{ PROFUNDIDADE (cm) } \\
\cline { 2 - 4 } & $0-20$ & $20-40$ & $40-60$ \\
T1 & 75,5 & 77,6 & 77,2 \\
T2 & 58,0 & 63,3 & 66,3 \\
T3 & 56,3 & 69,6 & 64,0 \\
T5 & 62,0 & 75,1 & 67,3 \\
T6 & 67,1 & 75,6 & 67,1 \\
T7 & 70,8 & 71,6 & 76,0 \\
F & 64,1 & 67,6 & 66,0 \\
dms(5\%) & $0,85 \mathrm{NS}$ & $1,29 \mathrm{NS}$ & $1,41 \mathrm{NS}$ \\
CV(\%) & 22,70 & 22,50 & 19,60 \\
\hline
\end{tabular}

\section{LEGENDA}

$\mathrm{T} 1=$ Testemunha

$\mathrm{T} 2=$. Calcário dolomítico

$\mathrm{T} 3=$ Calcário calcítico

T4= Calcário magnesiano
$\mathrm{T} 5=50 \%$ calc. dolomítico $+50 \%$ calc. calcítico

$\mathrm{T} 6=2 / 3$ calc. dolomítico $+1 / 3$ calc. calcítico

$\mathrm{T} 7=75 \%$ calc. dolomítico $+25 \%$ gesso 
seguinte: Se por um lado, a calagem eleva o $\mathrm{pH}$ do solo, por outro, as adubações nitrogenadas e as aplicações de S elementar acidificam o solo. Desta forma, é de se esperar que não ocorram variações significativas do $\mathrm{pH}$. Além disso, convém lembrar a importância do poder tampão deste tipo de solo.

\subsection{2. $\mathrm{Ca}^{2+}, \mathrm{Mg}^{2+} \mathrm{e} \mathrm{K}^{+}$trocáveis e $\mathrm{S}-\mathrm{SO}_{4}{ }^{2-}$}

Nas tabelas 14 e 15 são apresentados os teores de $\mathrm{Ca}^{2+}$ encontrados nas amostras de solo coletadas em 3 profundidades e em 2 épocas de amostragens.

Os teores de $\mathrm{Ca}^{2+}$ diferiram significativamente em todas as 3 profundidades, na $1^{\mathrm{a}}$ época de amostragem. A mistura de $50 \%$ de calcário dolomítico $+50 \%$ de calcário calcítico $\left(\mathrm{T}_{5}\right)$ e o calcário calcítico exclusivo $\left(\mathrm{T}_{3}\right)$ foram os tratamentos que apresentaram os maiores teores de $\mathrm{Ca}^{2+}$ na profundidade de 0-20 cm aos 12 meses após sua aplicação. Resultados semelhantes também foram obtidos por RITCHEY et al., (1981) e MARTINS (1991), sendo observado acréscimos dos teores de $\mathrm{Ca}^{2+} \mathrm{e} \mathrm{Mg}^{2+}$ até a profundidade de $60 \mathrm{~cm}$. Nesse sentido, LOPES (1983) e QUAGGIO et al. (1987) observaram em seus trabalhos que após a aplicação da calagem, a lixiviação de bases trocáveis ocorreu num processo

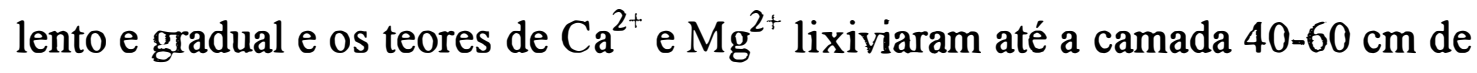


Tabela 14 - Teores de $\mathrm{Ca}^{2+}\left(\mathrm{mmol}_{\mathrm{c}} \cdot \mathrm{dm}^{-3}\right)$ em 3 profundidades de solo (1a. época de amostragem - safra 1992/93).

\begin{tabular}{cccc}
\hline TRATAMENTO & \multicolumn{3}{c}{ PROFUNDIDADE $(\mathrm{cm})$} \\
\cline { 2 - 4 } & $0-20$ & $20-40$ & $40-60$ \\
\hline T1 & $17,1 E$ & $17,3 \mathrm{C}$ & $13,6 \mathrm{D}$ \\
$\mathrm{T} 2$ & $25,1 \mathrm{DE}$ & $20,3 \mathrm{C}$ & $23,5 \mathrm{BC}$ \\
$\mathrm{T} 3$ & $48,8 \mathrm{~A}$ & $23,8 \mathrm{BC}$ & $32,3 \mathrm{~B}$ \\
$\mathrm{~T} 4$ & $28,3 \mathrm{CD}$ & $32,1 \mathrm{AB}$ & $24,8 \mathrm{BC}$ \\
$\mathrm{T} 5$ & $51,3 \mathrm{~A}$ & $36,6 \mathrm{~A}$ & $44,0 \mathrm{~A}$ \\
$\mathrm{~T} 6$ & $38,5 \mathrm{~B}$ & $16,0 \mathrm{C}$ & $19,0 \mathrm{CD}$ \\
$\mathrm{T} 7$ & $35,8 \mathrm{BC}$ & $16,8 \mathrm{C}$ & $24,0 \mathrm{BC}$ \\
$\mathrm{F}$ & $54,51^{* *}$ & $16,42^{* *}$ & $29,09^{* *}$ \\
$\mathrm{dms}(1 \%)$ & 9,10 & 10,80 & 9,80 \\
$\mathrm{CV}(\%)$ & 11,79 & 21,09 & 17,18
\end{tabular}

Médias seguidas de mesmas letras maiúsculas, na vertical, não diferem estatisticamente pelo teste de Tukey a $1 \%$.

\section{LEGENDA}

$$
\begin{array}{ll}
\mathrm{T} 1=\text { Testemunha } & \mathrm{T} 5=50 \% \text { calc. dolomítico }+50 \% \text { calc. calcítico } \\
\mathrm{T} 2=\text {. Calcário dolomítico } & \mathrm{T} 6=2 / 3 \text { calc. dolomítico }+1 / 3 \text { calc. calcítico } \\
\mathrm{T} 3=\text { Calcário calcítico } & \mathrm{T} 7=75 \% \text { calc. dolomítico }+25 \% \text { gesso } \\
\mathrm{T} 4=\text { Calcário magnesiano } &
\end{array}
$$


Tabela 15 - Teores de $\mathrm{Ca}^{2+}\left(\mathrm{mmol}_{\mathrm{c}} \cdot \mathrm{dm}^{-3}\right)$ em 3 profundidades de solo na (2a. época de amostragem - safra 1993/94).

\begin{tabular}{cccc}
\hline TRATAMENTO & \multicolumn{3}{c}{ PROFUNDIDADE (cm) } \\
\cline { 2 - 4 } & $0-20$ & $20-40$ & $40-60$ \\
\hline T1 & $21,1 b$ & 15,6 & $11,3 b$ \\
T2 & $27,3 a b$ & 16,5 & $13,6 a b$ \\
T3 & $25,6 a b$ & 16,8 & $13,0 a b$ \\
T4 & $24,0 a b$ & 15,8 & $15,6 a$ \\
T5 & $24,6 a b$ & 16,3 & $14,1 a b$ \\
T6 & $26,3 a b$ & 16,3 & $13,8 a b$ \\
T7 & $30,8 a$ & 17,5 & $14,1 a b$ \\
\hline F & $2,15^{* *}$ & $0,36 \mathrm{NS}$ & $2,27^{*}$ \\
dms(5\%) & 9,10 & 4,50 & 3,80 \\
CV(\%) & 19,47 & 15,21 & 15,62
\end{tabular}

Médias seguidas de mesmas letras minúsculas, na vertical, não diferem estatisticamente pelo teste de Tukey a $5 \%$.

\section{LEGENDA}

$\mathrm{T} 1=$ Testemunha

$\mathrm{T} 2=$.Calcário dolomítico

$\mathrm{T} 3=$ Calcário calcítico

$\mathrm{T} 4=$ Calcário magnesiano
$\mathrm{T} 5=50 \%$ calc. dolomítico $+50 \%$ calc. calcítico

$\mathrm{T} 6=2 / 3$ calc. dolomítico $+1 / 3$ calc. calcítico

$\mathrm{T} 7=75 \%$ calc . dolomítico $+25 \%$ gesso 
profundidade, logo aos 6 meses, após aplicação dos corretivos, havendo inclusive pequenas alterações nos valores de $\mathrm{pH}$.

$\mathrm{Na}$ figura 2, estão representados os teores de $\mathrm{Ca}^{2+}$ nas 3 profundidades para cada época de amostragem. $\mathrm{Na} 1^{\mathrm{a}}$ época, a testemunha apresentou os menores teores de $\mathrm{Ca}^{2+}$, dentre todos os tratamentos aplicados. Verificou-se a tendência dos teores de $\mathrm{Ca}^{2+}$ decrescerem em função do aumento da profundidade, principalmente na $2^{\mathrm{a}}$ época.

Os teores médios de $\mathrm{Ca}^{2+}$ obtidos na $2^{\mathrm{a} .}$ época, em geral foram menores aos obtidos na $1^{\mathrm{a} \cdot}$ época. Alterou-se a escala dos teores de $\mathrm{Ca}^{2+}$ na $2^{\mathrm{a} .}$ época (figura 2), com a finalidade de se diminuir a superposição das retas representativas de cada tratamento. Desta forma, foi possível evidenciar os decréscimos dos teores de $\mathrm{Ca}^{2+}$ em subsuperfície. A mistura de $75 \%$ de calcário dolomítico $+25 \%$ de gesso $\left(\mathrm{T}_{7}\right)$ apresentou os maiores teores de $\mathrm{Ca}^{2+}$ na profundidade de $0-20 \mathrm{~cm}$ ( $2^{\mathrm{a}}$ época), diferindo significativamente da testemunha. Em todos os demais tratamentos da $2^{\mathrm{a} .}$ época, os teores de $\mathrm{Ca}^{2+}$ diminuiram com o aumento da profundidade. A distribuição do $\mathrm{Ca}^{2+}$ foi também estudada em diversas profundidades por RITCHEY et al. (1981) e observaram as mesmas

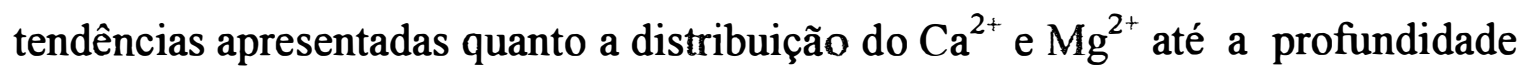
de 60-75 cm. Estes autores relataram, inclusive, a tendência do $\mathrm{SO}_{4}{ }^{2-}$ adicionado ao solo pelo gesso, em acelerar a movimentação de $\mathrm{Ca}^{2+}$ e outros cátions para camadas mais profundas, reduzindo as limitações de natureza química do solo, as 

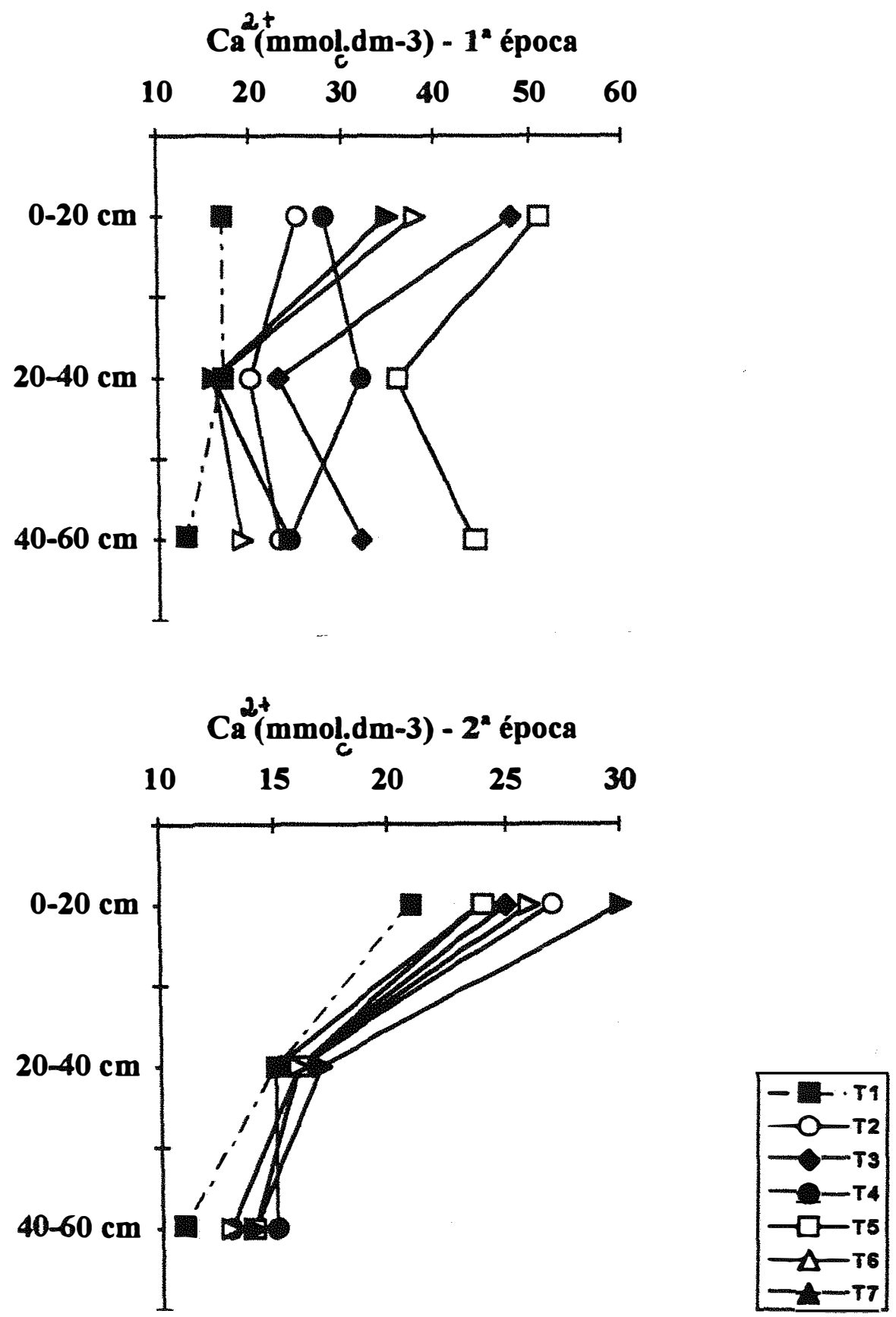

Figura 2 - Teores de $\mathrm{Ca}^{2+}\left(\mathrm{mmol}_{c} \cdot \mathrm{dm}^{-3}\right)$ em 3 profundidades de solo na $1^{\mathrm{a} .}$ e $2^{\mathrm{a}}$ épocas de amostragem. 
quais impedem o enraizamento profundo das plantas.

Os teores de $\mathrm{Mg}^{2+}$ encontrados nas amostras de solo estão

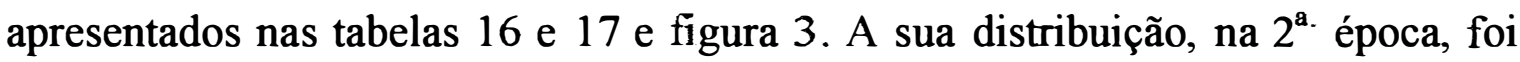
semelhante a do $\mathrm{Ca}^{2+}$, (teores menores e decrescentes no perfil).

$\mathrm{Na} 1^{\mathrm{a}}$ época, os maiores teores de $\mathrm{Mg}^{2+}$ foram encontrados nas amostras que receberam aplicação dos tratamentos $T_{5}$ e $T_{7}$, respectivamente, às misturas de $50 \%$ de calcário dolomítico $+50 \%$ de calcário calcítico e, $75 \%$ de calcário dolomítico $+25 \%$ de gesso, nas 3 profundidades.

$\mathrm{Na} 2^{\mathrm{a}}$ época, na profundidade de $0-20 \mathrm{~cm}$, os teores de $\mathrm{Mg}^{2+}$ obtidos com a aplicação da mistura calcário dolomítico + gesso diferiram significativamente dos obtidos para a testemunha (tabela 17). Não houve diferenças significativas entre os teores de $\mathrm{Mg}^{2+}$ obtidos para nenhum dos tratamentos em subsuperficie $(20$ a $60 \mathrm{~cm})$.

A análise da distribuição do $\mathrm{Mg}^{2+}$ apresentada na figura $3-2^{\mathrm{a} .}$ época permite sugerir uma possível lixiviação deste nutriente no solo. Provavelmente, as adições de $\mathrm{Ca}^{2+}$ através da calagem e, as adições de $\mathrm{K}^{+}$através das adubações, tenham acelerado a velocidade de lixiviação do $\mathrm{Mg}^{2+}$. Este fato se deve à a competitividade iônica que ocorre durante o processo de absorção iônica

A tendência dos teores de $\mathrm{Mg}^{2+}$ diminuírem com o aumento da profundidade tem sido constatada por diversos pesquisadores, dentre eles, MAZZA (1993), observou a redução dos teores de $\mathrm{Mg}^{2+}$ nas profundidades de 
Tabela 16 - Teores de $\mathrm{Mg}^{2+}\left(\mathrm{mmol}_{\mathrm{c} .} \cdot \mathrm{dm}^{-3}\right)$ em 3 profundidades de solo (1a. época de amostragem - safra 1992/93).

\begin{tabular}{cccc}
\hline TRATAMENTO & \multicolumn{3}{c}{ PROFUNDIDADE (cm) } \\
\cline { 2 - 4 } & $0-20$ & $20-40$ & $40-60$ \\
\hline T1 & $6,8 C$ & $7,8 A B$ & $6,6 B$ \\
T3 & $10,1 B C$ & $6,8 A B$ & $6,8 B$ \\
T4 & $8,3 C$ & $6,0 B$ & $6,6 B$ \\
T5 & $10,1 B C$ & $6,5 B$ & $7,8 B$ \\
T6 & $15,6 A B$ & $10,6 A$ & $13,6 A$ \\
T7 & $17,0 A$ & $6,5 B$ & $6,6 B$ \\
F & $15,5 A B$ & $7,1 A B$ & $8,8 B$ \\
dms(1\%) & $12,74^{* *}$ & $4,42^{* *}$ & $22,08^{* *}$ \\
CV(\%) & 6,00 & 4,00 & 2,90 \\
\hline
\end{tabular}

Médias seguidas de mesmas letras maiúsculas, na vertical, não diferem estatisticamente pelo teste de Tukey a $1 \%$.

\section{LEGENDA}

$\mathrm{T} 1=$ Testemunha

$\mathrm{T} 2=$.Calcário dolomítico

$\mathrm{T} 3=$ Calcário calcítico

T4= Calcário magnesiano
$\mathrm{T} 5=50 \%$ calc. dolomítico $+50 \%$ calc. calcítico $\mathrm{T} 6=2 / 3$ calc. dolomítico $+1 / 3$ calc. calcítico

$\mathrm{T} 7=75 \%$ calc. dolomítico $+25 \%$ gesso 
Tabela 17 - Teores de $\mathrm{Mg}^{2+}\left(\mathrm{mmol}_{\mathrm{c}} \cdot \mathrm{dm}^{-3}\right)$ em 3 profundidades de solo (2a. época de amostragem - safra 1993/94).

\begin{tabular}{cccc}
\hline TRATAMENTO & \multicolumn{3}{c}{ PROFUNDIDADE (cm) } \\
\cline { 2 - 4 } & $0-20$ & $20-40$ & $40-60$ \\
\hline T1 & $6,0 B$ & 7,5 & 3,6 \\
T2 & $8,8 A B$ & 5,8 & 4,3 \\
T3 & $8,0 B$ & 5,6 & 4,6 \\
T4 & $8,5 A B$ & 6,0 & 4,8 \\
T5 & $8,0 B$ & 5,6 & 4,8 \\
T6 & $9,0 A B$ & 7,0 & 4,5 \\
T7 & $11,8 A$ & 6,8 & 5,3 \\
\hline F & $7,15^{* *}$ & $2,94 N S$ & $1,29 \mathrm{NS}$ \\
dms(1\%) & 3,50 & 2,30 & 2,40 \\
CV(\%) & 18,54 & 16,65 & 24,24 \\
\hline
\end{tabular}

Médias seguidas de mesmas letras maiúsculas, na vertical, não diferem estatisticamente pelo teste de Tukey a $1 \%$.

\section{LEGENDA}

$$
\begin{array}{ll}
\mathrm{T} 1=\text { Testemunha } & \mathrm{T} 5=50 \% \text { calc. dolomítico }+50 \% \text { calc. calcítico } \\
\mathrm{T} 2=\text {. Calcário dolomítico } & \mathrm{T} 6=2 / 3 \text { calc. dolomítico }+1 / 3 \text { calc. calcítico } \\
\mathrm{T} 3=\text { Calcário calcítico } & \mathrm{T} 7=75 \% \text { calc. dolomitico }+25 \% \text { gesso } \\
\mathrm{T} 4=\text { Calcário magnesiano } &
\end{array}
$$



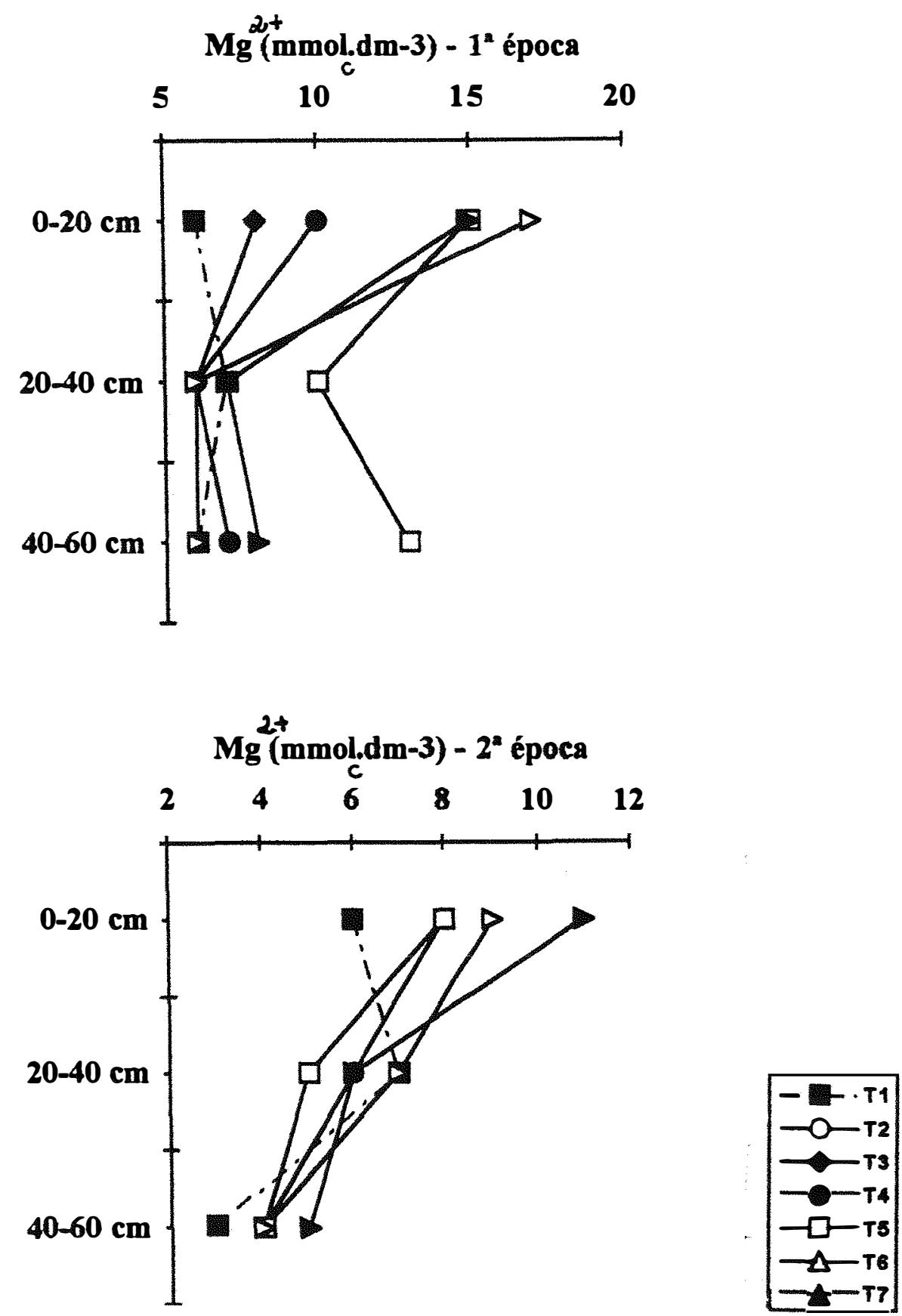

Figura 3 - Teores de $\mathrm{Mg}^{2+}\left(\mathrm{mmol}_{c} \cdot \mathrm{dm}^{-3}\right)$ em 3 profundidades de solo na $1^{\mathrm{a}}$ e $2^{\mathrm{a}}$ épocas de amostragem. 
pelas raízes.

20-40 cm e 40-60 cm, aos 30 meses após aplicação de doses e combinações de calcário e gesso. Recentemente, ROLIM (1995), observou decréscimos dos teores de $\mathrm{Mg}^{2+}$ no perfil do solo até a profundidade de $100 \mathrm{~cm}$, principalmente nos tratamentos em que foram aplicados a magnesita exclusiva e a mistura de magnesita com gesso. Os teores de $\mathrm{Mg}^{2+}$ encontrados na profundidade de 75-100 cm aos 40 meses após a aplicação desses tratamentos, foram baixos e semelhantes aos teores encontrados na profundidade $0-20 \mathrm{~cm}$, na parcela testemunha, por ocasião da instalação do experimento.

Nas tabelas 18 e 19 estão os teores de $\mathrm{K}^{+}$determinados nas amostras de solo coletados em 3 profundidades, respectivamente, na $1^{\text {a. }}$ e $2^{\text {a. }}$ épocas de amostragem. Estes teores foram plotados em gráficos (figura 4) com a finalidade de destacar os efeitos de alguns tratamentos.

$\mathrm{Na} 1^{\mathrm{a}}$ época de avaliação, os teores de $\mathrm{K}^{+}$diferiram significativamente apenas nas profundidades de $20-40 \mathrm{~cm}$ e $40-60 \mathrm{~cm}$, basicamente entre os tratamentos $T_{5}$ e $T_{7}$. As parcelas que receberam aplicação de calcário dolomítico + gesso, apresentaram os menores teores de $\mathrm{K}^{+}$em todas as profundidades. Os maiores teores de $\mathrm{K}^{+}$foram encontrados na camada arável do solo $(0-20 \mathrm{~cm})$, e não houve diferença significativa entre nenhum dos tratamentos aplicados. Na figura 4 ( $1^{\text {a. }}$ época) observa-se que o tratamento $T_{7}$ (mistura de calcário dolomítico + gesso) promoveu uma considerável redução do teor de $\mathrm{K}^{+}$ 
Tabela 18 - Teores de $\mathrm{K}^{+}\left(\mathrm{mmol}_{\mathrm{c}} \cdot \mathrm{dm}^{-3}\right)$ em 3 profundidades de solo (1a. época de amostragem - safra 1992/93).

\begin{tabular}{cccc}
\hline TRATAMENTO & \multicolumn{3}{c}{ PROFUNDIDADE $(\mathrm{cm})$} \\
\cline { 2 - 4 } & $0-20$ & $20-40$ & $40-60$ \\
T1 & 2,8 & $1,9 a b$ & $1,8 A B C$ \\
T3 & 2,7 & $2,1 a b$ & $1,4 \mathrm{CD}$ \\
T4 & 2,9 & $1,9 a b$ & $1,7 \mathrm{BCD}$ \\
T5 & 2,7 & $1,9 a b$ & $1,8 \mathrm{ABC}$ \\
T6 & 3,5 & $2,3 a$ & $2,2 \mathrm{~A}$ \\
T7 & 3,2 & $2,0 a b$ & $1,9 A B$ \\
F & 2,7 & $1,4 b$ & $1,3 \mathrm{D}$ \\
dms(5\%) & $2,01 \mathrm{NS}$ & $2,32^{*}$ & $13,37^{* *}$ \\
dms(1\%) & 0,90 & 0,80 & 0,30 \\
CV(\%) & 1,10 & 1,00 & 0,40 \\
\hline
\end{tabular}

Médias seguidas de mesmas letras minúsculas ou maiúsculas, na vertical, não diferem estatisticamente pelo teste de Tukey a $5 \%$ e $1 \%$, respectivamente.

\section{LEGENDA}

$\mathrm{T} 1=$ Testemunha $\quad \mathrm{T} 5=50 \%$ calc. dolomítico $+50 \%$ calc. calcítico

$\mathrm{T} 2=$. Calcário dolomítico $\quad \mathrm{T} 6=2 / 3$ calc. dolomítico $+1 / 3$ calc. calcítico

$\mathrm{T} 3=$ Calcário calcítico $\quad \mathrm{T} 7=75 \%$ calc. dolomítico $+25 \%$ gesso

$\mathrm{T} 4=$ Calcário magnesiano 
Tabela 19 - Teores de $\mathrm{K}^{+}\left(\right.$mmol $\left._{\mathrm{c}} \cdot \mathrm{dm}^{-3}\right)$ em 3 profundidades de solo (2a. época de amostragem - safra 1993/94).

\begin{tabular}{cccc}
\hline TRATAMENTO & \multicolumn{3}{c}{ PROFUNDIDADE $(\mathrm{cm})$} \\
\cline { 2 - 4 } & $0-20$ & $20-40$ & $40-60$ \\
\hline T1 & $2,6 A B$ & $2,0 B C$ & $1,2 B$ \\
T3 & $2,4 A B$ & $2,9 A$ & $2,2 A$ \\
T4 & $2,2 B$ & $1,5 C$ & $1,3 B$ \\
T5 & $3,1 A$ & $1,8 B C$ & $1,7 A B$ \\
T6 & $2,8 A B$ & $2,1 A B C$ & $1,6 A B$ \\
T7 & $2,9 A B$ & $2,1 A B C$ & $1,3 B$ \\
F & $3,2 A$ & $2,3 A B$ & $1,5 A B$ \\
dms(1\%) & $4,30^{* *}$ & $8,17^{* *}$ & $6,59^{* *}$ \\
CV(\%) & 0,90 & 0,70 & 0,60 \\
\hline
\end{tabular}

Médias seguidas de mesmas letras maiúsculas, na vertical, não diferem estatisticamente pelo teste de Tukey a $1 \%$.

\section{LEGENDA}

$\mathrm{T} 1=$ Testemunha

$\mathrm{T} 2=$.Calcário dolomítico

$\mathrm{T} 3=$ Calcário calcítico

T4= Calcário magnesiano
$\mathrm{T} 5=50 \%$ calc. dolomítico $+50 \%$ calc. calcítico

$\mathrm{T} 6=2 / 3$ calc. dolomítico $+1 / 3$ calc. calcítico

$\mathrm{T} 7=75 \%$ calc dolomítico $+25 \%$ gesso 
até a profundidade de $60 \mathrm{~cm}$. Este efeito também foi observado por QUAGGIO et al. (1982), tendo responsabilizado o gesso pelo deslocamento tanto do $\mathrm{K}^{+}$como do $\mathrm{Mg}^{2+}$ da camada arável para a subsuperfície.

Após 24 meses da aplicação dos tratamentos, os teores de $\mathrm{K}^{+}$ diferiram significativamente, nas 3 profundidades estudadas. A figura $4-2^{\mathrm{a}}$ época, evidencia os decréscimos dos teores de $\mathrm{K}^{+}$, até a profundidade de $60 \mathrm{~cm}$. Apenas o tratamento $T_{2}$ (calcário dolomítico exclusivo) apresentou uma distribuição no perfil do solo, contrária aos demais tratamentos, ou seja, os teores de $\mathrm{K}^{+}$aumentaram até a profundidade de $40 \mathrm{~cm}$ e depois decresceram até a profundidade de $60 \mathrm{~cm}$. É dificil explicar a causa deste comportamento, sabendose que o $\mathrm{K}^{+}$foi adicionado ao solo como $\mathrm{KCl}$, integrante da adubação básica e distribuída uniformemente em todas parcelas.

Esperava-se inicialmente, que os teores de $\mathrm{K}^{+}$nas amostras coletadas nas parcelas testemunhas fossem superiores aos teores obtidos nas parcelas tratados com calcário e gesso, tendo em vista a elevada capacidade de deslocamento de $\mathrm{Mg}^{2+}$ e de $\mathrm{K}^{+}$que estes produtos promovem no solo. Provavelmente, as dosagens de calcário e gesso aplicadas não tenham sido suficientes para se observar este efeito. Entretanto, CARVALHO (1994), estudou os efeitos do sulfato de cálcio, fosfogesso e carbonato de cálcio em vasos cultivados com milho e observou que os teores de $\mathrm{K}^{+}$trocável foram significativamente superiores nas amostras de solo sem tratamento (testemunha). 

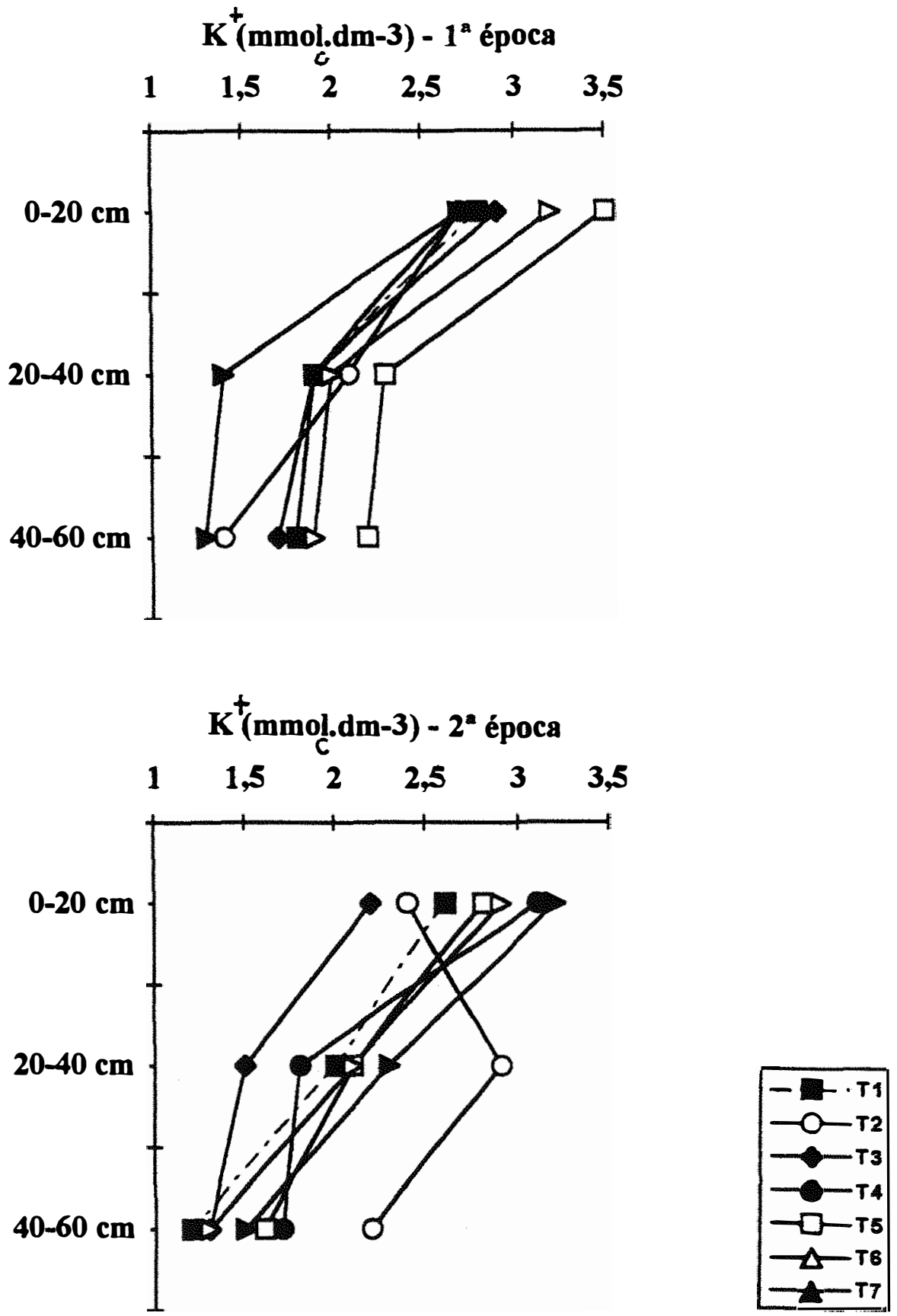

Figura 4 - Teores de $\mathrm{K}^{+}\left(\mathrm{mmol}_{\mathrm{c}} \cdot \mathrm{dm}^{-3}\right)$ em 3 profundidades de solo na $1^{\mathrm{a} .}$ e $2^{\mathrm{a}}$ épocas de amostragem. 
Os teores de $\mathrm{SO}_{4}{ }^{2-}$ obtidos nas amostras analisadas podem ser vistos nas tabelas 20 e 21 e, na figura 5. Esses resultados evidenciam a ação eficiente do gesso principalmente, em subsuperfície.

Após 12 meses da aplicação dos tratamentos, ( $1^{\mathrm{a}}$ época $)$ os teores de $\mathrm{SO}_{4}{ }^{2-}$, não diferiram entre $\mathrm{si}$, em nenhuma das profundidades, mas entre as profundidades, as diferenças foram acentuadas principalmente em subsuperficie $(20-60 \mathrm{~cm})$.

Após 24 meses da aplicação dos tratamentos ( $2^{\mathrm{a} .}$ época), observa-se que os teores de $\mathrm{SO}_{4}{ }^{2-}$ encontrados em todas as profundidades foram menores do que os obtidos na $1^{\text {a. }}$ avaliação. Alguns tratamentos diferiram significativamente a $1 \%$ de probabilidade, nas profundidades de $20-40 \mathrm{~cm}$ e $40-60 \mathrm{~cm}$ (tabela 21 ). A mistura de $75 \%$ de calcário dolomítico $+25 \%$ de gesso $\left(\mathrm{T}_{7}\right)$ foi o tratamento mais eficiente na profundidade de $40-60 \mathrm{~cm}$. Os teores de $\mathrm{SO}_{4}{ }^{2-}$ encontrados no perfil do solo, nas 3 profundidades das 2 épocas estão apresentados na figura 5. Os significativos encrementos ocorridos em subsuperfície, na $2^{\text {a. }}$ época, foram evidenciados. Não se esperava a ocorrência de elevados teores de $\mathrm{S}_{-} \mathrm{SO}_{4}{ }^{2-}$ nas parcelas testemunhas $\left(T_{1}\right)$ nas 2 épocas de amostragem. Se considerarmos que durante a experimentação, a fonte de fósforo utilizada na adubação básica (formulada pela firma Solorrico S/A) foi o superfosfato triplo, sugere-se que os teores elevados de $\mathrm{SO}_{4}{ }^{2-}$ encontrados nas amostras das parcelas testemunhas, tenham sua origem nos adubos fosfatados, portadores de enxofre, aplicados na 
Tabela 20 - Teores de $\mathrm{S}-\mathrm{SO}_{4}{ }^{2-}\left(\mathrm{mg} \cdot \mathrm{dm}^{-3}\right)$ em 3 profundidades de solo (1a. época de amostragem - safra 1992/93).

\begin{tabular}{cccc}
\hline TRATAMENTO & \multicolumn{3}{c}{ PROFUNDIDADE (cm) } \\
\cline { 2 - 4 } & $0-20$ & $20-40$ & $40-60$ \\
\hline T1 & 53 & 84 & 87 \\
T3 & 61 & 76 & 87 \\
T4 & 56 & 82 & 83 \\
T5 & 62 & 87 & 90 \\
T6 & 54 & 89 & 91 \\
T7 & 54 & 94 & 97 \\
\hline F & 62 & 91 & 90 \\
dms(5\%) & 1,43 NS & $1,06 \mathrm{NS}$ & $0,46 \mathrm{NS}$ \\
CV(\%) & 15,67 & 26,25 & 27,37 \\
\hline
\end{tabular}

\section{LEGENDA}

$\mathrm{T} 1=$ Testemunha

$\mathrm{T} 2=$.Calcário dolomítico

$\mathrm{T} 3$ = Calcário calcítico

T4 = Calcário magnesiano
$\mathrm{T} 5=50 \%$ calc. dolomítico $+50 \%$ calc. calcítico

$\mathrm{T} 6=2 / 3$ calc. dolomítico $+1 / 3$ calc. calcítico

$\mathrm{T} 7=75 \%$ calc. dolomítico $+25 \%$ gesso 
Tabela $21-$ Teores de $\mathrm{S}-\mathrm{SO}_{4}{ }^{2-}\left(\mathrm{mg} \cdot \mathrm{dm}^{-3}\right)$ em 3 profundidades de solo (2a. época de amostragem - safra 1993/94). PROFUNDIDADE (cm)

\begin{tabular}{cccc}
\cline { 2 - 3 } & $0-20$ & $20-40$ & $40-60$ \\
\hline T1 & 19 & $20 B$ & $33 B$ \\
T3 & 20 & $27 A B$ & $45 A B$ \\
T4 & 23 & $22 B$ & $41 B$ \\
T5 & 20 & $26 A B$ & $39 B$ \\
T6 & 19 & $23 A B$ & $31 B$ \\
T7 & 21 & $23 A B$ & $33 B$ \\
F & 25 & $33 A$ & $57 A$ \\
dms(1\%) & $2,16 \mathrm{NS}$ & $5,19^{* *}$ & $10,07^{* *}$ \\
CV(\%) & 7,83 & 9,69 & 15,65 \\
\hline
\end{tabular}

Médias seguidas de mesmas letras maiúsculas, na vertical, não diferem estatisticamente pelo teste de Tukey a $1 \%$.

LEGENDA

$\mathrm{T} 1=$ Testemunha

$\mathrm{T} 2=$. Calcário dolomítico

$\mathrm{T} 3$ = Calcário calcítico

$\mathrm{T} 4=$ Calcário magnesiano
$\mathrm{T} 5=50 \%$ calc. dolomítico $+50 \%$ calc. calcítico $\mathrm{T} 6=2 / 3$ calc. dolomítico $+1 / 3$ calc. calcítico

$\mathrm{T} 7=75 \%$ calc. dolomítico $+25 \%$ gesso 

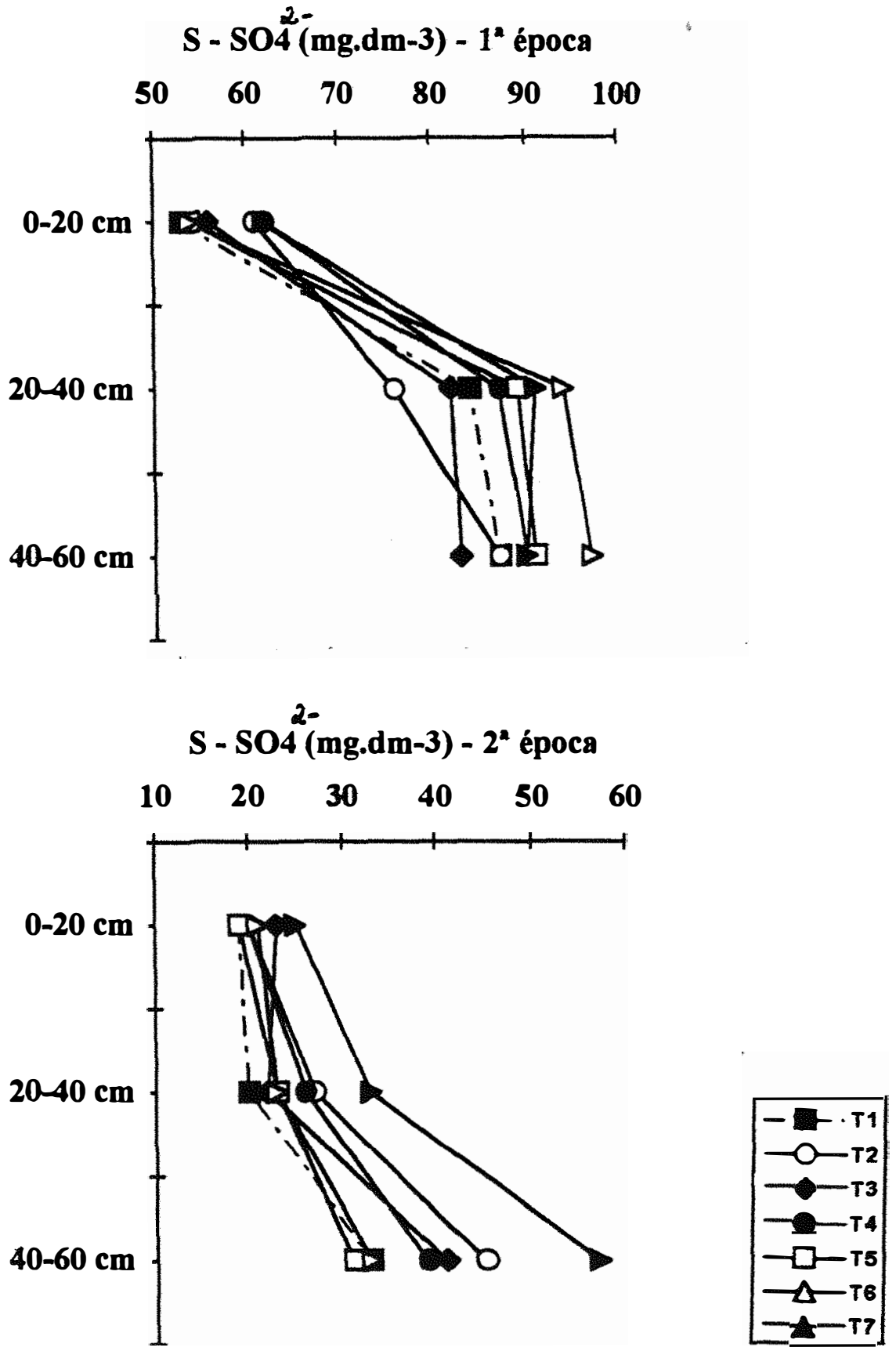

Figura 5 - Teores de $\mathrm{SO}_{4}{ }^{2-}\left(\mathrm{mg} \cdot \mathrm{dm}^{-3}\right)$ em 3 profundidades de solo na $1^{\text {a. }}$ e $2^{\mathrm{a} .}$ épocas de amostragem. 
área, antes da instalação do experimento $\left(112,99\right.$ e $74 \mathrm{mg} \cdot \mathrm{dm}^{-3}$, respectivamente para as profundidades: $0-20 \mathrm{~cm}, 20-40 \mathrm{~cm}$ e $40-60 \mathrm{~cm}$ ). A continuidade desta pesquisa, comprovará ou não esta hipótese.

Estudos sobre teores de $\mathrm{S}-\mathrm{SO}_{4}{ }^{2-}$ disponíveis em subsuperficie também foram desenvolvidos por CARVALHO (1994) tendo observado que o sulfato de cálcio e o fosfogesso aumentaram significativamente os teores de $\mathrm{S}-\mathrm{SO}_{4}{ }^{2-}$ em todos os solos estudados.

Aspectos semelhantes sobre a distribuição de $\mathrm{SO}_{4}{ }^{2-}$ no perfil do solo, foram também observados por MAZZA(1993), tendo evidenciado a rápida ação do gesso no solo. Logo aos 6 meses, após a aplicação do gesso, o $\mathrm{SO}_{4}{ }^{2-}$ apresentou sensíveis incrementos tanto na camada arável como em subsuperficie $(20-60 \mathrm{~cm})$, passando de $10 \mathrm{ppm}$ para $100-140 \mathrm{ppm}$ na profundidade de $0-20 \mathrm{~cm}$ e de 10 ppm para 40 a 50 ppm em subsuperficie. Aos 18 e 30 meses, houve decréscimos deste nutriente na camada arável, acompanhados de novos e proporcionais incrementos em subsuperficie.

Observações interessantes sobre a retenção de $\mathrm{SO}_{4}{ }^{2-}$ na camada arável, foram feitas por SOUSA \& RITCHEY (1986) ao citarem que a mistura de calcário e gesso favorecem a menor retenção de $\mathrm{SO}_{4}{ }^{2-}$ na camada arável do solo devido ao aumento do $\mathrm{pH}$ pela calagem. 
É interessante lembrar que a lixiviação de $\mathrm{SO}_{4}{ }^{2-}$ nos solos tem um comportamento semelhante ao do $\mathrm{NO}_{3}^{-}$(RAIJ, 1988) e por conseguinte, solos que adsorvem pouco $\mathrm{NO}_{3}^{-}$, sofrem consideráveis perdas de $\mathrm{SO}_{4}{ }^{2-}$ por lixiviação.

\subsubsection{V\%, SB, CTC, M.O. e P.}

As porcentagens de saturação por bases (V\%) estão apresentadas nas tabelas 22 ( $1^{\mathrm{a}}$ época de amostragem), 23 ( $2^{\mathrm{a} .}$ época de amostragem) e na figura 6 (gráficos representativos da $1^{\mathrm{a}}$ e $2^{\mathrm{a}}$ épocas de amostragem, nas 3 profundidades de solo).

Para a $1^{\text {a. }}$ época, os testes estatísticos utilizados ( $F$ e Tukey) revelaram um nivel de significância da ordem de $1 \%$ de probabilidade para os valores de $\mathrm{V} \%$ dentro de cada profundidade. No entanto, apenas a profundidade 0-20 cm apresentou valores de V\% mais próximos de $60 \%$, recomendado para citros, principalmente nos tratamentos $T_{4}$ (calcário magnesiano exclusivo) e $T_{5}$ (misturas de calcário dolomítico + calcário calcítico). Na profundidade de 20-40 $\mathrm{cm}$, o máximo valor de $\mathrm{V} \%$ atingido foi de $43,5 \%$ para o tratamento $\mathrm{T}_{5}$ que diferenciou significativamente dos demais. Na profundidade $40-60 \mathrm{~cm}$, o maior valor de $V \%$ encontrado foi de $37,8 \%$ para o tratamento $T_{4}$, diferindo apenas do tratamento $T_{6}(2 / 3$ calcário dolomítico $+1 / 3$ calcário calcítico), que apresentou a menor porcentagem de saturação por bases $(26,1 \%)$. 
Tabela 22 - Porcentagens de saturação por bases (V\%) em 3 profundidades de solo (1a. época de amostragem - safra 1992/93).

\begin{tabular}{cccc}
\hline TRATAMENTO & \multicolumn{3}{c}{ PROFUNDIDADE $(\mathrm{cm})$} \\
\cline { 2 - 4 } & $0-20$ & $20-40$ & $40-60$ \\
\hline T1 & $34,5 C$ & $30,8 B$ & $36,1 A$ \\
T3 & $40,5 B C$ & $34,3 B$ & $36,6 A$ \\
T4 & $42,0 B C$ & $29,0 B$ & $30,6 A B$ \\
T5 & $59,1 A$ & $31,8 B$ & $37,8 A$ \\
T6 & $59,8 A$ & $43,5 A$ & $32,6 A B$ \\
T7 & $51,0 A B$ & $27,8 B$ & $26,1 B$ \\
F & $50,5 A B C$ & $29,8 B$ & $29,8 A B$ \\
dms(1\%) & $10,39^{* *}$ & $13,42^{* *}$ & $7,35^{* *}$ \\
CV(\%) & 16,09 & 7,81 & 8,48 \\
\hline
\end{tabular}

Médias seguidas de mesmas letras maiúsculas, na vertical, não diferem estatisticamente pelo teste de Tukey a $1 \%$.

\section{LEGENDA}

$\mathrm{T} 1=$ Testemunha

$\mathrm{T} 2=$.Calcário dolomítico

$\mathrm{T} 3=$ Calcário calcítico

$\mathrm{T} 4=$ Calcário magnesiano
$\mathrm{T} 5=50 \%$ calc. dolomitico $+50 \%$ calc. calcítico

$\mathrm{T} 6=2 / 3$ calc. dolomítico $+1 / 3$ calc. calcítico

$\mathrm{T} 7=75 \%$ calc. dolomítico $+25 \%$ gesso 
Tabela 23 - Porcentagens de saturação por bases (V\%) em 3 profundidades de solo (2a. época de amostragem - safra 1993/94).

\begin{tabular}{cccc}
\hline TRATAMENTO & \multicolumn{3}{c}{ PROFUNDIDADE (cm) } \\
\cline { 2 - 4 } & $0-20$ & $20-40$ & $40-60$ \\
\hline T1 & $29,5 B$ & 23,6 & 19,6 \\
T2 & $34,5 A B$ & 23,6 & 21,1 \\
T3 & $41,0 A B$ & 29,3 & 26,3 \\
T4 & $43,6 A$ & 23,8 & 23,0 \\
T5 & $38,8 A B$ & 25,3 & 23,6 \\
T6 & $34,3 A B$ & 24,8 & 20,3 \\
T7 & $39,0 A B$ & 25,8 & 21,3 \\
F & $3,86^{* *}$ & $1,07 \mathrm{NS}$ & $0,94 \mathrm{NS}$ \\
$\mathrm{dms}(1 \%)$ & 13,11 & 10,45 & 12,77 \\
CV(\%) & 15,97 & 18,81 & 26,09
\end{tabular}

$\overline{\text { Médias seguidas de mesmas letras maiúsculas, na vertical, não diferem estatistica- }}$ mente pelo teste de Tukey a $1 \%$.

\section{LEGENDA}

$\mathrm{T} 1=$ Testemunha $\quad \mathrm{T} 5=50 \%$ calc. dolomítico $+50 \%$ calc. calcítico

$\mathrm{T} 2=$.Calcário dolomítico $\quad \mathrm{T} 6=2 / 3$ calc. dolomítico $+1 / 3$ calc. calcítico

$\mathrm{T} 3=$ Calcário calcítico $\quad \mathrm{T} 7=75 \%$ calc dolomítico $+25 \%$ gesso

$\mathrm{T} 4=$ Calcário magnesiano 

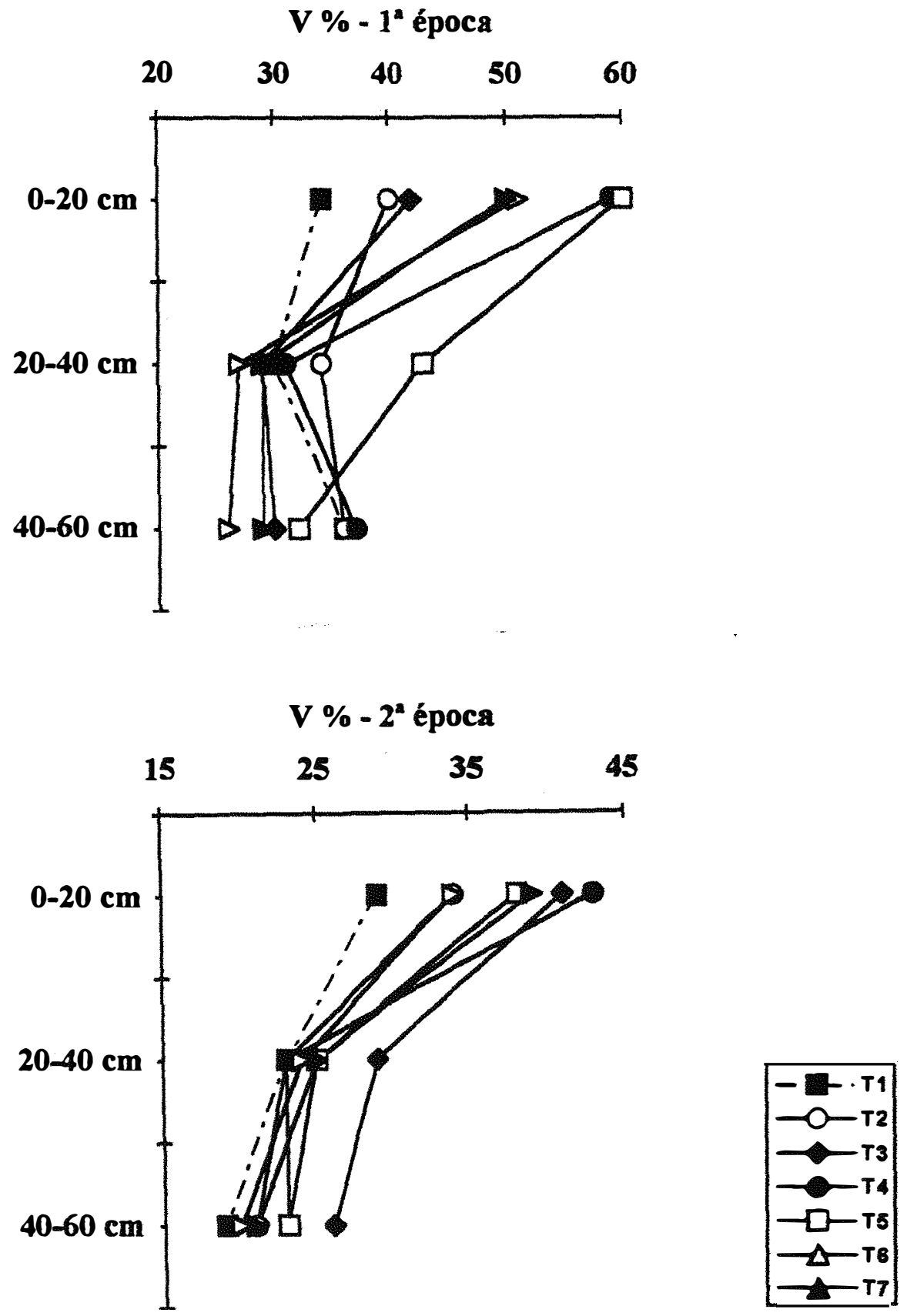

Figura 6 - Porcentagem de saturação por bases (V\%) em 3 profundidades de solo na $1^{\mathrm{a} .}$ e $2^{\mathrm{a}}$ épocas de amostragem. 
Por ocasião da instalação do experimento, os valores de V\% para as 3 profundidades foram: $34(0-20 \mathrm{~cm}), 19(20-40 \mathrm{~cm})$ e $29(40-60 \mathrm{~cm})$ - tabela 2 do item 3 (material e métodos). Então, 12 meses após a aplicação dos tratamentos, observa-se que houve um incremento considerável nos valores de V\%, mas estes valores ainda estão distantes da faixa ideal (60-70\%), recomendada por VITTI (1989), RAIJ (1991), VIOLANTE NETTO et al. (1988) e G.P.A.C.C. (1990), se considerarmos no cálculo de V\%, o valor da CTC atual. Por outro lado, se calcularmos o V\%, em relação a CTC original do solo, o que seria mais lógico, a saturação por bases atingirá a faixa ideal ou recomendada (60-70\%) para a maioria dos tratamentos aplicados. Ao se analisar os dados de V\% da tabela 23 ( $2^{\text {a. }}$ época de amostragem), a saturação fica ainda menor, pois os dados estão menores aqueles da $1^{\text {a }}$ época, portanto mais distantes da faixa ideal $(60-70 \%)$. Nesta $2^{\mathrm{a}}$ época, o maior valor de $\mathrm{V} \%$ encontrado foi de $43,60 \%$, para o tratamento $\mathrm{T}_{4}$ (calcário magnesiano exclusivo), na profundidade de $0-20 \mathrm{~cm}$. Nessa profundidade, a testemunha apresentou o menor valor de $\mathrm{V} \%=29,5$, diferindo significativamente do tratamento $\mathrm{T}_{4}$, a $1 \%$ de probabilidade.

A representação gráfica dos dados de $\mathrm{V} \%\left(1^{\mathrm{a} .}\right.$ e $2^{\mathrm{a}}$ épocas $)$ apresentada na figura 6, mostra que os maiores valores de V\% foram obtidos nas amostras coletadas na profundidade $0-20 \mathrm{~cm}$. Em subsuperfície, os valores de V\% decresceram até a profundidade de $60 \mathrm{~cm}$, na $2^{\mathrm{a}}$ época. 
Considerando que V\% está diretamente relacionada a soma de bases trocáveis do solo (SB), era de se esperar que a distribuição de seus valores, à nível de perfil de solo, fossem semelhantes. Nas tabelas 24 e 25 estão os teores da soma de bases trocáveis calculadas para a $1^{\text {a. }}$ e $2^{\text {a. }}$ épocas de amostragem de solo, respectivamente.

Em relação à $\mathrm{SB}$ da $1^{\mathrm{a}}$ época, os tratamentos diferiram significativamente a $1 \%$ de probabilidade, nas 3 profundidades estudadas, sendo que os maiores teores de SB foram encontrados para o tratamento $\mathrm{T}_{5}(50 \%$ calcário dolomítico $+50 \%$ calcário calcítico) em todas as profundidades.

Em relação à $\mathrm{SB}$ da $2^{\mathrm{a}}$ época, os tratamentos diferiram significativamente apenas na profundidade $0-20 \mathrm{~cm}$, a $5 \%$ de probabilidade sendo o maior valor de $\mathrm{SB}=48,1 \mathrm{mmol}_{\mathrm{c}} \cdot \mathrm{dm}^{-3}$, obtido com o tratamento $\mathrm{T}_{7}(75 \%$ calcário dolomítico $+25 \%$ gesso) que diferiu significativamente do menor valor $\mathrm{SB}=33,1 \mathrm{mmol}_{\mathrm{c}} \cdot \mathrm{dm}^{-3}$, obtido para a testemunha $\left(\mathrm{T}_{1}\right)$.

Os maiores valores de saturação por bases observados foram na camada arável aos 12 meses, após a aplicação das misturas de calcário dolomítico com calcário calcítico $(1: 1)$ e $(2 / 3: 1 / 3)$ e, da mistura de calcário dolomítico + gesso (3:1), tendo apresentado respectivamente, os seguintes valores: 60,$5 ; 58,8 \mathrm{e}$ 60,8 .

Em pesquisa sobre aplicação de calcário e gesso em cana-de-açúcar, MAZZA (1993), também observou que a SB sofreu incrementos na camada 
Tabela 24 - Soma de bases trocáveis - SB $\left(\mathrm{mmol}_{\mathrm{c}} \cdot \mathrm{dm}^{-3}\right)$ em 3 profundidades de solo (1a. época de amostragem - safra 1992/93).

\begin{tabular}{|c|c|c|c|}
\hline \multirow[t]{2}{*}{ TRATAMENTO } & \multicolumn{3}{|c|}{ PROFUNDIDADE $(\mathrm{cm})$} \\
\hline & $0-20$ & $20-40$ & $40-60$ \\
\hline $\mathrm{T} 1$ & $34,5 \mathrm{D}$ & $23,0 \mathrm{C}$ & $28,0 \quad D$ \\
\hline $\mathrm{T} 2$ & $46,0 B C D$ & $40,8 A B$ & $30,6 C D$ \\
\hline T3 & $48,5 A B C$ & $36,1 \quad B$ & $41,0 \quad B$ \\
\hline $\mathrm{T} 4$ & $42,6 C D$ & $35,3 \quad B$ & $39,0 \quad B$ \\
\hline T5 & $60,5 A$ & $51,3 \quad A$ & $57,1 \quad A$ \\
\hline T6 & $58,8 A B$ & $23,1 \quad c$ & $25,0 \quad D$ \\
\hline $\mathrm{T} 7$ & $60,8 A$ & $23,8 C$ & $38,5 B C$ \\
\hline $\mathrm{F}$ & $18,14^{* *}$ & $28,61^{* *}$ & $53,10^{* *}$ \\
\hline $\operatorname{dms}(1 \%)$ & 12,80 & 10,80 & 7,90 \\
\hline $\mathrm{CV}(\%)$ & 11,60 & 14,73 & 9,75 \\
\hline
\end{tabular}

Médias seguidas de mesmas letras maiúsculas, na vertical, não diferem estatisticamente pelo teste de Tukey a $1 \%$.

\section{LEGENDA}

$\mathrm{T} 1=$ Testemunha

$\mathrm{T} 2=$.Calcário dolomítico

$\mathrm{T} 3$ = Calcário calcítico

$\mathrm{T} 4=$ Calcário magnesiano
$\mathrm{T} 5=50 \%$ calc. dolomítico $+50 \%$ calc. calcítico

$\mathrm{T} 6=2 / 3$ calc. dolomítico $+1 / 3$ calc. calcítico

$\mathrm{T} 7=75 \%$ calc. dolomítico $+25 \%$ gesso 
Tabela 25 - Soma de bases trocáveis - SB $\left(\mathrm{mmol}_{\mathrm{c}} \cdot \mathrm{dm}^{-3}\right)$ em 3 profundidades de solo (2a. época de amostragem - safra 1993/94).

\begin{tabular}{cccc}
\hline TRATAMENTO & \multicolumn{3}{c}{ PROFUNDIDADE $(\mathrm{cm})$} \\
\cline { 2 - 4 } & $0-20$ & $20-40$ & $40-60$ \\
\hline T2 & $33,1 b$ & 26,0 & 20,0 \\
T3 & $41,3 a b$ & 25,6 & 20,1 \\
T4 & $41,3 a b$ & 30,1 & 22,5 \\
T5 & $41,5 a b$ & 23,8 & 21,3 \\
T6 & $38,5 a b$ & 26,1 & 21,0 \\
T7 & $39,0 a b$ & 27,0 & 19,5 \\
F & $48,1 a$ & 26,6 & 20,5 \\
dms(5\%) & $1,88^{*}$ & $0,92 \mathrm{NS}$ & $0,25 \mathrm{NS}$ \\
CV(\%) & 14,60 & 8,80 & 8,80 \\
\hline
\end{tabular}

$\overline{\text { Médias seguidas de mesmas letras minúsculas, na vertical, não diferem estatistica- }}$ mente pelo teste de Tukey a 5\%.

\section{LEGENDA}

$\mathrm{T} 1=$ Testemunha $\quad \mathrm{T} 5=50 \%$ calc. dolomítico $+50 \%$ calc. calcítico

$\mathrm{T} 2=$. Calcário dolomítico $\quad \mathrm{T} 6=2 / 3$ calc. dolomítico $+1 / 3$ calc. calcítico

$\mathrm{T} 3=$ Calcário calcítico $\quad \mathrm{T} 7=75 \%$ calc . dolomítico $+25 \%$ gesso

$\mathrm{T} 4=$ Calcário magnesiano 
superficial do solo, logo aos 6 meses após a aplicação das doses de calcário e gesso, devido a elevação dos teores de $\mathrm{Ca}^{2+}$ proporcionado pelo calcário e gesso e a elevação do $\mathrm{Mg}^{2+}$, basicamente em função do calcário, uma vez que o $\mathrm{K}^{+}$ apresentou poucas modificações. Na camada de $20-40 \mathrm{~cm}$, os incrementos observados na SB foram também devidos às adições de doses crescentes de calcário e gesso que elevaram o teor de $\mathrm{Ca}^{2+}$ e pelas doses de calcário que incrementaram o teor de $\mathrm{Mg}^{2+}$. As 2 maiores doses de calcário utilizadas $(1,4 \mathrm{e}$ $2,8 \mathrm{t} / \mathrm{ha}$ ) mantiveram a saturação por bases na camada superficial acima de $50 \%$, no período de 6 a 30 meses, após a aplicação desses produtos corretivos, independentes das combinações com o gesso.

Resultados concordantes sobre a saturação por bases, em pesquisa sobre calcário e gesso em cana-de-açúcar, também foram obtidos por ROLIM (1995), tendo observado que todos os produtos e misturas estudadas elevaram a saturação por bases da camada arável, aos 6 meses após a aplicação dos produtos. Por ocasião da colheita da cana-planta, detectou-se maiores niveis de saturação por bases apenas na camada arável, em todos os tratamentos, com exceção do gesso e da testemunha. Após a colheita da $2^{\mathrm{a} .}$ soca (40 meses após aplicação dos produtos), observou-se que a mistura de gesso + magnesita foi o único tratamento que proporcionou valores de saturação por bases na camada arável, ao redor de $50 \%$. Todos os demais tratamentos, em qualquer camada do perfil do solo analisado, apresentaram valores de $\mathrm{V} \%$ mais baixos. 
Com relação a capacidade de troca de cátions (tabelas 26 e 27), todos os tratamentos não diferiram estatisticamente em nenhuma das 3 profundidades, nas 2 épocas de amostragem de solo.

Os teores de matéria orgânica (M.O.) obtidos nas 3 profundidades estão nas tabelas 28 ( $1^{\text {a. }}$ época) e 29 ( $2^{\text {a. }}$ época). Estes teores não diferiram estatisticamente em relação aos tratamentos aplicados em nenhuma das 3 profundidades, nas 2 épocas de amostragem. Comparando-se os teores de M.O. numa mesma profundidade, entre as 2 épocas, observou-se pequenos decréscimos

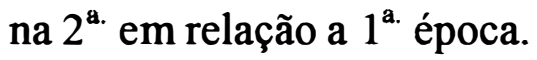

A análise inicial do solo (antes da instalação do experimento) apresentou os teores de 33,33 e $22{\mathrm{~g} . \mathrm{dm}^{-3}}^{-3}$, respectivamente para as profundidades de $0-20 \mathrm{~cm} ; 20-40 \mathrm{~cm}$ e $40-60 \mathrm{~cm}$. Vê-se pelos teores de M.O. apresentados nas tabelas 28 e 29 que houve pequenas variações entre as épocas, nas 3 profundidades.

Tendo em vista que a calagem aumenta a disponibilidade de fósforo no solo, analisou-se os teores de $\mathrm{P}$ nas 3 profundidades, nas 2 épocas de amostragem e, estes resultados são apresentados nas tabelas 30 e 31 e figura 7 .

Na $1^{\text {a. }}$ época (tabela 30 ), alguns tratamentos diferiram significativamente a $1 \%$ de probabilidade nas 3 profundidades. Os maiores teores foram encontrados na profundidade $0-20 \mathrm{~cm}$, decrescendo consideravelmente em subsuperficie $(20-40 \mathrm{~cm} \mathrm{e} 40-60 \mathrm{~cm})$. O maior teor de $\mathrm{P}\left(38 \mathrm{mg} \cdot \mathrm{dm}^{-3}\right)$ foi obtido 
Tabela 26 - Capacidade de troca de cátions - CTC $\left(\mathrm{mmol}_{\mathrm{c}} \cdot \mathrm{dm}^{-3}\right)$ em 3 profundidades de solo (1a. época de amostragem - safra 1992/93).

\begin{tabular}{cccc}
\hline TRATAMENTO & \multicolumn{3}{c}{ PROFUNDIDADE (cm) } \\
\cline { 2 - 4 } & $0-20$ & $20-40$ & $40-60$ \\
\hline T1 & 112,5 & 110,0 & 100,6 \\
T3 & 115,3 & 118,5 & 106,6 \\
T4 & 114,8 & 114,3 & 99,9 \\
T5 & 114,1 & 109,5 & 96,0 \\
T6 & 125,1 & 115,3 & 101,8 \\
T7 & 120,8 & 121,6 & 102,3 \\
\hline F & 122,5 & 112,3 & 104,8 \\
dms(5\%) & $0,85 \mathrm{NS}$ & $0,63 \mathrm{NS}$ & $0,64 \mathrm{NS}$ \\
CV(\%) & 23,30 & 24,80 & 19,10 \\
\hline
\end{tabular}

\section{LEGENDA}

$\mathrm{T} 1=$ Testemunha

$\mathrm{T} 2=$.Calcário dolomítico

$\mathrm{T} 3$ = Calcário calcítico

$\mathrm{T} 4=$ Calcário magnesiano
$\mathrm{T} 5=50 \%$ calc. dolomítico $+50 \%$ calc. calcítico

$\mathrm{T} 6=2 / 3$ calc. dolomítico $+1 / 3$ calc. calcítico

$\mathrm{T} 7=75 \%$ calc. dolomítico $+25 \%$ gesso 
Tabela 27 - Capacidade de troca de cátions - CTC $\left(\mathrm{mmol}_{\mathrm{c}} \cdot \mathrm{dm}^{-3}\right)$ em 3 profundidades de solo (2a. época de amostragem - safra 1993/94).

\section{TRATAMENTO PROFUNDIDADE $(\mathrm{cm})$}

\begin{tabular}{cccc}
\cline { 2 - 3 } & $0-20$ & $20-40$ & $40-60$ \\
\hline T1 & 122,0 & 103,3 & 92,6 \\
T3 & 109,3 & 109,0 & 96,5 \\
T4 & 97,6 & 98,8 & 86,5 \\
T5 & 103,5 & 100,6 & 87,5 \\
T6 & 99,0 & 101,8 & 90,5 \\
T7 & 109,8 & 108,6 & 95,4 \\
F & 112,3 & 104,3 & 96,5 \\
dms(5\%) & $2,23 \mathrm{NS}$ & $0,69 \mathrm{NS}$ & $0,97 \mathrm{NS}$ \\
$\mathrm{CV}(\%)$ & 25,10 & 20,70 & 18,90 \\
\hline
\end{tabular}

LEGENDA:

$\mathrm{T} 1=$ Testemunha

$\mathrm{T} 2=$. Calcário dolomítico

$\mathrm{T} 3=$ Calcário calcítico

T4= Calcário magnesiano
$\mathrm{T} 5=50 \%$ calc. dolomítico $+50 \%$ calc. calcítico

$\mathrm{T} 6=2 / 3$ calc. dolomítico $+1 / 3$ calc. calcítico

$\mathrm{T} 7=75 \%$ calc. dolomítico $+25 \%$ gesso 
Tabela 28 - Teores de matéria orgânica - M.O. $\left(\mathrm{g} \cdot \mathrm{dm}^{-3}\right)$ em 3 profundidades de solo (1a. época de amostragem - Safra 1992/93).

\begin{tabular}{cccc}
\hline TRATAMENTO & \multicolumn{3}{c}{ PROFUNDIDADE (cm) } \\
\cline { 2 - 4 } & $0-20$ & $20-40$ & $40-60$ \\
\hline T1 & 34,3 & 29,0 & 26,3 \\
T3 & 32,5 & 30,5 & 28,5 \\
T4 & 33,8 & 27,5 & 25,0 \\
T5 & 34,0 & 29,0 & 26,0 \\
T6 & 34,8 & 29,1 & 27,8 \\
T7 & 33,5 & 28,0 & 25,8 \\
\hline F & 34,6 & 28,6 & 27,1 \\
\hline dms(5\%) & 1,07 NS & $0,61 \mathrm{NS}$ & $0,61 \mathrm{NS}$ \\
CV(\%) & 3,40 & 5,40 & 6,90 \\
\hline
\end{tabular}

\section{LEGENDA:}

$\mathrm{T} 1=$ Testemunha

$\mathrm{T} 2$ = . Calcário dolomítico

$\mathrm{T} 3$ = Calcário calcítico

$\mathrm{T} 4$ = Calcário magnesiano
$\mathrm{T} 5=50 \%$ calc. dolomítico $+50 \%$ calc. calcítico

$\mathrm{T} 6=2 / 3$ calc. dolomítico $+1 / 3$ calc. calcítico

$\mathrm{T} 7=75 \%$ calc. dolomítico $+25 \%$ gesso 
Tabela 29 - Teores de matéria orgânica -M.O. $\left(\mathrm{g} \cdot \mathrm{dm}^{-3}\right)$ em 3 profundidades de solo (2a. época de amostragem - Safra 1993/94).

\begin{tabular}{cccc}
\hline TRATAMENTO & \multicolumn{3}{c}{ PROFUNDIDADE (cm) } \\
\cline { 2 - 4 } & $0-20$ & $20-40$ & $40-60$ \\
\hline T1 & 27,6 & 25,6 & 22,1 \\
T2 & 28,5 & 24,5 & 21,5 \\
T3 & 26,1 & 24,3 & 20,3 \\
T4 & 28,0 & 24,1 & 21,5 \\
T5 & 30,5 & 28,0 & 25,3 \\
T6 & 30,3 & 24,6 & 20,5 \\
T7 & 30,8 & 27,8 & 24,3 \\
\hline F & $0,75 \mathrm{NS}$ & $0,93 \mathrm{NS}$ & $1,28 \mathrm{NS}$ \\
dms(5) & 8,90 & 7,60 & 7,40 \\
CV(\%) & 17,00 & 16,42 & 18,48 \\
\hline
\end{tabular}

\section{LEGENDA:}

$$
\begin{array}{ll}
\mathrm{T} 1=\text { Testemunha } & \mathrm{T} 5=50 \% \text { calc. dolomítico }+50 \% \text { calc. calcítico } \\
\mathrm{T} 2=\text {. Calcário dolomítico } & \mathrm{T} 6=2 / 3 \text { calc. dolomítico }+1 / 3 \text { calc. calcítico } \\
\mathrm{T} 3=\text { Calcário calćtico } & \mathrm{T} 7=75 \% \text { calc. dolomítico }+25 \% \text { gesso } \\
\mathrm{T} 4=\text { Calcário magnesiano } &
\end{array}
$$


Tabela 30 - Teores de P em (mg.dm ${ }^{-3}$ ) em 3 profundidades de solo (1a. época de amostragem - Safra 1992/93). PROFUNDIDADE $(\mathrm{cm})$

\begin{tabular}{cccc}
\hline & $0-20$ & $20-40$ & $40-60$ \\
\cline { 2 - 4 } T1 & $29 B C$ & $12 A$ & $6 a b$ \\
T3 & $23 C$ & $11 A$ & $6 a b$ \\
T4 & $23 C$ & $8 C$ & $7 a b$ \\
T5 & $23 C$ & $11 A$ & $8 a$ \\
T6 & $38 A$ & $11 A$ & $5 b$ \\
T7 & $26 B C$ & $11 A B$ & $6 a b$ \\
F & $30 B$ & $9 B C$ & $7 a b$ \\
dms(5\%) & $19,03 * *$ & $21,00^{* *}$ & $3,17^{* *}$ \\
dms(1\%) & 5,74 & 1,51 & 2,77 \\
CV(\%) & 6,95 & 1,83 & 3,36 \\
\hline
\end{tabular}

Médias seguidas de mesmas letras minúsculas ou maiúsculas, na vertical, não diferem estatisticamente pelo teste de Tukey $5 \%$ e $1 \%$, respectivamente.

\section{LEGENDA}

$\mathrm{T} 1=$ Testemunha

$\mathrm{T} 2=$.Calcário dolomítico

$\mathrm{T} 3$ = Calcário calcítico

$\mathrm{T} 4$ = Calcário magnesiano
$\mathrm{T} 5=50 \%$ calc. dolomítico $+50 \%$ calc. calcítico

$\mathrm{T} 6=2 / 3$ calc. dolomítico $+1 / 3$ calc. calcítico

$\mathrm{T} 7=75 \%$ calc. dolomítico $+25 \%$ gesso 
Tabela 31 - Teores P em (mg.dm ${ }^{-3}$ ) em 3 profundidades de solo (2a. época de amostragem - Safra 1993/94).

\begin{tabular}{cccc}
\hline TRATAMENTO & \multicolumn{3}{c}{ PROFUNDIDADE $(\mathrm{cm})$} \\
\cline { 2 - 4 } & $0-20$ & $20-40$ & $40-60$ \\
T2 & $7 C$ & 4 & $2 B C$ \\
T3 & $11 B$ & 5 & $2 B C$ \\
T4 & $7 C$ & 5 & $2 C$ \\
T5 & $15 A$ & 4 & $4 A$ \\
T6 & $12 B$ & 4 & $2 B C$ \\
T7 & $8 C$ & 5 & $2 C$ \\
F & $12 A B$ & 4 & $3 B$ \\
dms(1\%) & 2,40 & $0,89 \mathrm{NS}$ & $11,62^{* *}$ \\
CV(\%) & 10,28 & 2,35 & 1,38 \\
\hline
\end{tabular}

$\overline{\text { Médias seguidas de mesmas letras maiúsculas, na vertical, não diferem estatistica- }}$ mente pelo teste de Tukey a $1 \%$.

\section{LEGENDA}

$\mathrm{T} 1=$ Testemunha

$\mathrm{T} 2=$. Calcário dolomítico

$\mathrm{T} 3$ = Calcário calcítico

$\mathrm{T} 4$ = Calcário magnesiano
$\mathrm{T} 5=50 \%$ calc. dolomítico $+50 \%$ calc. calcítico

$\mathrm{T} 6=2 / 3$ calc. dolomítico $+1 / 3$ calc. calcítico

$\mathrm{T} 7=75 \%$ calc. dolomitico $+25 \%$ gesso 

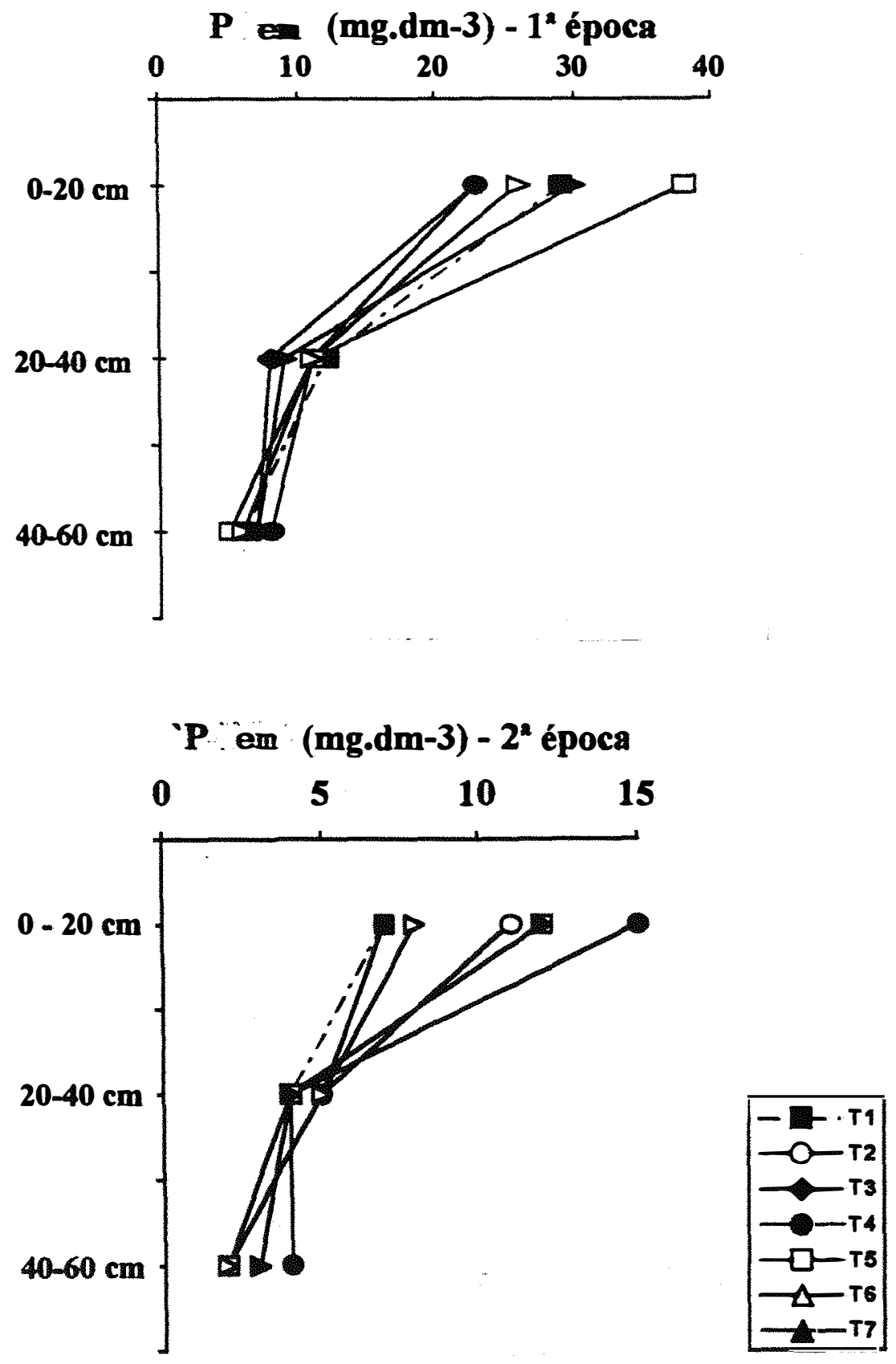

Figura 7 - Teores de $\mathrm{P}$ em $\quad\left(\mathrm{mg} . \mathrm{dm}^{-3}\right)$ em 3 profundidades de solo na $1^{\mathrm{a} .}$ e $2^{\mathrm{a}}$ épocas de amostragem. 
na profundidade $0-20 \mathrm{~cm}$ com o tratamento $\mathrm{T}_{5}(50 \%$ de calcário dolomítico + $50 \%$ de calcário calcítico) que diferiu significativamente dos demais tratamentos. Os menores teores foram encontrados na profundidade de 40-60 cm. Apenas os ratamentos $\mathrm{T}_{4}$ e $\mathrm{T}_{5}$ diferiram significativamente entre si a $1 \%$ de probabilidade.

$\mathrm{Na} 2^{\mathrm{a}}$ época de avaliação (tabela 31 ), os teores de $\mathrm{P}$ foram bem menores que os obtidos na $1^{\text {a. }}$ época. Houve diferenças significativas entre alguns tratamentos nas profundidades $0-20 \mathrm{~cm}$ e $40-60 \mathrm{~cm}$.

Os teores de $\mathrm{P}$, antes da instalação do experimento, foram: 15, 6 e 2 mg.dm ${ }^{-3}$, respectivamente para as profundidades $0-20 \mathrm{~cm}, 20-40 \mathrm{~cm}$ e $40-60 \mathrm{~cm}$. Esses teores aumentaram sensivelmente até 12 meses após a aplicação dos tratamentos e depois decresceram significativamente no perfil do solo, até 24 meses após a aplicação dos tratamentos.

Este comportamento do P no solo foi semelhante ao comportamento dos resultados de produção de laranja obtidos nas 3 últimas safras, ou seja, os resultados da safra 91/92 (antes da instalação do experimento) foram menores que

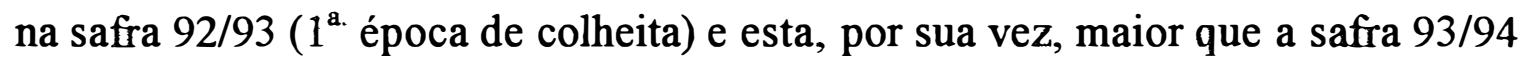
( $2^{\text {a. }}$ época de colheita). $\mathrm{O}$ decréscimo na produção ( $\left.\mathrm{t} / \mathrm{ha}\right)$ de laranja obtido na última safra (93/94), parece estar associado a problemas nutricionais, tais como: decréscimos de teores de $\mathrm{P}$ residual do solo e decréscimos dos teores de $\mathrm{Ca}^{2+}$, $\mathrm{Mg}^{2+} \mathrm{e} \mathrm{K}^{+}$disponíveis às plantas, principalmente nas profundidades de $0-20 \mathrm{~cm} \mathrm{e}$ 
$20-40 \mathrm{~cm}$. Talvez seja interessante rever os parâmetros nos quais se baseiam as futuras indicações de adubação básica (NPK) para a cultura, nas próximas safras.

\subsection{Efeitos dos tratamentos na planta}

\subsubsection{Macro e micronutrientes}

Os teores de macronutrientes em g. $\mathrm{Kg}^{-1}$ estão apresentados nas tabelas 32 e 33 , respectivamente, $1^{\text {a. }}$ e $2^{\text {a }}$ épocas de amostragem de folhas.

Os tratamentos aplicados não diferiram significativamente para nenhum dos macronutrientes, nas 2 épocas de avaliação.

Desta forma, os teores dos macronutrientes serão comentados, segundo suas faixas de interpretação: deficiente, baixo, adequado, alto e excessivo, de acordo com recomendações do G.P.A.C.C. (1990).

$\mathrm{Na} 1^{\text {a. }}$ época, os teores de nitrogênio, cálcio e enxôfre estavam adequados na planta; o potássio e o magnésio, apresentaram teores baixos e o teor de fósforo foi deficiente.

$\mathrm{Na} 2^{\text {a. }}$ época, apenas o teor de magnésio esteve baixo. Os demais macronutrientes estavam na faixa adequada. Ressalte-se o enxofre, cujo maior teor $\left(4,1 \mathrm{~g} \cdot \mathrm{Kg}^{-1}\right)$, obtido com o tratamento $\mathrm{T}_{3}$ (calcário calcítico), foi considerado alto. 
TABELA 32 - Teores de macronutrientes $\left(\mathrm{g} \cdot \mathrm{Kg}^{-1}\right)$ em folhas da laranjeira Hamlin (1a. época de colheita - safra 1992/93)

\begin{tabular}{ccccccc}
\hline TRATA- & \multicolumn{5}{c}{$\mathrm{g} \cdot \mathrm{Kg}^{-1}$} \\
MENTO & $\mathrm{N}$ & $\mathrm{P}$ & $\mathrm{K}$ & $\mathrm{Ca}$ & $\mathrm{Mg}$ & $\mathrm{S}$ \\
\cline { 2 - 7 } T1 & 24,5 & 0,9 & 9,9 & 33,9 & 2,2 & 2,9 \\
$\mathrm{~T} 2$ & 26,3 & 0,9 & 9,7 & 33,8 & 2,4 & 2,7 \\
$\mathrm{~T} 3$ & 26,2 & 0,8 & 10,2 & 36,6 & 2,4 & 3,1 \\
T4 & 26,7 & 0,8 & 10,5 & 36,7 & 2,0 & 2,8 \\
T5 & 26,2 & 0,9 & 10,0 & 36,3 & 2,6 & 2,6 \\
T6 & 26,8 & 0,9 & 9,1 & 34,1 & 2,4 & 2,7 \\
T7 & 26,6 & 0,9 & 10,3 & 39,4 & 2,4 & 2,7 \\
\hline F & $1,24 \mathrm{NS}$ & $1,01 \mathrm{NS}$ & $0,38 \mathrm{NS}$ & $1,15 \mathrm{NS}$ & $1,16 \mathrm{NS}$ & $0,98 \mathrm{NS}$ \\
$\mathrm{dms}(5 \%)$ & 3,10 & 0,20 & 3,30 & 8,50 & 0,70 & 0,70 \\
CV(\%) & 6,55 & 14,23 & 18,62 & 13,02 & 16,32 & 14,74 \\
\hline
\end{tabular}

\section{LEGENDA :}

$$
\begin{array}{ll}
\mathrm{T} 1=\text { Testemunha } & \mathrm{T} 5=50 \% \text { calc. dolomítico }+50 \% \text { calc. calcítico } \\
\mathrm{T} 2=\text {. Calcário dolomítico } & \mathrm{T} 6=2 / 3 \text { calc. dolomítico }+1 / 3 \text { calc. calcítico } \\
\mathrm{T} 3=\text { Calcário calćtico } & \mathrm{T} 7=75 \% \text { calc. dolomítico }+25 \% \text { gesso } \\
\mathrm{T} 4=\text { Calcário magnesiano } &
\end{array}
$$


TABELA 33- Teores de macronutrientes $\left(\mathrm{g} \cdot \mathrm{Kg}^{-1}\right)$ em folhas da laranjeira Hamlin (2a. época de colheita - safra 1993/94)

\begin{tabular}{|c|c|c|c|c|c|c|}
\hline TRATA- & & & g.kg- ${ }^{-1}$ & & & \\
\hline MENTO & $\bar{N}$ & $\bar{P}$ & $\bar{K}$ & $\mathrm{Ca}$ & $\mathrm{Mg}$ & $S$ \\
\hline $\mathrm{T} 1$ & 25,4 & 1,3 & 11,9 & 40,3 & 2,2 & 3,7 \\
\hline $\mathrm{T} 2$ & 25,1 & 1,3 & 11,1 & 40,8 & 2,0 & 3,7 \\
\hline T3 & 24,8 & 1,2 & 11,1 & 42,9 & 1,8 & 4,1 \\
\hline T4 & 25,7 & 1,2 & 11,0 & 42,3 & 2,0 & 3,6 \\
\hline T5 & 24,7 & 1,2 & 11,6 & 40,4 & 2,1 & 3,6 \\
\hline T6 & 26,0 & 1,2 & 11,0 & 39,5 & 2,1 & 3,5 \\
\hline $\mathrm{T} 7$ & 25,6 & 1,2 & 10,7 & 40,4 & 2,0 & 3,9 \\
\hline$F$ & $1,16 \mathrm{NS}$ & $1,54 \mathrm{NS}$ & $0,71 \mathrm{NS}$ & $0,27 \mathrm{NS}$ & $0,61 \mathrm{NS}$ & $1,39 \mathrm{NS}$ \\
\hline $\operatorname{dms}(5 \%)$ & 1,90 & 0,10 & 2,20 & 10,40 & 0,70 & 0,80 \\
\hline $\mathrm{CV}(\%)$ & 4,25 & 6,04 & 10,87 & 13,93 & 19,57 & 11,92 \\
\hline
\end{tabular}

\section{LEGENDA :}

$$
\begin{array}{ll}
\mathrm{T} 1=\text { Testemunha } & \mathrm{T} 5=50 \% \text { calc. dolomítico }+50 \% \text { calc. calcítico } \\
\mathrm{T} 2=\text {. Calcário dolomítico } & \mathrm{T} 6=2 / 3 \text { calc. dolomítico }+1 / 3 \text { calc. calcítico } \\
\mathrm{T} 3=\text { Calcário calcítico } & \mathrm{T} 7=75 \% \text { calc. dolomítico }+25 \% \text { gesso } \\
\mathrm{T} 4=\text { Calcário magnesiano } &
\end{array}
$$


O baixo teor do potássio encontrado nas folhas na $1^{\text {a. }}$ época, provavelmente, seja devido a 2 fatores: $1^{0}$ ) o nível de adubação potássica foi insuficiente; $2^{0}$ ) as doses e misturas de calcário e gesso utilizadas tenham promovido a lixiviação do potássio do solo, além da profundidade onde se encontrava a maior parte da rizosfera e, como consequência, da falta deste nutriente no solo, houve carência na planta. $\mathrm{Na} 2^{\mathrm{a} .}$ época de amostragem, o teor de $\mathrm{K}^{+}$foi normalizado na planta, provavelmente devido a aplicação da adubação básica e dos efeitos positivos e indiretos proporcionados pela calagem e gessagem, promovendo liberações de $\mathrm{K}^{+}$para a solução do solo ou até mesmo, proporcionando melhores condições para absorção de nutrientes pelas plantas.

Os teores de fósforo na planta mostraram-se deficientes na $1^{\mathrm{a} \cdot}$ época e adequados na $2^{\text {a. época. }}$

Esses baixos teores de fósforo encontrados nas folhas na $1^{\mathrm{a}}$ época, provavelmente tenham sido corrigidos no solo, pelas mesmas formas sugeridas para o potássio, não aparecendo esta deficiência nas folhas, por ocasião da $2^{\text {a. }}$ amostragem.

Apenas os teores de magnésio estiveram baixos, nas duas épocas de amostragem. Alguns pesquisadores tem procurado estabelecer correlações entre a sua disponibilidade no solo e os teores existentes nas folhas, mas os resultados são um pouco conflitantes, pois existem dúvidas quanto aos critérios de avaliação 
da sua disponibilidade, tendo em vista as diferentes condições de solo e os diversos níveis de interação que ele mantém com outros nutrientes.

Recentemente, QUAGGIO (1991) combinou doses de calcário calcítico e dolomítico tentando estabelecer níveis diferentes de magnésio no solo a fim de elaborar critérios de avaliação da disponibilidade e observou que não existiu correlação entre os teores de magnésio nas folhas com os teores deste nutriente no solo, quando as amostras de terra são coletadas na projeção da copa. Esse mesmo autor argumenta ainda que a amostragem de solo nas entrelinhas, dá uma razoável correlação e explica parcialmente a relação existente entre teores no solo e na planta.

De qualquer maneira, esperava-se obter nas folhas níveis adequados de magnésio pelo menos no tratamento com calcário dolomítico. Isto não aconteceu, pois o teor de magnésio esteve entre 1,8 e $2,6 \mathrm{~g} \cdot \mathrm{Kg}^{-1}$ (teores baixos), nas duas épocas de amostragem. Com base nos resultados obtidos, discorda-se das observações feitas por AVERNA-SACCÁ ${ }^{6}$, SPENCER \& WANDER ${ }^{7}$ e $\mathrm{KOO}^{8}$ citados por QUAGGIO (1991), quanto a eficácia de 3 tha de calcário dolomítico, como fonte eficiente de magnésio para a planta cítrica.

\footnotetext{
${ }^{6}$ AVERNA-SACCÁ, R. A clorose da laranjeira e de outras plantas nas terras ferruginosas. Boletim de Agricultura, São Paulo, 13:129-50, 1912.

${ }^{7}$ SPENCER, W.F. \& WANDER, I.W. A comparison of mangesium sources for young orange trees. Proceedings of the Florida State Horticultural Society, Winter Haven, 73:28-35, 1960.

${ }^{8}$ KOO, R.C. A comparison of magnesium sources for citrus. Soil and crop Science Society of Florida. Proceedings, Gainesville, 31 : $137-40,1971$
} 
Existem observações na literatura sobre teores de magnésio no solo, argumentando que se o teor de magnésio no solo foi superior a $0,8 \mathrm{meq} / 100 \mathrm{~cm}^{3}$ $\left(8,0 \mathrm{mmol}_{\mathrm{c}} \cdot \mathrm{dm}^{-3}\right)$, praticamente não ocorreu deficiências foliares na planta. Durante o desenvolvimento desta pesquisa, realmente não foram observados sintomas de deficiência de magnésio nas folhas e os teores deste elemento no solo estiveram adequados. Isto não explica a razão dos teores nas folhas terem se apresentado baixos, nas 2 épocas de amostragem.

Embora os resultados de $\mathrm{Ca}^{2+}$ trocável no solo tenham sido suficientes, devido a aplicação de corretivos e gesso, e os seus teores nas folhas tenham sido adequados, sugere-se cuidados, no caso da laranja, quanto a sua manutenção em teores adequados para garantir um bom equilíbrio da relação $\mathrm{Ca}^{2+} / \mathrm{K}^{+}$, principalmente por 3 motivos: $1^{\circ}$ ) as plantas cítricas são altamente exigentes em $\mathrm{Ca}^{2+}$, principalmente na fase de formação da laranjeira e, a absorção desse nutriente é aumentada com o aumento dessa relação no solo; $2^{\circ}$ ) existe uma correlação estreita entre a relação $\mathrm{Ca}^{2+} / \mathrm{K}^{+}$e a produção de laranja; $3^{0}$ ) há uma maior intensidade de absorção de cálcio na projeção da copa, região onde é aplicada a adubação de produção, na qual os teores de $\mathrm{K}^{+}$são elevados, o suficiente para abaixar a relação $\mathrm{Ca}^{2+} / \mathrm{K}^{+}$e comprometer a produtividade da cultura.

Sabe-se que o $\mathrm{K}^{+}$é o nutriente mais antagônico em relação a outras bases e este antagonismo é ainda mais evidente com o $\mathrm{Ca}^{2+}$ do que com o $\mathrm{Mg}^{2+}$. 
Daí a grande preocupação com as adições indiscriminadas de nutrientes e de calcário ao solo, pois fatalmente, vão afetar estas relações no solo e prejudicar o processo de absorção de nutrientes pela laranjeira, principalmente do potássio.

Os teores de micronutrientes ( $\mathrm{B}, \mathrm{Cu}, \mathrm{Fe}, \mathrm{Mn}$ e $\mathrm{Zn}$ ) encontrados nas folhas foram expressos em mg. $\mathrm{Kg}^{-1}$ e estão nas tabelas 34 e 35, respectivamente, $1^{\mathrm{a} .}$ e $2^{\mathrm{a} .}$ épocas de amostragem.

À similaridade dos macronutrientes, os tratamentos aplicados não diferiram significativamente os teores de micronutrientes obtidos em nenhuma das épocas de avaliação.

A análise de seus teores, segundo as faixas de interpretação proposta pelo G.P.A.C.C. (1990), permite observar que: a) na $1^{\text {a. }}$ época de amostragem, os teores de $\mathrm{Fe}$ estavam excessivos, os teores de $\mathrm{Zn}$, $\mathrm{Mn}$ e $\mathrm{Cu}$, adequados e os teores de B estavam deficientes; b) na $2^{\mathrm{a} .}$ época de amostragem, os teores de Fe continuaram excessivos, os teores de $\mathrm{Zn}$ e Mn continuaram altos, mas os teores de $\mathrm{Cu}$, decresceram e ficaram na faixa de deficiente e, os teores de $\mathrm{B}$ aumentaram nas folhas para a faixa de adequado. Em síntese, apenas os teores de $\mathrm{B}$ na $1^{\mathrm{a} .}$ época e de $\mathrm{Cu}$ na $2^{\mathrm{a} .}$ época, mostraram-se baixos nas plantas. Os teores dos demais micronutrientes já estavam adequados nas folhas, na $1^{\text {a. }}$ época e continuaram adequados ou sofreram incrementos na $2^{\text {a }}$ época de amostragem.

A distribuição destes micronutrientes nas folhas de laranjeira, 
TABELA 34- Teores de micronutrientes $\left(\mathrm{mg} \cdot \mathrm{Kg}^{-1-}\right)$ em folhas da laranjeira Hamlin (1a. época de colheita - safra 1992/93)

\begin{tabular}{cccccc}
\hline & \multicolumn{5}{c}{${\mathrm{mg} \cdot \mathrm{kg}^{-1}}^{-1}$} \\
\cline { 2 - 6 } TRATAMENTO & $\mathrm{B}$ & $\mathrm{Cu}$ & $\mathrm{Fe}$ & $\mathrm{Mn}$ & $\mathrm{Zn}$ \\
\cline { 2 - 6 } T2 & 8 & 7 & 484 & 44 & 43 \\
T3 & 8 & 7 & 500 & 43 & 40 \\
T4 & 9 & 8 & 506 & 43 & 42 \\
T5 & 70 & 7 & 437 & 46 & 46 \\
T6 & 8 & 6 & 433 & 43 & 50 \\
T7 & 9 & 7 & 445 & 43 & 47 \\
\hline F & $1,40 \mathrm{NS}$ & $1,29 \mathrm{NS}$ & $0,70 \mathrm{NS}$ & $0,13 \mathrm{NS}$ & $1,56 \mathrm{NS}$ \\
$\mathrm{dms}(5 \%)$ & 3,63 & 2,73 & 161,61 & 14,10 & 12,86 \\
CV(\%) & 22,80 & 20,41 & 19,03 & 17,59 & 15,80 \\
\hline
\end{tabular}

\section{LEGENDA :}

$$
\begin{array}{ll}
\mathrm{T} 1=\text { Testemunha } & \mathrm{T} 5=50 \% \text { calc. dolomítico }+50 \% \text { calc. calcítico } \\
\mathrm{T} 2=\text {. Calcário dolomítico } & \mathrm{T} 6=2 / 3 \text { calc. dolomítico }+1 / 3 \text { calc. calcítico } \\
\mathrm{T} 3=\text { Calcário calćtico } & \mathrm{T} 7=75 \% \text { calc. dolomítico }+25 \% \text { gesso } \\
\mathrm{T} 4=\text { Calcário magnesiano } &
\end{array}
$$


TABELA 35- Teores de micronutrientes (mg. $\mathrm{Kg}^{-1}$ ) em folhas da laranjeira Hamlin (2a. época de colheita - safra 1993/94)

\begin{tabular}{cccccc}
\hline & \multicolumn{5}{c}{$\mathrm{mg} \cdot \mathrm{kg}^{-1}$} \\
TRATAMENTO & $\mathrm{B}$ & $\mathrm{Cu}$ & $\mathrm{Fe}$ & $\mathrm{Mn}$ & $\mathrm{Zn}$ \\
\cline { 2 - 6 } T2 & 65 & 1 & 199 & 45 & 48 \\
T3 & 64 & 2 & 228 & 52 & 60 \\
T4 & 65 & 2 & 195 & 54 & 62 \\
T5 & 59 & 2 & 211 & 48 & 59 \\
T6 & 68 & 1 & 188 & 48 & 54 \\
T7 & 66 & 2 & 190 & 49 & 57 \\
F & $1,05 \mathrm{NS}$ & $3,70 \mathrm{NS}$ & $1,84 \mathrm{NS}$ & $0,82 \mathrm{NS}$ & $1,50 \mathrm{NS}$ \\
$\mathrm{dms}(5 \%)$ & 15,50 & 1,00 & 46,85 & 14,97 & 17,05 \\
CV(\%) & 13,54 & 25,26 & 12,66 & 16,61 & 16,35 \\
\hline
\end{tabular}

LEGENDA :
$\mathrm{T} 1=$ Testemunha $\mathrm{T} 5=50 \%$ calc. dolomítico $+50 \%$ calc. calcítico
$\mathrm{T} 2$ = .Calcário dolomítico $\mathrm{T} 6=2 / 3$ calc. dolomítico $+1 / 3$ calc. calcítico
$\mathrm{T} 3$ = Calcário calcítico $\mathrm{T} 7=75 \%$ calc. dolomítico $+25 \%$ gesso
T4 = Calcário magnesiano 
contrariam algumas observações feitas por QUAGGIO (1991), sobre os efeitos negativos da calagem afetando os teores foliares de micronutrientes.

Numa primeira análise da situação, este fato parece um pouco estranho, pois sabe-se da literatura que um dos efeitos diretos da calagem é a elevação do valor $\mathrm{pH}$ do solo, ocorrendo várias reações de complexação, precipitação e adsorção, reduzindo consequentemente a atividade dos micronutrientes no solo.

Por outro lado, há que se levar em consideração, neste trabalho, duas situações. A primeira é que os valores $\mathrm{pH}$ do solo não variaram significativamente em função dos tratamentos aplicados; a segunda, que provavelmente esteja associada à primeira, refere-se aos consideráveis teores de matéria orgânica existentes no solo, principalmente na camada arável e, que fatalmente influenciaram o poder tampão deste solo.

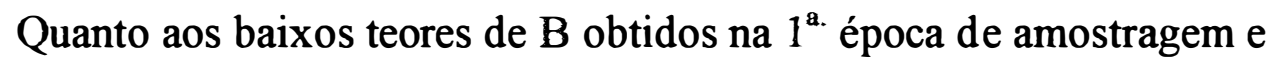
de $\mathrm{Cu}$ encontrados na $2^{\mathrm{a}}$ época, parece não inferir grandes preocupações, uma vez que suas deficiências na laranjeira, devem ser rotineiramente corrigidas através de pulverizações periódicas aplicadas em caráter curativo ou preventivo, através de tratamentos fitossanitários ou mesmo, das adubações foliares. As correções de deficiências de micronutrientes apresentados pelas plantas, normalmente não devem ser ser feitas via solo, pois são pouco eficientes e portanto, antieconômicas. 
Quando os nutrientes são aplicados nas folhas, apenas parte deles é absorvida pelas plantas. Acredita-se que a maior parte seja levada para o solo, acumulando-se nele com o passar dos anos. Na Flórida, segundo REUTHER \& SMITH $^{9}$, citado por QUAGGIO (1991), ocorre acúmulo de cobre no solo, causando toxicidade em pomares mais velhos. Essa toxidez causa a morte de radicelas e também induz à deficiência de ferro. Mantendo-se o pH do solo acima de 6,5, se evitará a ocorrência de toxidez de cobre e de alumínio e se garantirá o formecimento de cálcio e magnésio às plantas cítricas (SMITH, 1966).

\subsubsection{Dimensões físicas dos frutos}

O peso unitário em gramas e o comprimento e diâmetro em $\mathrm{mm}$ dos frutos foram mensurados e estes dados podem ser vistos nas tabelas 36 e 37 que respectivamente, são relativos à $1^{\mathrm{a} \cdot}$ e $2^{\mathrm{a} .}$ colheitas.

Os resultados dos testes estatísticos não revelaram diferenças significativas para os tratamentos aplicados em nenhuma época de avaliação, para os 3 parâmetros mensurados.

O que se observou em relação ao peso médio dos frutos foi que os valores encontrados na $2^{\mathrm{a} .}$ época foram superiores àqueles obtidos na $1^{\mathrm{a} a}$ colheita.

\footnotetext{
${ }^{9}$ REUTHER, W. \& SMTTH, P.F. Toxic effects of accumulated Cu in Florida Soils. Proceedings of the Florida State Horticultural Society, Winter Haven, 14:17-23, 1954.
} 
Tabela 36 - Dimensões fisicas determinadas nas laranjas (1a. época de colheita safra 1992/93).

\begin{tabular}{cccc}
\hline TRATAMENTO & $\begin{array}{c}\text { Peso Unitário } \\
\text { (gramas) }\end{array}$ & $\begin{array}{c}\text { comprimento } \\
(\mathrm{mm})\end{array}$ & $\begin{array}{c}\text { Diâmetro } \\
(\mathrm{mm})\end{array}$ \\
\hline T1 & 128,33 & 64,83 & 65,33 \\
T2 & 132,83 & 63,83 & 65,33 \\
T3 & 136,50 & 65,50 & 66,00 \\
T4 & 142,50 & 66,00 & 66,67 \\
T5 & 139,50 & 65,50 & 66,33 \\
T6 & 133,00 & 64,83 & 65,67 \\
T7 & 139,00 & 65,83 & 65,77 \\
\hline F & $1,04 \mathrm{NS}$ & $0,99 \mathrm{NS}$ & $0,43 \mathrm{NS}$ \\
$\mathrm{dms}(5 \%)$ & 21,26 & 3,34 & 3,43 \\
CV(\%) & 8,59 & 2,82 & 2,86 \\
\hline
\end{tabular}

\section{LEGENDA:}

$\mathrm{T} 1=$ Testemunha

$\mathrm{T} 2=$.Calcário dolomítico

$\mathrm{T} 3=$ Calcário calcítico

T4 = Calcário magnesiano
$\mathrm{T} 5=50 \%$ calc. dolomítico $+50 \%$ calc. calcítico

$\mathrm{T} 6=2 / 3$ calc. dolomítico $+1 / 3$ calc. calcítico

$\mathrm{T} 7=75 \%$ calc. dolomítico $+25 \%$ gesso 
Tabela 37 - Dimensões físicas determinadas nas laranjas (2a. época de colheita safra 1993/94).

\begin{tabular}{cccc}
\hline TRATAMENTO & $\begin{array}{c}\text { Peso Unitário } \\
\text { (gramas) }\end{array}$ & $\begin{array}{c}\text { comprimento } \\
(\mathrm{mm})\end{array}$ & $\begin{array}{c}\text { Diâmetro } \\
(\mathrm{mm})\end{array}$ \\
\hline T1 & 156,34 & 69,66 & 68,75 \\
T2 & 161,84 & 70,31 & 69,55 \\
T3 & 163,48 & 70,70 & 69,45 \\
T4 & 165,72 & 71,56 & 71,31 \\
T5 & 159,96 & 70,55 & 69,53 \\
T6 & 157,77 & 70,05 & 69,18 \\
T7 & 158,01 & 70,39 & 69,43 \\
\hline F & $0,61 \mathrm{NS}$ & $1,16 \mathrm{NS}$ & $1,06 \mathrm{NS}$ \\
dms(5\%) & 19,34 & 2,44 & 3,47 \\
CV(\%) & 6,62 & 1,90 & 2,74 \\
\hline
\end{tabular}

\section{LEGENDA:}

$\mathrm{T} 1=$ Testemunha

$\mathrm{T} 2=$.Calcário dolomítico

$\mathrm{T} 3=$ Calcário calcítico

T4 = Calcário magnesiano
$\mathrm{T} 5=50 \%$ calc. dolomítico $+50 \%$ calc. calcítico

$\mathrm{T} 6=2 / 3$ calc. dolomítico $+1 / 3$ calc. calcítico

$\mathrm{T} 7=75 \%$ calc. dolomítico $+25 \%$ gesso 
Considerando que a produtividade (t/ha) da laranja na $1^{\text {a. }}$ colheita (tabela 40 ) foi maior que na $2^{\text {a. }}$ colheita (tabela 41), conclui-se que o número total de frutos obtidos na $1^{\text {a. }}$ safra foi maior, mas as características externas dos frutos colhidos na $2^{\text {a. }}$ safra, quanto ao tamanho e vigor foram muito superiores, o que representa uma importante característica comercial, principalmente quando os frutos são comercializados "in natura". Em média, os frutos colhidos na $2^{\text {a. }}$ safra pesaram individualmente cerca de 24,50 gramas a mais do que os produzidos na $1^{\text {a. }}$ safra.

As determinações dos parâmetros de comprimento e diâmetro médios dos frutos, avaliados nas 2 safras, mostraram que as laranjas produzidas na $2^{\mathrm{a} .}$ safra foram maiores do que as produzidas na $1^{\mathrm{a} \cdot}$ safra.

Ainda, com relação ao peso médio dos frutos, embora não tenham existido diferenças significativas entre a testemunha e o tratamento $T_{4}$ (aplicação de 3,55 t/ha de calcário magnesiano) ao nível de 5\% de probabilidade, observouse diferenças de 14,17 gramas e 9,38 gramas, na $1^{\text {a. }}$ e $2^{\text {a. }}$ colheitas,

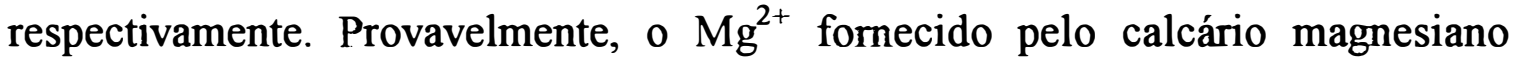
tenha proporcionado esses acréscimos no peso dos frutos. Resultados semelhantes sobre respostas dos citros à aplicação de $\mathrm{Mg}^{2+}$ foram obtidos por $\mathrm{CAMP}^{10} \mathrm{e}$ $\mathrm{KOO}^{8}$, citados por QUAGGIO (1991), tendo associado a obtenção da máxima produtividade da cultura a teores de $\mathrm{Mg}^{2+}$ no solo, superiores a $0,8 \mathrm{meq} / 100 \mathrm{~cm}^{3} \mathrm{e}$, teores nas folhas acima de $0,15 \%$, mostrando a tendência de estabilização da

\footnotetext{
${ }^{10}$ CAMP, A.F. Magnesium in cirns fertilization in Florida. Soil Science, Batimore, 63:43-52, 1947.
} 
produção quando os teores de nutriente nas folhas atingiram $0,3 \%$. Outros estudos realizados por SPENCER \& WANDER ${ }^{7}$ e $\mathrm{KOO}^{8}$, também citados por QUAGGIO (1991), mostraram que a produtividade da planta foi maximizada somente quando os teores de $\mathrm{Mg}^{2+}$ nas folhas atingiram valores entre 0,3 e $0,4 \%$.

\subsubsection{Qualidades tecnológicas dos frutos}

Os resultados das análises qualitativas do suco da laranja quanto a \% de suco, \% acidez, teor de sólidos solúveis e ratio, são apresentados nas tabelas 38 e 39 e referem-se a $1^{\text {a. }}$ e $2^{\text {a. }}$ colheitas, respectivamente.

Os tratamentos aplicados na cultura não apresentaram diferenças significativas ao nível de $5 \%$ de probabilidade, para nenhum dos parâmetros analisados na $2^{\text {a. }}$ época de colheita. $\mathrm{Na} 1^{\mathrm{a}}$. época de colheita houve diferenças significativas a $5 \%$ de probabilidade entre os tratamentos $T_{1}$ e $T_{4}$, apenas para a $\%$ de suco. A \% de suco obtida na testemunha foi significativamente maior àquela obtida para o tratamento $T_{4}$ (aplicação de 3,55 t/ha de calcário magnesiano). Nenhum dos demais tratamentos diferiram entre si e nem da própria testemunha. Esta constatação é estranha, e portanto dificil de ser explicada. Na $2^{\text {a. }}$ época de colheita, este fato não se repetiu e nenhum dos tratamentos diferiram entre si.

As laranjas produzidas na $1^{\mathrm{a} .}$ safra apresentaram menores $\%$ de suco, porém maiores teores de sólidos solúveis e ratio. As laranjas foram colhidas 
TABELA 38 - Resultados das análises qualitativas do suco das laranjas (1a. época de colheita - safra 1992/93).

\begin{tabular}{ccccc}
\hline TRATAMENTO & SUCO $^{(1)}$ & ACIDEZ $^{(2)}$ & BRIX $^{(3)}$ & RATIO $^{(4)}$ \\
\hline T1 & $51,54 a$ & 0,75 & 10,58 & 14,20 \\
T2 & $47,20 a b$ & 0,73 & 10,42 & 14,30 \\
T3 & $48,54 a b$ & 0,72 & 10,17 & 13,76 \\
T4 & $46,52 b$ & 0,71 & 9,92 & 14,11 \\
T5 & $47,85 a b$ & 0,74 & 10,33 & 14,11 \\
T6 & $47,05 a b$ & 0,72 & 10,08 & 14,03 \\
T7 & $46,85 a b$ & 0,65 & 9,83 & 15,17 \\
\hline F & $2,51^{*}$ & 1,23 NS & 0,63 NS $^{*}$ & 0,47 NS \\
dms(5\%) & 4,85 & 0,12 & 1,51 & 2,86 \\
CV(\%) & 5,56 & 9,49 & 8,15 & 11,06 \\
(1) $=$ \% de suco; ${ }^{(2)}=$ \% de ácido cítrico; ${ }^{(3)}=$ teor de sólidos solúveis; ${ }^{(4)}=$ relação:
\end{tabular}

brix/acidez

Médias seguidas de mesmas letras minúsculas, na vertical, não deferem estatisticamente pelo teste de Tukey a $5 \%$.

LEGENDA :
$\mathrm{T} 1=$ Testemunha
$\mathrm{T} 5=50 \%$ calc. dolomítico $+50 \%$ calc. calcítico
$\mathrm{T} 2$ = .Calcário dolomítico
$\mathrm{T} 6=2 / 3$ calc. dolomítico $+1 / 3$ calc. calcítico
$\mathrm{T} 3$ = Calcário calcítico
$\mathrm{T} 7=75 \%$ calc. dolomítico $+25 \%$ gesso
T4 = Calcário magnesiano 
TABELA 39 - Resultados das análises qualitativas do suco das laranjas (2a. época de colheita - safra 1993/94) .

\begin{tabular}{|c|c|c|c|c|}
\hline TRATAMENTO & $\mathrm{SUCO}^{(1)}$ & $\mathrm{ACIDEZ}^{(2)}$ & BRIX $^{(3)}$ & RATIO $^{(4)}$ \\
\hline T1 & 57,04 & 0,70 & 8,41 & 11,96 \\
\hline $\mathrm{T} 2$ & 57,32 & 0,71 & 9,16 & 12,95 \\
\hline $\mathrm{T} 3$ & 54,62 & 0,68 & 9,08 & 13,23 \\
\hline $\mathrm{T} 4$ & 58,57 & 0,66 & 8,33 & 12,67 \\
\hline T5 & 56,43 & 0,69 & 7,83 & 11,33 \\
\hline T6 & 56,93 & 0,68 & 8,16 & 11,90 \\
\hline $\mathrm{T} 7$ & 58,61 & 0,75 & 8,91 & 11,82 \\
\hline F & $0,98 \mathrm{NS}$ & $0,81 \mathrm{NS}$ & $1,78 \mathrm{NS}$ & $1,43 \mathrm{NS}$ \\
\hline $\mathrm{dms}(5 \%)$ & 6,09 & 0,13 & 1,68 & 2,57 \\
\hline $\mathrm{CV}(\%)$ & 5,86 & 10,88 & 10,80 & 11,50 \\
\hline \multicolumn{5}{|c|}{$\overline{(1)}=\%$ de suco; ${ }^{(2)}=\%$ de ácido cítrico; ${ }^{(3)}=$ teor de sólidos solúveis; ${ }^{(4)}=$ relação: } \\
\hline \multicolumn{5}{|l|}{ LEGENDA } \\
\hline $\mathrm{T} 1=$ Testemunha & & \multicolumn{3}{|c|}{$\mathrm{T} 5=50 \%$ calc dolomítico $+50 \%$ calc calcítico } \\
\hline $\mathrm{T} 2=$. Calcário dolo & & \multicolumn{3}{|c|}{$\mathrm{T} 6=2 / 3$ calc. dolomítico $+1 / 3$ calc. calcítico } \\
\hline $\mathrm{T} 3=$ Calcário calcí & & \multicolumn{3}{|c|}{$\mathrm{T} 7=75 \%$ calc. dolomítico $+25 \%$ gesso } \\
\hline
\end{tabular}


no momento adequado, pois o ratio ideal deve estar em torno de 12,00 . A $\%$ de ácido cítrico praticamente não variou entre as 2 safras.

O calcário e gesso aplicados na cultura não proporcionaram aumentos significantes em nenhum dos parâmetros analisados, dentro de uma mesma época de colheita. Estes resultados, contrariam as observações feitas por

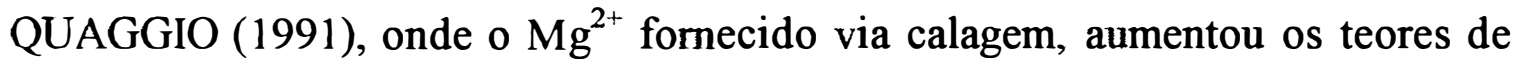
sólidos solúveis e a acidez do suco. Em cana-de-açúcar, MARTINS (1991) e ROLIM (1995), não observaram influências dos corretivos e do gesso na qualidade da matéria prima (pol \% cana, fibra \% cana e pureza). Em trabalho recente de DONADIO et al. (1994) sobre o uso exclusivo do gesso e de misturas deste produto com calcário dolomítico em laranjeira Pêra, durante 10 anos, observaram que a qualidade do fruto, no geral foi muito pouco afetada.

\subsubsection{Produtividade da cultura.}

Os resultados da produtividade da cultura da laranja em caixas/planta e t/ha, obtidos na $1^{\text {a. }}$ e $2^{\text {a. }}$ safras, são apresentados nas tabelas 40 e 41 , respectivamente.

$\mathrm{Na} 1^{\text {a. }}$ colheita, não houve efeito significativo das produções para nenhum dos tratamentos aplicados, mas a média geral da produção de laranja por planta do experimento, naquela safra (1992/93), foi de 4,87 caixas/planta. Houve 
TABELA 40 - Produtividades de laranja em caixas/planta e em t/ha (1a. época de colheita - safra 1992/93)

\begin{tabular}{|c|c|c|}
\hline TRATAMENTO & CAIXAS $^{(1)} /$ PLANTA & $\mathrm{T} / \mathrm{HA}$ \\
\hline $\mathrm{T} 1$ & 4,87 & 35,55 \\
\hline $\mathrm{T} 2$ & 4,95 & 36,09 \\
\hline T3 & 4,92 & 35,88 \\
\hline $\mathrm{T} 4$ & 4,74 & 34,58 \\
\hline T5 & 4,94 & 36,06 \\
\hline T6 & 4,73 & 35,34 \\
\hline $\mathrm{T} 7$ & 4,93 & 35,96 \\
\hline $\mathrm{F}$ & $0,18 \mathrm{NS}$ & $0,11 \mathrm{NS}$ \\
\hline $\operatorname{dms}(5 \%)$ & 0,98 & 7,23 \\
\hline CV $(\%)$ & 11,12 & 11,32 \\
\hline \multicolumn{3}{|c|}{$\overline{(1)}=$ Caixas de $40,8 \mathrm{~kg}$ (peso padrão) } \\
\hline \multicolumn{3}{|l|}{ LEGENDA: } \\
\hline $\mathrm{T} 1=$ Testemunha & \multicolumn{2}{|c|}{$\mathrm{T} 5=50 \%$ calc. dolomítico $+50 \%$ calc calcítico } \\
\hline $\mathrm{T} 2=$. Calcário dolomítico & \multicolumn{2}{|c|}{$\mathrm{T} 6=2 / 3$ calc. dolomítico $+1 / 3$ calc. calcítico } \\
\hline T3 = Calcário calć́tico & \multicolumn{2}{|c|}{$\mathrm{T} 7=75 \%$ calc . dolomítico $+25 \%$ gesso } \\
\hline
\end{tabular}


TABELA 41 - Produtividades de laranja em caixas/planta e em t/ha (2a. época de colheita - safra 1993/94)

\begin{tabular}{ccc}
\hline TRATAMENTO & CAIXAS $^{(1)}$ /PLANTA & T/HA \\
\hline T1 & $4,18 b$ & $30,45 b$ \\
T3 & $4,75 a b$ & $35,33 a b$ \\
T4 & $4,66 a b$ & $33,96 a b$ \\
T5 & $4,48 a b$ & $32,69 a b$ \\
T6 & $4,60 a b$ & $33,55 a b$ \\
T7 & $4,51 a b$ & $32,88 a b$ \\
F & $4,94 a$ & $36,00 a$ \\
dms(5\%) & $2,13^{*}$ & $2,56^{*}$ \\
CV(\%) & 0,72 & 5,10 \\
\hline (1) Caixas de 40,8 kg (peso padrão) & 8,68 & 8,35 \\
\hline
\end{tabular}

Médias seguidas de mesmas letras minúsculas, na vertical, não diferem estatisticamente pelo teste de Tukey a $5 \%$.

\section{LEGENDA:}

$\mathrm{T} 1=$ Testemunha

$\mathrm{T} 2=$.Calcário dolomítico

$\mathrm{T} 3=$ Calcário calcítico

$\mathrm{T} 4$ = Calcário magnesiano
$\mathrm{T} 5=50 \%$ calc. dolomítico $+50 \%$ calc. calcítico

$\mathrm{T} 6=2 / 3$ calc. dolomítico $+1 / 3$ calc. calcítico

$\mathrm{T} 7=75 \%$ calc. dolomítico $+25 \%$ gesso 
um acréscimo de 0,74 caixas/planta em relação à média geral de produção obtida pela Fazenda Colorado (4,13 caixas/planta), na mesma safra.

$\mathrm{Na} 2^{\mathrm{a} .}$ colheita, a aplicação da mistura de 2,95ha de calcário dolomítico +1 t/ha de gesso, diferiu significativamente da testemunha, apresentando um acréscimo na produtividade da ordem de 5,55 t/ha. Os demais tratamentos aplicados não influenciaram as produtividades. Estes resultados são também apresentados na figura 8 , na forma de histograma, a fim de evidenciar os incrementos obtidos nas produtividades das 2 safras (1992/93 e 1993/94).

Estes resultados confirmam as recomendações de VITTI (1987), MALAVOLTA (1983) e PAVAN et al. (1984) quanto ao uso da mistura de gesso com calcário dolomítico sem incorporação profunda a fim de se reduzir a concentração de $\mathrm{Al}^{3+}$ tóxico em subsuperfície, devido a ação eficaz do gesso em profundidade, para se obter incrementos na produtividade.

O acréscimo na produção de laranja em 0,76 caixas/planta ou $18 \%$, obtido pela mistura de calcário dolomítico + gesso, em relação à testemunha (safra 1993/94) é concordante com resultados obtidos por DONADIO et al. (1994) sobre aumentos de produção de laranja obtidos com aplicação isolada de calcário e aplicação da mistura de calcário + gesso. Estes pesquisadores observaram que nas safras 91 a 93, a aplicação isolada de calcário e a mistura de calcário + gesso (50:50), produziram em média 1 caixa/planta a mais em relação à aplicação isolada de gesso e, 0,5 caixas/planta a mais em relação à testemunha. 
PRODUTIVIDADES DE LARANJA HAMLIN (t/ha)

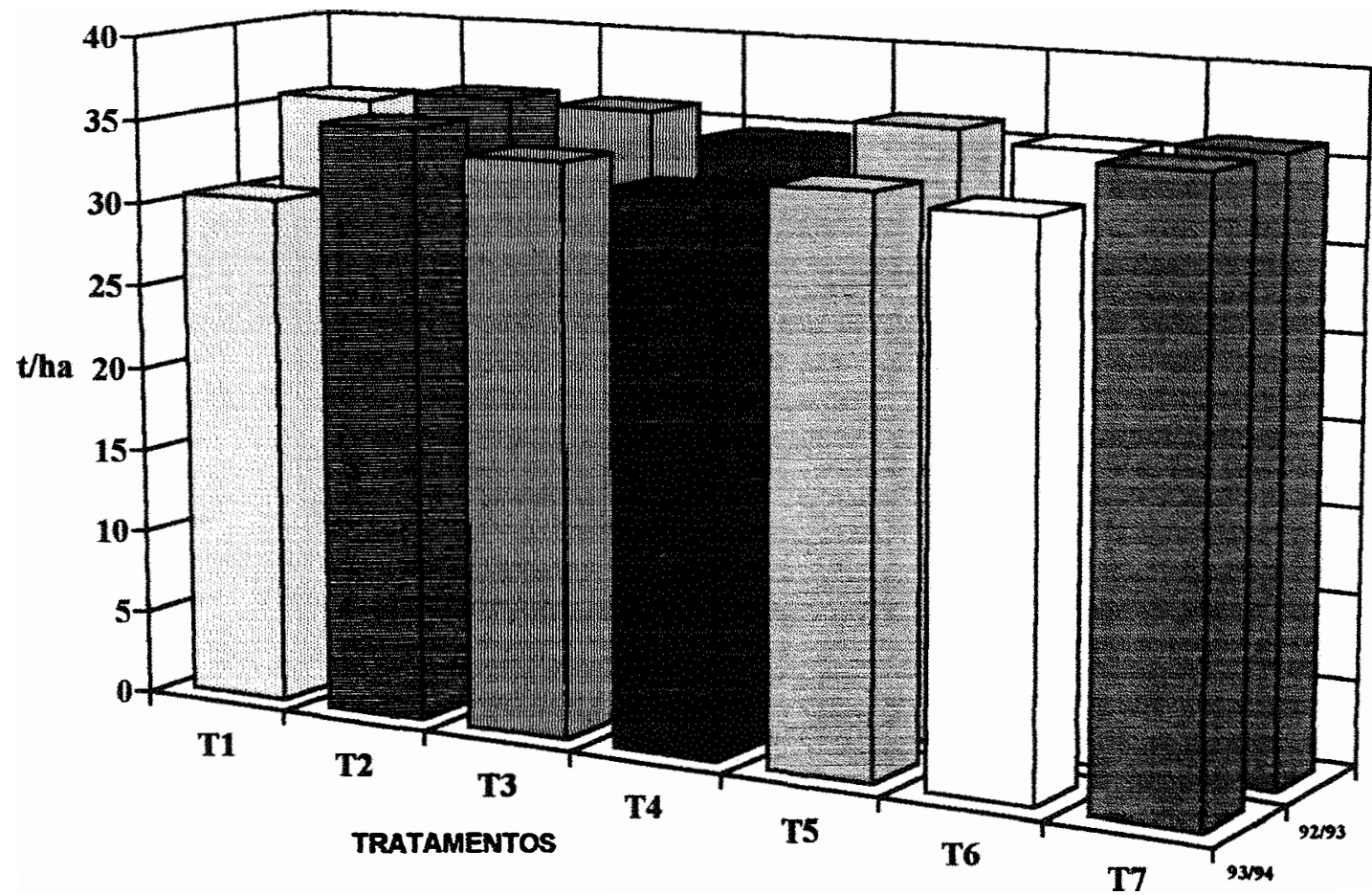

LEGENDA :

$\mathrm{T} 1=$ Testemunha

$\mathrm{T} 2=$ Calcário dolomítico

$\mathrm{T} 3$ = Calcário calcítico

$\mathrm{T} 4$ = Calcário magnesiano

T5 $=50 \%$ de calcário dolomítico $+50 \%$ de calcário calcítico

$\mathrm{T} 6=2 / 3$ de calcário dolomítico $+1 / 3$ de calcário calcítico

$\mathrm{T} 7=75 \%$ de calcário dolomítico $+25 \%$ de gesso

Figura 8. Produtividades de laranja Hamlin em $t / h a$, obtidas na $1^{\mathrm{a}}$ e $2^{\mathrm{a}}$ épocas de colheita (safras 1992/93 e 1993/94). 
Observaram também que os efeitos positivos do calcário ou da alta exigência dos citros em $\mathrm{Ca}^{2+}$, ou ainda pelo uso do gesso, que enriquece o perfil do solo em $\mathrm{Ca}^{2+}$ e diminuiu a saturação por $\mathrm{Al}^{3+}$, provavelmente, sejam os responsáveis diretos pelos incrementos obtidos nas produtividades.

Na literatura, há poucos trabalhos sobre a cultura da laranja que procuraram obter a máxima produtividade usando corretivos em doses crescentes, a fim de se obter uma correlação estreita entre o valor $\mathrm{pH}$, saturação por bases e produtividade. Dentre eles, QUAGGIO (1991), obteve resposta acentuada da laranja valência à calagem. atingindo a produtividade máxima, quando os valores de saturação por bases ficaram ao redor de $60 \%$, na camada arável do solo. GUEST \& CHAPMAN (1994), também obtiveram melhores produtividades dos citros quando a calagem aumentou a disponibilidade de nutrientes e o $\mathrm{pH}$ atingiu a faixa de 5,5 a 6,0 .

Parece haver concenso entre os pesquisadores de que a ausência da calagem em citros resulta em perda de longevidade da cultura e se agrava mais com as progressivas perdas de produtividade. O levantamento realizado por ROSSETO et al. (1988) sobre a utilização da calagem em citros no Estado de São Paulo, resume muito bem esta situação ao citar que $57,5 \%$ dos 1321 pomares amostrados não tinham recebido calcário nos últimos 3 anos e $68 \%$ deles, tiveram suas produtividades iguais ou inferiores a 2 caixas/planta. 
Em outras culturas, há trabalhos que mostram os efeitos positivos da calagem e gessagem sobre a produtividade das culturas. Dentre eles, VITTI \& MALAVOLTA (1985), citaram os efeitos positivos da aplicação de gesso como fonte de enxofre em trabalhos desenvolvidos por vários pesquisadores, em várias culturas, indicando nesses trabalhos, a dose de 15 a $50 \mathrm{~kg} / \mathrm{ha}$ de $\mathrm{S}(100$ a 350 $\mathrm{kg} / \mathrm{ha}$ de gesso) como suficientes para as culturas atingirem boas produtividades. As maiores doses foram indicadas para solos arenosos e pobres em matéria orgânica.

Trabalhos desenvolvidos recentemente no Estado de São Paulo sobre os efeitos da calagem e ou gessagem em cana-de-açúcar, também relataram incrementos na produtividade. Assim, MAZZA (1993) observou que a aplicação de doses e misturas de calcário e gesso foram efetivas em elevar a produtividade da cultura nos 3 cortes, sendo que o gesso apresentou maior capacidade de elevar a produtividade da cultura a curto e médio prazos ( $1^{0}$ e $2^{0}$ cortes), enquanto o calcário foi mais eficiente em prolongar seus efeitos a longo prazo. Nesse sentido, ROLIM (1995), também observou que a aplicação de corretivos e gesso, com exceção da magnesita, promoveram um aumento da longevidade do canavial até o $3^{\circ}$ corte sendo que a mistura de gesso $(85 \%)+$ magnesita $(15 \%)$ se destacou dentre todos os tratamentos, em todos os cortes, produzindo o dobro da testemunha na $2^{\mathrm{a} .}$ soqueira. 
Desta forma, fica evidente a eficácia relativa do calcário e gesso sobre a produtividade das culturas mas, de acordo com RAIJ et al. (1982), tem-se que tomar alguns cuidados na recomendação destes produtos, pois doses elevadas de calcários aplicados em solos com camadas subsuperficiais muito ácidas podem reduzir sensivelmente a acidez, como também podem provocar desequilíbrios no complexo sistema coloidal do solo e afetar direta e negativamente a produtividade das culturas. 


\section{CONCLUSÕES}

Nas condições experimentais em que esse trabalho foi realizado e, de acordo com os resultados obtidos, pode-se concluir que:

a) Houve resposta significativa na produtividade da laranja Hamlin à aplicação da mistura de calcário dolomítico e gesso $(75 \%+25 \%)$, nas doses de 2,96 t/ha e $1 \mathrm{t} / \mathrm{ha}$, respectivamente, na $2^{\text {a. }}$ colheita (safra 1993/94);

b) As doses de 2,96;2,86 e 3,55 t/ha de calcário dolomítico, calcítico e magnesiano, respectivamente, aplicados isoladamente, bem como as misturas de calcário dolomítico com calcário calcítico, nas proporções de $(50 \%+50 \%)$ e $(2 / 3+$ 1/3), não apresentaram incrementos significativos nas produtividades da laranja Hamlin, até a $2^{\text {a. }}$ colheita;

c) Os corretivos aplicados isoladamente e as misturas de corretivos e de gesso não influenciaram os teores de macro e micronutrientes na folha e nem a qualidade da laranja, quanto aos parâmetros: \% suco, \% acidez, teor de sólidos solúveis e ratio;

d) Os tratamentos não diferiram quanto ao peso unitário (g), comprimento (mm) e diâmetro ( $\mathrm{mm})$ do fruto, nas duas safras, mas as características 
externas (vigor e aparência) da laranja colhida na $2^{\text {a. }}$ safra foi muito superior. Estas características são importantes para a comercialização do produto "in natura".

e) Houve lixiviação de $\mathrm{S}_{-} \mathrm{SO}_{4}{ }^{2-}$ em subsuperficie $(20-60 \mathrm{~cm})$, aos 24 meses após a aplicação da mistura de calcário dolomítico + gesso nas doses de $2,95 \mathrm{t} / \mathrm{ha}$ e $1 \mathrm{t} / \mathrm{ha}$, respectivamente.

Este trabalho de pesquisa integra-se ao Projeto: Calcário e Gesso (convênio: Dolomia/Solorrico/ESALQ/FEALQ), com mais 2 unidades experimentais instaladas em áreas comerciais. Estes experimentos deverão ter continuidade nos anos subsequentes a fim de se obter novas informações, principalmente, sobre os efeitos residuais do calcário e gesso aplicados no solo e suas possíveis influências sobre a planta. 


\section{REFERÊNCIAS BIBLIOGRÁFICAS}

ALCARDE, J.C. Características de qualidade dos corretivos da acidez do solo. In: Simpósio sobre acidez e calagem, XV Reunião Brasileira de Fertilidade do Solo, Campinas, 1983, p. 11-22.

ALCARDE, J.C. Contraditória, confusa e polêmica; é a situação do uso do gesso na agricultura. Informačões agronômicas POTAFÓS, Piracicaba, (41):1-3, 1988.

ALCORDO, I.S \& RECHCIGL, L.E. Phosphogypsun in agriculture; a review. Advances in agronomy, New York, 49:55-119, 1993.

BARRETO, A.C. Efeito de sistemas de rotação, sucessão e níveis de calagem, sobre características fisicas e químicas do solo e no desenvolvimento do sistema radicular e produção de grãos de milho (Zea mays L.). Piracicaba, 1991. 154p. (Doutorado - Escola Superior de Agricultura "Luiz de Queiroz"-USP).

BORKERT, C.M.; PAVAN, M.A.; LANTMANN, A.F. Considerações sobre o uso do gesso na agricultura. Informações Agronômicas POTAFÓS, Piracicaba, (40): 1-3, 1987. 
CAMARGO, AP Influência da granulometria de três materiais corretivos na neutralização da acidez do solo. Piracicaba, 1972. 59p. (Mestrado - Escola Superior de Agricultura “Luiz de Queiroz”-USP).

CARVALHO, M. da C.S. Sulfato de cálcio, fosfogesso e carbonato de cálcio na melhoria do ambiente radicular de subsolos ácidos. Piracicaba, $1994.84 \mathrm{p}$. (Mestrado - Escola Superior de Agricultura “Luiz de Queiroz"-USP).

COHEN, A. Fertilization de los cítricos. Berna, Instituto Internacional de la Potasa, 1983. $48 \mathrm{p}$.

COLEMAN, N.T., KAMPRATH, R.J., WEED, S.D. Liming. Advances in Agronomy, New York, 10:475-522, 1958.

CHANDLER, W.H. Evergreen orchards. 2nd ed. London, Henry Kimpton, 1958. p. 101-103.

CHAPMAN, H.D. The mineral nutrition of citrus. In: REUTHER, W.; BATCHELOR, L.D.; WEBBER, H.J., eds The citrus industry. Berkeley, University of California, 1968. v.2, chap. 3, p. 127-289.

DEMATTÊ, J.L.I. Caracteristics of Brasilian soils related to root growth In: RUSSEL, R.S. et al., ed. The soil root system in relation to Brazilian agriculture. Londrina, IAPAR, 1981. p. 21-41

DONADIO, L.C.; VITTI, G.C.; SEMPIONATO, O.R.; PARO, M. Gessagem isolada prejudica citros. Informativo coopercitrus EECB, Bebedouro, p. 16, 1984. 
EMBRAPA/CPAC. Planaltina. Rel. tec. anu. Cerrados. Planaltina, 1981, v.1, $190 \mathrm{p}$.

EMBRAPA/CPAC. Planaltina. Rel. tec. anu. Cerrados. Planaltina, 1982. v.6, $163 \mathrm{p}$.

FAGERIA, N.K. Adubação e nutrição mineral da cultura do arroz. Campos, 1984. $341 \mathrm{p}$.

FAO. Rome. Statistics séries $\mathrm{n}^{\mathrm{0}} 89$, vol. 38, 1990, $121 \mathrm{p}$.

FOY, C.D. Physiological effects of hidrogen, aluminum and manganese toxicities in acid soils. In: ADAMS, F., ed. Soil acidity and liming. 2nd ed. Madison, ASA, 1984. p. 57-98.

FREITAS, J.A.D. Efeito residual do calcário na distribuição vertical de nutrientes em um oxisol muito argiloso da Amazônia. In: CONGRESSO BRASILEIRO DE CIÊNCIA DO SOLO, 21, Campinas, 1987. Resumos. Campinas, 1987. $232 \mathrm{p}$.

FREITAS, L.M.M. \& RAIJ, B. van. Efeitos residuales delencalado de um latossol en São Paulo, Brasil. In: BORNEMISSA, E. \& ALVARADO, A. ed. Manejo de suelos en la America Tropical. Raleigh, North Carolina State Univesity, 1974, p. 304-312.

FURLANI, P.R. \& BERTON, R.S. Atividade de cálcio e alumínio e desenvolvimento radicular. In: SEMINÁRIO SOBRE O USO DO GESSO 
NA AGRICULTURA, 2., Uberaba, 1992. Anais. Uberaba, IBRAFOS, 1992. v.1., p. 121-138.

GARGANTINI, $\mathrm{H}$. Efeitos da granulometria, forma e quantidades de materiais corretivos na acidez do solo. Bragantia, Campinas, 33(9):87-96, 1974.

G.P.A.C.C. - GRUPO PAULISTA DE ADUBAÇÃO E CALAGEM PARA CITROS. Recomendações de adubação e calagem para citros no Estado de São Paulo. Laranja. Cordeirópolis, 11(3):1-14, 1990.

GUEST, P.L. \& CHAPMAN, H.D. Some effects of $\mathrm{pH}$ on the growth of citrus in sand and solution cultures. Soil Sci., Madison, 58:455-465, 1944.

KAMPRATH, E.J. Exchangeable aluminum as a criterion for liming leached mineral soils. Soil Science Society of American Proceedings, Madison, 34:252-254, 1970.

LOPES, A.S. A calagem no cerrado. In: XV REUNIÃO BRASILEIRA DE FERTILIDADE DO SOLO, 15., Campinas, 1982, Resumos. p. 3.

LOPES, A.S. Solos sob "cerrado"; características, propriedades e manejo. Piracicaba. POTAFOS, 1983, $162 \mathrm{p}$.

MALAVOLTA, E. Manual de química agrícola; nutrição de plantas e fertilidade do solo. São Paulo, Ceres, 1976. 528 p.

MALAVOLTA, E.; ROMERO, J.P.; LIEM, T.H.; VITTI, G.C. Gesso agrícola seu uso na adubação e correção do solo. São Paulo, Ultrafértil, 1979. 32 p. 
MALAVOLTA, E. A prática da calagem. $3^{\text {a }}$ ed. Sorocaba, Mineradora Pagliato, 1983. 43p. (Boletim téc., 2).

MALAVOLTA, E. \& VIOLANTE NETTO, A. Nutrição mineral, calagem, gessagem e adubação dos citros. Piracicaba, POTAFOS, 1989. 153 p.

MALAVOLTA, E. O gesso agrícola no ambiente e na nutrição da planta perguntas e respostas. Jaboticabal. XVI Semana de Ciências e Tecnologia Agropecuária. 1991, 29 p. (mimeografado).

MALAVOLTA, E. O gesso agrícola no ambiente e na nutrição da planta; Perguntas e Respostas. In: SEMINÁIO SOBRE O USO DO GESSO NA AGRICULTURA, 2., Uberaba, 1992. Anais. Uberaba, IBRAFOS, 1992, p. 41-66.

MARTINS, M. Efeitos da calagem na cultura da cana-de-açúcar (Saccharum spp) em solo sob vegetação de cerrado. Piracicaba, 1991. 86p. (Mestrado Escola Superior de Agricultura “Luiz de Queiroz"-USP).

MAZZA, J.A. Efeitos do calcário e gesso, aplicados em pré-plantio ou em soqueiras da cana-de-açúcar (Saccharum_spp), nos atributos químicos de solos e na produtividade agrícola da cultura. Piracicaba, 1993. 140p. (Doutorado - Escola Superior de Agricultura “Luiz de Queiroz”-USP).

MEDINA, C.C. \& BRINHOLI, O. Estudo da aplicação de gesso e calcário na produção de cana-de-açúcar (Saccharum spp), Açúcar e Álcool. Energia na Agricultura, Botucatu. 6(3): 18-22, 1991. 
OLIVEIRA, J.B. de. Solos para citros. In: RODRIGUES, O.; VIÉGAS, F.; POMPEU JR, J.; AMARO, A.A. ed. Citricultura brasileira. $2^{\text {a. }}$ ed. Campinas, Fundação Cargill, 1991 v.1., p. 198-227.

OLIVEIRA, J.B. \& BERG, M. van den. Aptidão agrícola das terras do Estado de São Paulo; quadrícula de Araras. 2. Memorial descritivo. Boletim Técnico Instituto Agronômico, Campinas, (102):1-60, 1985.

OLIVEIRA, J.B. \& ROTTA, C.L. Levantamento pedológico detalhado da Estação Experimental de Limeira, SP. Bragantia, Campinas, 32:1-60, 1973.

PAOLINELLI, N.T.; OLIVEIRA, P.M.; SANTOS, P.R.R.S.; LEANDRO, V.P.; MORAES, W.V. Aplicação direta do fosfogesso. In: SEMINÁRIO SOBRE O USO DO FOSFOGESSO NA AGRICULTURA, 1.,Brasília, 1986. Anais. Brasília, EMBRAPA/DDT, 1986, p.197-217.

PAVAN, M.A. Comportamento do gesso nos solos ácidos das regiões tropicais e subtropicais. Informações Agronômicas POTAFOS, Piracicaba, (35): 1 e 2, 1986a.

PAVAN, M.A.; BINGHAM, F.T.; PRATT, P.F. Redistribution of exchangeable calcium, magnesium and aluminum following lime os gypsum aplications to a Brasilian oxisol. Soil Sci. Soc. Amer. J., 48(1):33-38, 1984.

PAVAN, M.A. \& VOLKWEISS, S.J. Efeitos do gesso nas relações solo-planta: princípios. In: SEMINÁRIO SOBRE O USO DO FOSFOGESSO NA 
AGRICULTURA, 1., Brasília, 1986. Anais. Brasília, EMBRAPA-DDT, 1986b. p. 107-144.

QUAGGIO, J.A. Critérios para calagem em solos no Estado de São Paulo. Piracicaba, 1983. 76 p. (Mestrado - Escola Superior de Agricultura "Luiz de Queiroz"-USP).

QUAGGIO, J.A. Reação do solo e seu controle. In: DECHEN, A.R. \& CARMELLO, Q.A. de C., coord. Simpósio avancado de química e fertilidade do solo. Campinas, Fundação Cargill, 1986. p. 53-89.

QUAGGIO, J.A. Respostas das culturas à calagem. In: FUNDAÇÃO CARGILL. Seminário sobre corretivos agrícolas. Campinas, 1989. cap. 4, p. 122-157.

QUAGGIO, J.A. Respostas da laranjeira valência (Citrus Sinnensis L. Osbeck) sobre limoeiro Cravo (Citrus limonia L. Osbeck) à calagem e ao equilíbrio de bases num latossolo vermelho escuro de textura argilosa. Piracicaba, 1991. 107p. (Doutorado - Escola Superior de Agricultura "Luiz de Queiroz"-USP).

QUAGGIO, J.A. Respostas das culturas de milho e soja, à aplicação de calcário e gesso e movimento de íons em solos do Estado de São Paulo. In: SEMINÁRIO SOBRE O USO DE GESSO NA AGRICULTRUA, 2., Uberaba, 1992. Anais. Uberaba, IBRAFOS, 1992, p. 241-62. 
QUAGGIO, J.A.; MASCARENHAS, H.A.A.; BATAGLIA, O.C. Resposta da soja à aplicação de doses crescentes de calcário em latossolo roxo distrófico de cerrado; 2. Efeito residual. R. Bras. Ci. Solo, Campinas, 6:113-18, 1982.

QUAGGIO, J.A.; RAIJ, B van; GALLO, P.B.; MASCARENHAS, H.A.A. Resposta da soja à aplicação de doses de calcário e de gesso e lixiviação de bases no solo. In: CONGR. BRAS.CI. SOLO, 21, Campinas, 1987. Resumos. Campinas, CERES. 1987, 232p.

RAIJ, B. van. Avaliação da fertilidade do solo. Piracicaba, POTAFOS, 1981. $142 p$.

RAIJ, B. van. Acidez do solo e calagem. In: CURSO DE ATUALIZAÇÃO EM FERTILIDADE DO SOLO, Londrina, 1983. Trabalhos apresentados. Londrina, IAPAR, 1983. p.65-87.

RAIJ, B.van. Gesso agrícola na melhoria do ambiente radicular no subsolo. São Paulo, ANDA, 1988. $88 \mathrm{p}$.

RAIJ, B. van. Fertilidade do solo e adubação. Piracicaba, POTAFOS, 1991. $343 \mathrm{p}$.

RAIJ, B. van. Reações de gesso em solos ácidos. In: SEMINÁRIO SOBRE O USO DE GESSO NA AGRICULTURA. 2., Anais. Uberaba, IBRAFOS, 1992. p.105-19. 
RAIJ. B. van; CANTARELlA, H.;CAMARGO, A.P.; SOARES, E. Perdas de cálcio e magnésio durante cinco anos em ensaio de calagem. $\underline{\text { Revista }}$ Brasileira de Ciência do Solo, Campinas, 6(1):33-37, 1982.

RAIJ, B. van \& QUAGGIO, J.A. Uso eficiente de calcário e gesso na agricultura. In: SIMPÓSIO SOBRE FERTILIZANTES NA AGRICULTURA BRASILEIRA. Brasília, DF, 1984. Anais. Brasília, EMBRAPA, 1984, p. $323-46$

RAIJ, Bvan; QUAGGIO, J.A.; CANTARELLA, H.; FERREIRA, M.E.; LOPES, A.S. \& BATAGLIA, O.C. Análise química do solo para fins de fertilidade. Campinas, Fundação Cargill, 1987, 170 p.

RAIJ, B. van \& PEECH, M. Electrochemical properties of some oxisols and alfisols of the tropics. Soil Science Society of America Proceedings, Madison, 36(4):587-593, 1972.

RITCHEY, K.D.; SILVA, J.E.; SOUSA, D.M.G. Lixiviação de cálcio e crescimento de raizes em solos de cerrados. In: CONGRESSO BRASILEIRO DE CIÊNCIAS DO SOLO, 18., Salvador, 1981. Programa e Resumos. Salvador, SBCS, 1981. p.96.

ROLIM, J.C. Influência de corretivos da acidez e do gesso agrícola em propriedades químicas do solo, na nutrição e produção da cana-de-açúcar. Piracicaba, 1995. 116 p. (Doutorado - Escola Superior de Agricultura "Luiz de Queiroz"-USP). 
ROSSETO, J.; LORENA, B.; COUTINHO, E.L.M.; SOUZA, E.C.A.; FERREIRA, M.E.; CANTARELLA, H.; QUAGGIO, J.A.; CARMELLO, Q.A.; SILVEIRA, R.I. Projeto Produtividade; os primeiros números LARANJA \& Cia, Cordeirópolis, 11:4-5-, 1988.

SOUSA, D.M.G. de. Calagem e adubação da soja no cerrado. Informações Agronômicas - POTAFOS. Piracicaba, (47): 1-3, 1989.

SOUSA, D.M.G. de; LOBATO, E.; RITCHEY, K.D.; REIN, T.A. Respostas de culturas anuais e Leucena a gesso no cerrado. In: SEMINÁRIO SOBRE O USO DO GESSO NA AGRICULTURA, 2., Uberaba, 1992. Anais. Uberaba, IBRAFOS, 1992. p. 277-306.

SOUSA, D.M.G. de \& RITCHEY. K.D. Uso do gesso no solo de cerrado. In: SEMINÁRIO SOBRE O USO DO FOSFOGESSO NA AGRICULTURA, 1., Brasília, 1985, Anais. Brasília, EMBRAPA/DDT, 1986a. p.119-44.

SOUSA, D.M.G. de \& RITCHEY, K.D. Correção de acidez subsuperficial; uso do gesso no solo de cerrado. In: DECHEN, A.R.; CARMELLO, Q.A.C., coords. Simpósio Avançado de Química e Fertilidade do solo. Campinas, Fundação Cargill, 1986b. p. 91-113.

SMITH, P.F. Citrus nutrition. In: CHILDERS, N.F., ed. Temperate to tropical fruit nutrition. Somerset. Somerset Press, 1966. cap. 7. p. 174-207. 
SUMNER, M.E. Uso atual do gesso no mundo em solos ácidos. In: SEMINÁRIO SOBRE O USO DO GESSO NA AGRICULTURA, 2., Uberaba, 1992. Anais. Uberaba, IBRAFOS, 1992. p. 7-40.

SUMNER, M.E. Gypsum and acid soils: the world scene advances in agronomy New York, 51:1-32, 1993.

SUZUKI, A. Doses e modos de aplicação de calcário em pomar de macieira em Latossolo Húmico distrófico do Estado de Santa Catarina. Viçosa, 1989. 75p. (Mestrado - Universidade Federal de Viçosa).

VIOLANTE NETTO, A.; RAIJ, B. van; BLASCO, E.E.A.; VITTI, G.C.; CANTARELLA, H.; TEÓFILO SOBRINHO, J.; QUAGGIO, J.A.; NEGRI, J.D.; RODRIGUES, O.; BATAGLIA， O.C.; MALAVOLTA， E. $\underline{\text { Recomendações de adubação e calagem para citros no Estado de São Paulo. }}$ Cordeirópolis, Estação Experimental de Limeira, 1988. 18 p.

VITTI, G.C. Acidez e calagem do solo. Laranja, Cordeirópolis (5):77-102, 1984.

VITTI, G.C. Acidez do solo, calagem e gessagem. Ilha Solteira, UNESP, 1987. 26p.

VITTI, G.C. Avaliação e interpretação do enxofre no solo e na planta. Jaboticabal, FUNEP, 1988, 37 p.

VITTI, G.C. Calagem e adubação de citros. Piracicaba, POTAFOS, 1989a. $12 \mathrm{p}$. 
VITTI, G.C. Calagem e adubação de citros. Informações agronômicas. POTAFOS, Piracicaba, p.1-4, 1989b.

VITTI, G.C.; MAZZA, J.A.; PEREIRA, H.S.; DEMATTÊ, J.L.I. Resultados experimentais do uso de gesso na agricultura - cana-de-açúcar. In: SEMINÁRIO SOBRE O USO DO GESSO NA AGRICULTURA, 2., Uberaba, 1992. Anais. Uberaba, IBRAFOS, 1992. p. 191-224.

VITTI, G.C. \& MALAVOLTA, E. Fosfogesso; uso agrícola. In: SEMINÁRIO SOBRE CORRETIVOS AGRÍCOLAS, Piracicaba, 1983. Anais. Campinas. Fundação Cargill, 1985, cap. 5, p. 161-194.

YAMADA, T. Capacidade de adsorção máxima de sulfato do solo como parâmetro adicional na recomendação de gesso. Piracicaba, 1989. 73p. (Doutorado - Escola Superior de Agricultura “Luiz de Queiroz"-USP). 